JOSÉ LELES DE SOUZA

\title{
SOBRE A FORMA E O CONTEÚDO DA EDUCAÇÃO PARA O TRÂNSITO NO ENSINO FUNDAMENTAL
}

Tese apresentada ao Departamento de Transportes da Escola de Engenharia de São Carlos da Universidade de São Paulo para a obtenção do título de Doutor em Ciências, Programa de Pós-graduação em Engenharia de Transportes

Área de Concentração: Planejamento e Operação de Sistemas de Transportes

Orientador: Prof. Titular Antônio Clóvis Pinto Ferraz

São Carlos

2010 
AUTORIZO A REPRODUÇÃO E DIVULGAÇĀO TOTAL OU PARCIAL DESTE TRABALHO, POR QUALQUER MEIO CONVENCIONAL OU ELETRÓNICO, PARA FINS DE ESTUDO E PESQUISA, DESDE QUE CITADA A FONTE.

Ficha catalográfica preparada pela Seçāo de Tratamento da Informaçäo do Serviço de Biblioteca - EESC/USP

\begin{tabular}{|c|c|}
\hline $5729 \mathrm{~s}$ & $\begin{array}{l}\text { Souza, José Leles de } \\
\text { Sobre a forma e o conteúdo da educação para o trânsito } \\
\text { no ensino fundamental / José Leles de Souza ; orientador } \\
\text { Antônio Clovis Pinto Ferraz. -- São Carlos, } 2010 \text {. }\end{array}$ \\
\hline & $\begin{array}{l}\text { Tese (Doutorado-Programa de Pós-Graduação em } \\
\text { Engenharia de Transportes e Área de Concentração em } \\
\text { Planejamento e Operação de Sistemas de Transportes)-- } \\
\text { Escola de Engenharia de São Carlos da Universidade de São } \\
\text { Paulo, } 2010 \text {. }\end{array}$ \\
\hline & $\begin{array}{l}\text { 1. Engenharia de tráfego - educação. 2. Ensino } \\
\text { fundamental. I. Título. }\end{array}$ \\
\hline
\end{tabular}


Candidato(a): Engenheiro JOSÉ LELES DE SOUZA

Tese defendida e julgada em 26/05/2010 perante a Comissão Julgadora:

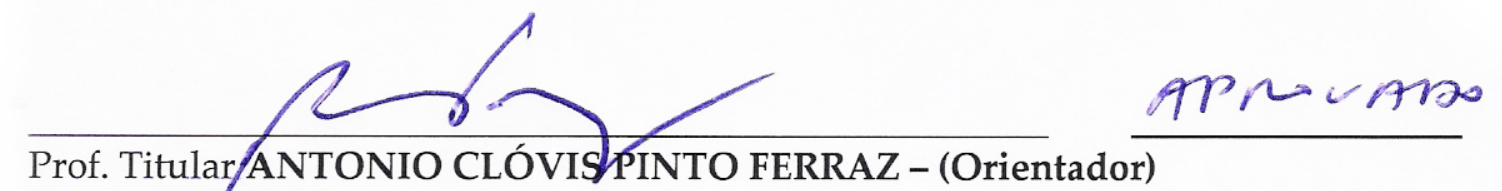

(Escola de Engenharia de São Carlos/USP)

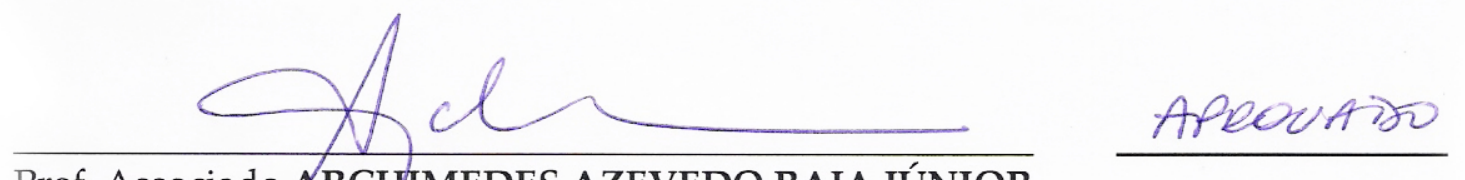

Prof. Associado ARCHIMEDES AZEVEDO RAIA JÚNIOR

(Universidade Federal de São Carlos/UFSCar)

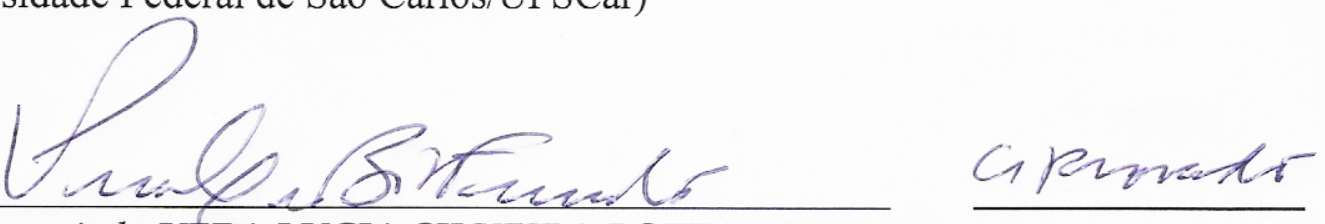

Prof ${ }^{\mathrm{a}}$. Associada VERA LUCIA SILVEIRA BOTTA FERRANTE

(Centro Universitário Æe Araraquara/UNIARA)

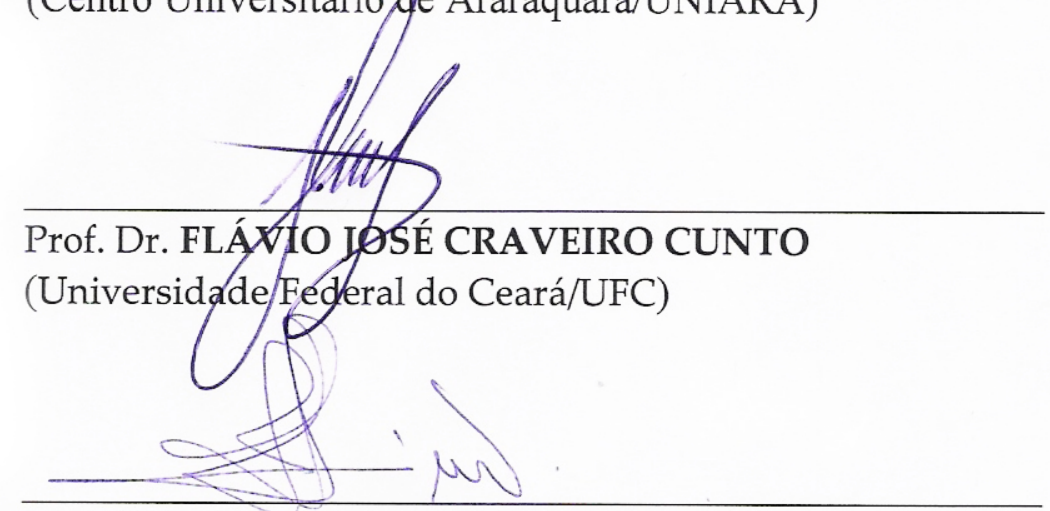

Prof ${ }^{\mathrm{a}}$. Dr ${ }^{\mathrm{a}}$. FERNANDA ANTONIO SIMÕES

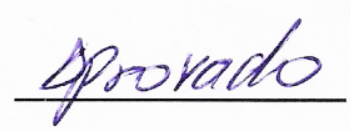

(Universidade Estadual de Maringá/UEM)

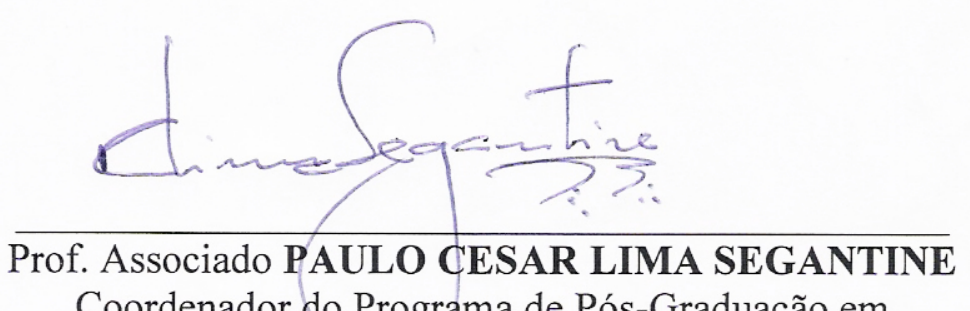

Coordenador do Programa de Pós-Graduação em

Engenharia de Transportes

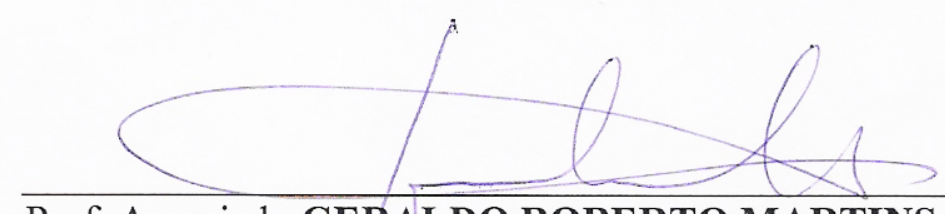

Prof. Associado GERALDO ROBERTO MARTINS DA COSTA

Presidente da Comissão da Pós-Graduação da EESC 


\section{DEDICATÓRIA}

A milhões de brasileiros que estão sendo privados do direito à educação e da educação para o trânsito, nos bancos escolares ou fora deles. Em especial, a meu pai (in memorian), à minha mãe, irmãos e irmãs, amigos, e ao movimento Shalom da Arquidiocese de Mariana - MG, pela presença marcante no meu dia a dia. 


\section{AGRADECIMENTOS}

Àqueles que, direta ou indiretamente, contribuíram para o bom êxito desta Tese.

Em especial,

Prof. Titular Doutor Antônio Clóvis “Coca” Pinto Ferraz (Orientador/USP);

Prof. Doutor Reinier Johannes A Rozestraten - in memorian - (Coorientador/UCDB);

Professores Davilson Lucato, Juciara Rodrigues, Maria Solange Félix Pereira (in memorian), pelos muitos ensinamentos e oportunidades;

Ao Instituto de Certificação e Estudos de Trânsito e Transporte, pelo apoio técnico e logístico;

Aos amigos do Projeto Rumo à Escola - em especial, à Neusa Aparecida Costa;

A todos os amigos, peças ímpares em nossa caminhada.

A Deus Pai, por tudo e por todos. 


\section{RESUMO}

SOUZA, J. L. de. Sobre a forma e o conteúdo da educação para o trânsito no ensino fundamental . 2010. $124 \mathrm{f}$. Tese (Doutorado) - Escola de Engenharia de São Carlos, Universidade de São Paulo, São Carlos, 2010.

Três pontos são consensuais entre os profissionais que trabalham com o tema trânsito no Brasil. Primeiro, a Educação para o trânsito é absolutamente imprescindível para reduzir a grande acidentalidade no trânsito do país e transformar o espaço público de deslocamento em um espaço de melhor convívio social. Segundo, a Educação para o trânsito não tem sido tratada com a importância que deve ter. Terceiro, é necessário aperfeiçoar os conteúdos programáticos relativos à Educação para o Trânsito no Ensino Fundamental. Neste trabalho é defendida a transversalidade como processo pedagógico na Educação para o Trânsito no Ensino Fundamental e proposto um ajuste complementar de conteúdo programático a ser adotado nas várias disciplinas em todos os períodos do Ensino Fundamental, com a incorporação de elementos da Engenharia seguindo a visão dos alunos detectada no projeto Rumo à Escola. A metodologia geral do trabalho encontra-se fundamentada em pesquisa teórica e em atividade de pesquisa de campo. A tese é fundamentada, sobretudo, nas informações levantadas nas pesquisas de campo realizadas no projeto Rumo à Escola, desenvolvido pelo DENATRAN em parceria com a UNESCO, nos trabalhos efetuados pelo Prof. Reinier Rozestraten e nas diretrizes da Legislação Educacional e de Trânsito Brasileira.

Palavras-chave: Engenharia de Tráfego - educação. Ensino Fundamental. 


\section{SUMMARY}

SOUZA,J.L. de. About the form and contento of traffic education in elementary school. 2010. 124 f. Thesis (Doctoral) - São Carlos Engineering School, São Carlos, 2010.

Three points are consensual by professionals with the theme of traffic in Brazil. First, traffic education is absolutely essential in order to reduce the great number of traffic accidents in the country and transform public roadways into socially friendly spaces. Second, traffic education has not been treated with the importance it should have been treated. Third, it is necessary to perfect the programmatic content related to traffic education in elementary teaching. This paper defends the transversality as a pedagogic process for traffic education in elementary teaching and proposes a complementary adjustment to programmatic content to be adapted by the various disciplines in all periods of elementary teaching, with the incorporation of elements of Engineering following the vision of the students detected in the "Off to School" (Rumo à Escola) project. The general working methodology is based on theoretical research and in field research activith. The thesis is based, above all, on information gathered in field research done in the "Off to School" project, developed by the DENATRAN (National Department of Transit) in partnership with UNESCO, on the work of Prof. Reinier Rozestraten, and on the guide lines of Brazilian Educational and Transit Legislation.

Keywords: Traffic Engineering - education. Elementary School 


\section{LISTA DE FIGURAS}

Figura 1 Estrutura organizacional do Projeto Rumo à Escola ------------------ 52

Figura 2 Capa e slogan do Projeto -------------------------------------------------- 53

Figura 3 Mapa com a localização dos Estados participantes do Projeto ------ 53

\section{LISTA DE TABELAS}

Tabela 1 Representação, por Estado, dos índices obtidos nas variáveis indicadas pelo Projeto Rumo à Escola 50

Tabela 2 Composição, por Estado, de índices agregados obtidos nas variáveis indicadas pelo Projeto Rumo à Escola. 51

Tabela 3 Distribuição, por Estado selecionado, da amostra representativa da pesquisa junto aos alunos 56

\section{LISTA DE GRÁFICOS}

Gráfico 1 Distribuição da amostra por tipo de escolas da amostra..... 57

Gráfico 2 Distribuição da amostra por idade dos alunos 57

Gráfico 3 Distribuição da amostra por série dos alunos ---------------------------- 57

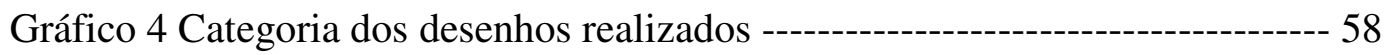

Gráfico 5 Categoria dos desenhos por tipo de escola ------------------------------- 59

Gráfico 6 Agrupamento das categorias por Estado ---------------------------------- 59

\section{LISTA DE SIGLAS}

CTB Código de Trânsito Brasileiro

DENATRAN Departamento Nacional de Trânsito

LDBEN Lei de Diretrizes e Bases da Educação Nacional

PCN Parâmetros Curriculares Nacionais

UNESCO Organização das Nações Unidas para a Educação, a Ciência e a Cultura.

UNICEF Fundo das Nações Unidas para a Infância

PNUD Programa das Nações Unidas para o Desenvolvimento 
1. INTRODUÇÃO.

1.1. Contextualização

1.2. Objetivos

1.3. Metodologia

1.4. Organização do trabalho

2. O TRÂNSITO 5

2.1. Princípios e conceitos relacionados ao trânsito

2.2. Direito e legislação de trânsito

2.3. Engenharia de trânsito

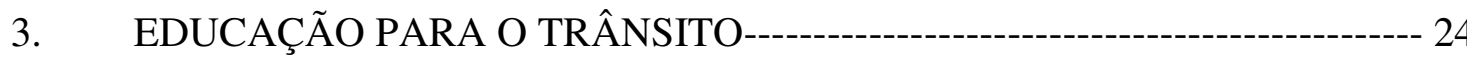

3.1. Fundamentos sobre educação e processo de aprendizagem

3.2. Aspectos Sociológicos: ser humano - sociedade - veículo e infraestrutura

3.3. Educação para o trânsito

3.4. Outras áreas de interferência

4. O PROJETO RUMO À ESCOLA 48

4.1. A parceria Denatran / Unesco para a educação de trânsito

4.2. Pesquisa sobre a visão de trânsito por parte dos alunos

4.3. A presença de elementos de Engenharia na percepção dos alunos

5. A TRANSVERSALIDADE NA EDUCAÇÃO PARA O TRÂNSITO 62

5.1. Conceito de temas transversais

5.2. Realidades do ensino fundamental no Brasil

5.3. O porquê do ensino de trânsito como tema transversal e não disciplina

5.4. Posicionamento de professores sobre a transversalização do tema trânsito

5.5. Posturas sinalizadas por instituições públicas e privadas no Brasil

5.6. Considerações finais

6. O CONTEÚDO PROGRAMÁTICO NA EDUCAÇÃO PARA O TRÂNSITO 75

6.1. A proposta psicopedagógica de Rozestraten

6.2. As Diretrizes Nacionais do Denatran

6.3. Proposta complementar

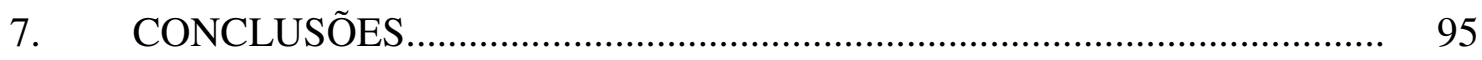

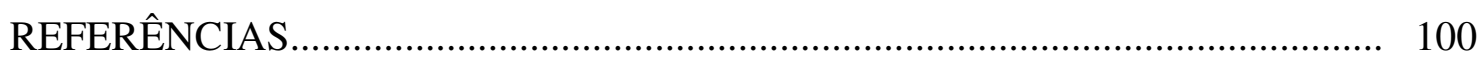

ANEXO - Ações e projetos de educação para o trânsito implementados por instituições públicas federais no Brasil. 


\section{1 \\ INTRODUÇÃO}

\subsection{Contextualização}

Desde a metade do século passado, quando o Brasil ainda caminhava rumo à utilização mais intensa de novas tecnologias, o país vive o drama de não se ter estabelecido políticas claras de informação e formação das pessoas sobre o uso adequado da máquina (automóvel) e dos sistemas por onde estas circulam. Assim, o tempo passou e o espaço público, que deveria ser de convivência entre os "homens", foi se tornando um espaço de disputa, em determinados momentos de batalha desigual entre indivíduos e máquinas.

Neste ano de 2010, o país chega à marca de quase 58.000.000 (cinquenta e oito milhões) de veículos, dados oficiais do Departamento Nacional de Trânsito (Denatran). Vive-se a era da modernidade mecânica e eletrônica, com o uso massivo do automóvel. O tempo passado parece não ter sido suficiente para que se pudesse aprender a conviver com os novos tempos, adquirir informação, adequar atitudes e gerar comportamento compatível com o pleno exercício da cidadania no sistema de trânsito.

As consequências para a sociedade brasileira apresentaram-se significativamente negativas. Considerando-se as estatísticas oficiais do Denatran, cerca de um milhão de acidentes de trânsito, de 30 mil mortes e de 300 mil feridos ocorrem por ano no Brasil, além de altos desperdícios de energia, tempo, danos ao meio ambiente, etc. 
Estudos do Instituto de Pesquisas Econômicas Aplicadas (IPEA, 2006) sinalizam que o país gasta, em valores atualizados, em torno de 32 bilhões de reais anualmente com os acidentes de trânsito (aproximadamente 1,3\% do PIB).

Com a publicação da Lei Federal N. 9.503/97, que instituiu o Código de Trânsito Brasileiro (CTB), o país ganhou um novo alento no sentido de buscar caminhos para se implementar projetos e ações educativas de trânsito, principalmente envolvendo a rede nacional de ensino.

Dentre as iniciativas governamentais, pode-se destacar o Projeto "Rumo à Escola", fruto de parceria entre o Departamento Nacional de Trânsito (Denatran) e a Organização das Nações Unidas para a Educação, a Ciência e a Cultura (Unesco), que efetivou pesquisa e implementou programa de educação para o trânsito na rede de ensino fundamental do Brasil, atuando em 15 capitais brasileiras, abrangendo uma amostra de 15 escolas em cada capital, sendo cinco da rede municipal, cinco estadual e cinco particular. Ao todo, o Projeto atingiu por volta de 300.000 alunos e 19.000 professores. O Projeto foi interrompido ao final do ano de 2003, tendo durado três anos.

Três pontos são consensuais entre todos aqueles que trabalham com o tema trânsito no Brasil. Primeiro, a Educação para o trânsito é absolutamente imprescindível para reduzir a grande acidentalidade no trânsito do país e transformar o espaço público de deslocamento em um espaço de melhor convívio social. Segundo, a Educação para o trânsito não tem sido tratada com a importância que deve ter. Terceiro, é necessário aperfeiçoar os conteúdos programáticos relativos à Educação para o Trânsito no Ensino Fundamental.

A importância da temática Educação para o Trânsito é destacada pela Lei Federal N. 9.503/97, que institui o Código de Trânsito Brasileiro (CTB), cujo artigo 76 estabelece a educação para o trânsito desde a pré-escola até o nível superior. Neste sentido, descreve a Lei, o Ministério da Educação, mediante proposta do Conselho Nacional de Trânsito (Contran) e do Conselho de Reitores das Universidades Brasileiras (CRUB), tem a missão de promover a adoção, em todos os níveis de ensino, de um currículo interdisciplinar com conteúdos programáticos sobre segurança de trânsito. 
Os artigos 78 e 320 do CTB garantem formas de arrecadação de recursos financeiros para uso, dentre outras ações, em educação de trânsito (BRASIL/CONGRESSO NACIONAL, 1997).

\subsection{Objetivos}

Os objetivos precípuos do trabalho são:

- Defender com argumentação sólida a transversalidade como processo pedagógico na Educação para o Trânsito no Ensino Fundamental;

- Propor um "novo" conteúdo programático - complementar - a ser adotado nas várias disciplinas em todos os períodos do Ensino Fundamental, com a incorporação de elementos da Engenharia seguindo a visão dos alunos detectada no Projeto Rumo à Escola.

Também é objetivo do trabalho, reunir e discutir informações relevantes sobre o tema Educação para o Trânsito, considerando o conceito ampliado de trânsito, os aspectos da legalidade, os fundamentos e princípios do processo de ensino e aprendizagem.

\subsection{Metodologia}

A metodologia geral do trabalho encontra-se fundamentada em pesquisa teórica e em atividade de pesquisa de campo.

A tese é fundamentada, sobretudo, nas informações levantadas nas pesquisas de campo realizadas no Projeto Rumo à Escola, desenvolvido pelo DENATRAN em parceria com a UNESCO, nos trabalhos efetuados pelo Prof. Reinier Rozestraten e nas diretrizes da Legislação Brasileira de Trânsito e da Educação.

Tendo como princípio o fato de que o processo investigatório parte de um problema já observado, utilizou-se do trabalho de pesquisa de campo junto a escolas do Ensino Fundamental de quinze capitais brasileiras, com a finalidade de complementar as informações teóricas discutidas. As pesquisas aplicadas foram: 
- Pesquisa junto a alunos do Ensino Fundamental $\left(1^{\circ}\right.$ ao $9^{\circ}$ ano $)$ sobre a sua visão de trânsito;

- Pesquisa junto a professores das escolas do Ensino Fundamental, visando conhecer a realidade do ensino e seu preparo para trabalhar com a temática trânsito na transversalidade;

- Pesquisa junto aos organismos públicos federais e instituições privadas que desenvolvem ações diretas de educação de trânsito.

\subsection{Organização do trabalho}

Neste capítulo1, encontram-se os seguintes tópicos: contextualização, objetivos, metodologia e organização do trabalho.

O segundo capítulo contém os fundamentos que envolvem o Trânsito no contexto deste trabalho.

No capítulo 3, são colocados os principais aspectos relativos à Educação, de forma geral, e à Educação para o Trânsito, em particular.

O quarto capítulo reúne as principais informações sobre o Projeto Rumo à Escola, desenvolvido em parceria pela UNESCO e o Denatran.

No capítulo 5, é discutida a transversalidade na educação de trânsito no Ensino Fundamental, com argumentação em defesa do processo de ensino transversal.

O sexto capítulo enfoca o conteúdo programático a ser empregado no Ensino Fundamental.

Finalmente, no capítulo 7, são alinhavadas as principais conclusões do trabalho. 


\section{2}

\section{O TRÂNSITO}

\subsection{Princípios e conceitos relacionados com o trânsito}

Segundo Rodrigues (2000), o direito de ir, vir e estar, de ocupar o espaço público, de conviver socialmente nesse espaço, são princípios fundamentais para compreender a dimensão do significado expresso na palavra trânsito, considerando-o como um processo histórico-social que envolve, principalmente, as relações estabelecidas entre homem e espaço, assim como as relações dos homens entre si. Dessa forma, pensar o trânsito como um fenômeno dos tempos modernos ou, ainda, associa-lo unicamente a problemas da atualidade - congestionamentos, acidentes, estresse - é um ledo engano. Este enfoque reducionista poderia ignorar e esvaziar toda a história de pessoas que desafiaram o desconhecido, venceram distâncias, trilharam caminhos, conquistaram espaços: transitando sempre, incansavelmente.

Como afirma Rodrigues (2000), a constatação dos fatos históricos nos leva a perceber que o processo de urbanização no Brasil ocorre, basicamente, a partir de 1930, sendo que na década de 50, com o incremento da industrialização, o país altera suas características de rural para urbano. Comparativamente, naquela época, cerca de $36 \%$ das pessoas viviam no meio urbano, hoje este índice é superior a 80\%. Foram necessários quase 322 anos para que o Brasil atingisse a cifra dos 10 milhões de habitantes, isto considerando os dados do primeiro censo demográfico oficial realizado em 1872, que registrou 9.930.478 habitantes. As cidades foram crescendo, gerando problemas sociais, econômicos, culturais e, especialmente, de locomoção. Atualmente, milhões de veículos circulam por todas as partes, seja durante o dia ou à noite. Mas, não foi sempre assim. Os animais foram, ao longo de décadas, o principal meio de locomoção para se vencer médias e longas distâncias nos lugarejos. 
Nas últimas quatro décadas, trânsito tem sido a palavra que descreve a circulação e o tráfego pelas vias. Na prática, é vocábulo reservado para descrever a utilização de vias por pessoas, veículos e animais, isolados ou em grupos, conduzidos ou não, para circulação, parada, estacionamento e carga ou descarga, conforme descreve o Código de Trânsito Brasileiro (CTB). O termo tráfego é usualmente empregado para designar o movimento de bens, pessoas ou animais pelos meios de transporte, referindo-se à operação, sinalização e fiscalização de vias públicas. O termo trânsito envolve ainda os aspectos legais e de comportamento humano.

O Código de Trânsito Brasileiro, instituído pela Lei federal N. 9.503/97, no artigo $2^{\circ}$, define que "as vias terrestres urbanas e rurais são as ruas, as avenidas, os logradouros, os caminhos, as passagens, as estradas e as rodovias, que terão seu uso regulamentado pelo órgão ou entidade com circunscrição sobre elas, de acordo com as peculiaridades locais e as circunstâncias especiais. As praias abertas à circulação pública e as vias internas pertencentes aos condomínios constituídos por unidades autônomas serão igualmente consideradas vias terrestres" (BRASIL/CONGRESSO NACIONAL, 1997).

Para Vasconcellos (1998, pg.11), "o trânsito é o conjunto de todos os deslocamentos diários, feitos pelas calçadas e vias da cidade, e que aparece na rua sob a forma da movimentação geral de pedestres e veículos. Assim sendo, o trânsito não é apenas um problema "técnico", mas, sobretudo uma questão social e política diretamente ligada às características da nossa sociedade".

Manhein (1979) já dizia que o sistema de trânsito funciona como uma espécie de bem coletivo que consome recursos para oferecer serviços e produz possíveis impactos (positivos ou negativos) no ambiente.

Em relação a terminologia adotada para, a Associação Brasileira de Normas Técnicas ABNT (1994) não distingue os conceitos entre trânsito e tráfego. Entretanto, na linguagem prática usada pelos técnicos, o acidente de tráfego é aquele que ocorre nas vias públicas e que gera prejuízos apenas para a operação do tráfego, ou seja, alteração 
no movimento de veículos, podendo provocar danos materiais. Nesta caracterização de acidente não deve ocorrer vítima humana.

Por sua vez, o acidente de trânsito é um somatório de falhas que um ou mais dos elementos que integram o sistema - via, veículo, homem - não foram capazes de superar (BRASIL/DEPARTAMENTO NACIONAL DE TRÂNSITO, 2002).

A Associação Brasileira de Medicina de Tráfego (1997) situa o acidente de trânsito como um problema de saúde pública.

Beux (1986, pgs. 19-20) destaca que "o acidente de trânsito pode ser também definido como um fator técnico-humano, que tem como protagonistas o elemento humano, o veículo, a via pública e o ambiente, o qual é antecedido e provocado ou relacionado, sobretudo, a conotações humanas - físicas, psicológicas, orgânicas, psíquicas, psicofisiológicas, mentais, sócio-econômicas ou morais. Trata-se de um evento onde, via de regra, há interação do condutor (com os componentes e fatores da sua personalidade), do veículo, da via e do ambiente".

Conforme Rozestraten (1988, pg.73), “o acidente pode ser visto como um ponto de partida para o estudo da psicologia do trânsito, uma vez que o comportamento humano é o principal responsável pelos mesmos, convém estudar as causas de seu mau funcionamento e quais os processos que podem levar a uma disfunção do sistema homem - veículo - via”. Ainda, são diversas as definições de acidente, e elas podem mudar em função de sua finalidade. Se quisermos uma definição mais abstrata, aplicável a tudo o que eventualmente é chamado de acidente, podemos dizer que: "É a interrupção abrupta de uma atividade por um evento inesperado".

Shinar (1978, pg. 101) propõe como definição para acidente: "Uma desavença não intencionada no trânsito, que implica algum dano e é noticiada à polícia". Esta desavença é qualquer acontecimento inesperado que interrompe a atividade normal.

Com base na proposição de Shinar (1978), Rozestraten (1988, pg. 74) sugere que o acidente seja "uma desavença não intencionada, envolvendo um ou mais participantes do trânsito, implicando algum dano e noticiada à polícia diretamente ou através dos 
serviços de Medicina Legal, podendo ainda, para outra finalidade, a exemplo da comparação entre motoristas acidentados e não acidentados, acrescentar: e pela qual o motorista foi julgado culpado pelas instâncias competentes".

Enfim, não há dúvidas de que é preciso pensar e repensar o trânsito, seu verdadeiro significado, suas prioridades, para termos uma forma sustentável de se viver e conviver no espaço público urbano ou rural. Nesta linha de pensamento, afirmam Ferraz, Júnior \& Bezerra (2008), a permanecer o modelo atual para o sistema trânsito, o "cenário vai se tornar ainda mais trágico caso políticas adequadas não forem colocadas em prática, pois a previsão é que os números negativos no mundo cresçam ainda mais, podendo atingir a marca de dois milhões de óbitos no ano de 2020”.

\subsection{Direito e legislação de trânsito}

A legislação referente ao trânsito no Brasil inicia-se esparsamente a partir de 1910, com o Decreto 8.324, de 27 de outubro, que aprovou o Regulamento para o serviço subvencionado de transporte por automóveis.

Neste decreto, os condutores eram ainda chamados de motoneiros, exigindo o art. 21 que se mantivessem constantemente senhores da velocidade do veículo, devendo diminuir a marcha ou mesmo parar o movimento todas as vezes que o automóvel pudesse ser causa de acidente.

O Decreto Legislativo $\mathrm{n}^{\mathrm{o}}$ 4.460, de 11 de janeiro de 1922, apesar de referir-se às estradas de rodagem, proibiu a circulação dos chamados carros de boi e cuidou da carga máxima dos veículos, além de, pela primeira vez, ter usado a expressão "mata-burros":

art. $1^{o} .(\ldots)$

art. $2^{\circ}$. (...)

$\S 1^{o}(\ldots)$

$\S 2^{o}$. As estradas deverão ser franqueadas a quaesquer vehiculos, automoveis ou não, com excepção dos chamados carros de boi de eixo móvel, que por elas não poderão transitar....

Art.. $5^{\circ}$. O poder executivo determinara a carga máxima dos vehiculos, tendo em consideração os typos usuaes de automóveis... 
Art.. $6^{o}$. No leito das estradas não poderão ser estabelecidas porteiras, tranqueiras ou qualquer fecho de igual natureza e fim; nos lugares em que isso for necessário, construir-se-ão mata-burros, que impeçam a passagem de animais e não embaracem o tráfego de automóveis.

O trânsito passou a gerar tão grandes problemas e implicações que, já em 1926, diversos países reuniram-se em Paris para examinar as modificações a serem introduzidas na Convenção sobre trânsito viário de 1909, tendo sido aprovada uma nova Convenção, disciplinando a circulação internacional de automóveis e a sinalização de trânsito.

Em 1927, o Decreto Legislativo no 5.141, de 05 de janeiro, "criou o Fundo especial para construção e conservação de estradas de rodagem federais, constituído por um adicional aos impostos de importação para consumo a que estão sujeitos gasolina, automóveis, autoônibus, autocaminhões, chassis para automóveis, pneumáticos, câmaras de ar, rodas maciças, motocicletas, bicicletas, side-car e acessórios para automóveis, estabelecendo, por exemplo, um imposto de 60 reis por quilograma de gasolina e mencionando pela primeira vez os autocaminhões e autoônibus".

Naquela época, os serviços de trânsito, o registro de veículo, a habilitação de condutores, a sinalização das vias, a fiscalização de infrações e a imposição de penalidades aos infratores eram da alçada e competência municipal.

Com o passar do tempo, os municípios foram perdendo a autonomia, principalmente na captação de receitas fiscais, e essas repartições foram, paulatinamente, entrando na insolvência financeira ou no descuido dos administradores, e em muitas cidades, nem mesmo foram criadas.

O Decreto $\mathrm{n}^{\circ} 18.323$, de 24 de julho de 1928, aprovou o Regulamento para a circulação internacional de automóveis no território brasileiro e para a sinalização, segurança do trânsito e polícia nas estradas de rodagem, citando no seu artigo 25 que a competência para a fiscalização era da União, Estados ou municípios, conforme tivesse o domínio da estrada:

“Art. 25. A fiscalização das estradas de rodagem, para execução das medidas de segurança, comodidade, e facilidade de trânsito, será feito 
pelas autoridades federais, estaduais ou municipais, conforme a estrada esteja sob o domínio da União, dos Estados ou dos municípios."

Tratando dos impostos e das placas de identificação dos veículos, estabeleceu que nenhum veículo poderia trafegar nas estradas de rodagem sem o prévio pagamento da licença respectiva na municipalidade de origem (art. 58) e curiosamente, ao tratar das multas e sua aplicação, permitiu a qualquer pessoa de notória idoneidade autenticar as infrações ocorrentes e levá-las ao conhecimento de quem de direito (art. 86), cabendo à mesma ainda metade do valor da multa arrecadada (art. 86, parágrafo único). Pensavase que, com isto, haveria motivação para denunciar-se os infratores e acabar com a impunidade.

A Convenção Internacional de Paris, de 1926, é ratificada pelo Governo brasileiro, através do Decreto ${ }^{\circ} 19.039$, de 17 de dezembro de 1929.

O primeiro Código Nacional de Trânsito surgiu em 28 de janeiro de 1941, por meio do Decreto-Lei $n^{\circ}$ 2.994. Todavia, teve curta duração, pois oito meses depois foi revogado pelo Decreto-Lei 3.651, de 25 de setembro de 1941, que deferia expressamente aos Estados a atribuição de regulamentar o trânsito de veículos automotores, devendo, contudo, a legislação adaptar-se à Lei Nacional. No capítulo VII, referindo-se aos impostos e taxas, obrigou o registro na repartição de trânsito com jurisdição no município.

O resultado do II Congresso Nacional de Trânsito, realizado em 1958, foi produzido e entregue ao Ministro da Justiça da época, tendo-se o primeiro anteprojeto do novo Código de Trânsito, para substituir o que vigorava desde 1941.

Em 26 de agosto de 1960, foi remetido ao Congresso Nacional e aprovado, finalmente, a 21 de setembro de 1966, pela Lei no 5.108, surgindo o Código Nacional de Trânsito, composto de 131 artigos, estabelecendo, em seu art. $2^{\circ}$, que os Estados poderiam adotar normas pertinentes às peculiaridades locais, complementares ou supletivas da legislação federal, e no art. $3^{\circ}$, a composição da administração do trânsito. 
“Art. $3^{\circ}$ Compõem a administração do trânsito como integrantes do sistema nacional de trânsito":

a) o Conselho Nacional de Trânsito, órgão normativo e coordenador;

b) os Conselhos Estaduais de Trânsito, órgãos normativos;

c) os Conselhos Territoriais de Trânsito, órgãos normativos;

d) os Conselhos Municipais de Trânsito, órgãos normativos (grifo nosso);

e) os Departamentos de Trânsito e as Circunscrições Regionais de Trânsito, nos Estados, territórios e Distrito federal, órgãos executivos;

f) os órgãos rodoviários federal, estaduais e municipais, também órgãos executivos

Destaca no parágrafo único que os Conselhos Territoriais e Municipais seriam de criação facultativa e ainda que os Conselhos Municipais seriam permitidos apenas nos municípios com população superior a duzentos mil habitantes (art. $7^{\circ}, \S^{\circ}$ ), tendo as mesmas atribuições dos Conselhos Estaduais de Trânsito, CETRAN's ( art. $7^{\circ}, \S^{\circ}$ ).

Tratando do registro e licenciamento, o código determinou a obrigatoriedade do registro a todos os veículos automotores (art. 52) e do licenciamento aos veículos automotores, de propulsão humana, tração animal, reboques, carretas e similares (art. 57), devendo o registro ser realizado pelas repartições de trânsito (art. $52, \S 1^{\circ}$ ) e o licenciamento no município de domicílio ou residência (art. 57). Ainda neste código foi criado o Registro Nacional de Veículos Automotores, RENAVAN, (art. 55).

Antes mesmo da sua regulamentação, o Código Nacional de Trânsito sofreu profundas alterações através do Decreto-Lei no 237 , de 23 de fevereiro de 1967, enfatizando:

- a extinção dos Conselhos Municipais de Trânsito;

- a criação do Departamento Nacional de Trânsito;

- delegou ao CONTRAN a competência para estabelecer os equipamentos obrigatórios dos veículos;

- criou a Junta Administrativa de Recursos de Infração, JARI.

Em 16 de janeiro de 1968, foi aprovado pelo Decreto $\mathrm{n}^{\circ} 62.127$ o Regulamento do Código Nacional de Trânsito, RCNT, composto de 264 (duzentos e sessenta e quatro) artigos e 8 (oito) anexos. O Regulamento, em muitos aspectos, parece ter extrapolado a 
sua função regulamentadora, quando, por exemplo, estendeu as atribuições do CONTRAN estabelecidas em 14 (quatorze) incisos do código (art. 5) em nada menos que 43 (quarenta e três), chegando por algumas vezes até a alterar o próprio texto previsto no Código, sendo tal fato objeto de inúmeras críticas.

O regulamento que trata da distribuição de competências registrou, nos arts. 35 a 37, as competências da União, dos Estados e dos municípios, estabelecendo como competências dos Departamentos de Trânsito, Detrans, entre outras: cumprir e fazer cumprir a legislação de trânsito, aplicando as penalidades previstas neste regulamento; vistoriar, registrar e emplacar veículos; expedir o Certificado de Registro de Veículo Automotor; arrecadar as multas aplicadas aos condutores e proprietários de veículos, por infrações ocorridas na área de sua jurisdição. E as Circunscrições Regionais de Trânsito, Ciretrans, especialmente: cumprir e fazer cumprir a legislação de trânsito; expedir documentos de habilitação para dirigir; implantar sinalização; expedir Certificado de Registro; e fazer estatística de trânsito.

O Decreto n ${ }^{\circ}$ 62.926, de 28 de junho de 1968, deu nova redação aos arts. 36 e 37 do RCNT, definindo a competência do município para implantar sinalização e licenciar veículos:

“Art. 37 Compete aos Municípios, especialmente":

I - regulamentar o uso das vias sob sua jurisdição, considerando o disposto no art. 46;

II - conceder, autorizar ou permitir exploração de serviço de transporte coletivo para as linhas municipais;

III - regulamentar o serviço de automóvel de aluguel (táxi);

IV - determinar o uso de taxímetro nos automóveis de aluguel;

V - limitar o número de automóveis de aluguel (táxi);

VI - licenciar veículos;

VII - implantar sinalização nas vias sob sua jurisdição.

A competência dos municípios para licenciar veículos perdurou até a publicação do

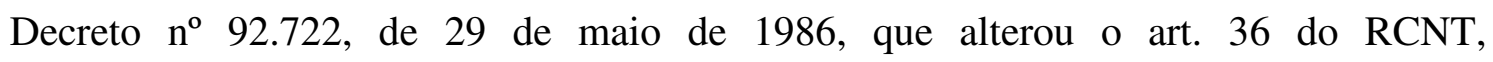
determinando a competência aos Estados, ao Distrito Federal e aos Territórios para registrar, vistoriar, emplacar e licenciar veículos, revogando ainda o inciso VI do art. 37 
do referido regulamento, que havia dado competência aos municípios para licenciarem veículos.

Nesse momento, já não se discutia mais o direito do município regular o trânsito em seu território, não podendo, porém, fugir às normas federais ou supletivas estaduais, tanto mais que, segundo o art. 22, inciso XI, da Constituição Federal de 1988, diz: "Compete à União legislar sobre Trânsito e Transporte”.

Assim se manifestou o ilustre Desembargador Almeida Bicudo (RJTJSP, 16:227):

"Vê-se, assim, que, ao distribuir a competência entre os Estados e os Municípios, o RCNT afasta qualquer dúvida. A competência do Estado recai sobre as 'estradas e respectivas faixas de domínio'; a do Município sobre 'as vias sob sua jurisdição'. Podem, pois, Estado e Município, cada um sobre as suas respectivas vias de comunicação, atendendo ao disposto no art. 46 do Regulamento: instituir sentido único de trânsito; proibi-los para veículos ou animais; estabelecer limites de velocidade, de peso e dimensões; firmar áreas de estacionamento; proibir conversão ou retorno; impor restrições ao uso das vias, mediante fixação de local, horário e período para estacionamento, embarque e desembarque de passageiros ou cargas. O que não pode é o Município disciplinar o trânsito nas estradas estaduais ou o Estado regulamentar o uso das ruas da cidade" (citado por PINHEIRO, 1987, p.10).

O parágrafo único do art. 37 deixou claro que "os municípios, mediante convênio, poderão deferir aos respectivos Estados ou Territórios a execução total ou parcial de suas atribuições relativas ao trânsito". Assim, de acordo com a capacidade dos municípios de gerenciarem o trânsito nas vias sob sua jurisdição, foram criadas diversas entidades municipais de trânsito, como a Companhia de Engenharia de Tráfego do Município de São Paulo e a Superintendência de Engenharia de Tráfego no Município de Salvador, entre outras.

No momento atual, o trânsito no Brasil é regulado pela Lei federal N. 9.503, de 23 de setembro de 1997, publicada em 24 de setembro e retificada em 25 de setembro de 1997, entrando em vigor no dia 22 de janeiro de 1998, já com as modificações introduzidas pela Lei 9.602/98. Esta Lei institui o Código de Trânsito Brasileiro e 
atribuiu competência ao CONTRAN - Conselho Nacional de Trânsito para regulamentá-la, no que couber.

Além das alterações apresentadas pela Lei federal N. 9.602/98, o CTB - Código de Trânsito Brasileiro sofreu outras alterações, a exemplo da Lei federal N. 11.334/06, que modificou a gradação das penalidades para a infração de excesso de velocidade, e a Lei federal N. 11.705/08 (conhecida como "Lei seca”), que deu nova redação aos artigos 165 e 277 do CTB, abordando a questão de dirigir sob influência de álcool ou outra substância psicoativa. Também já se discute no Congresso Nacional propostas de modificações mais amplas no atual Código. O fato é que a legislação de trânsito, que é parte do Direito Administrativo e também Penal, está em constante processo de ajustes.

\subsection{Engenharia e trânsito}

Para falar de engenharia, vale começar pela Construção Civil, cuja importância é reconhecida em todas as civilizações, assim como a extração mineira, tanto na representatividade civil quanto para fins militares. Durante muitos séculos, a ciência da construção permaneceu indissociada da arte e, no período do Renascimento, faz surgir uma nova categoria profissional, a dos engenheiros. Em sua primeira fase, eram considerados engenheiros os inventores, os que utilizavam os engenhos para fins de atividades correntes na indústria, na agricultura, outras áreas, e também para fins militares. Registra a história que as primeiras formações de caráter técnico científico destes profissionais advêm das escolas que ministravam o ensino da arte da guerra e que utilizavam as fortificações para a defesa e os engenhos como armas de ataque.

No contexto atual, a diferenciação das atividades do projetista e construtor, considerando as vertentes da arquitetura e da engenharia civil e militar, seguiu moldes similares aos adaptados por países como a França, que criou a "École des Ponts et Chaussées" - formando os quadros superiores das obras públicas - e a "École des Beaux Arts" - à qual se atribuiu a concessão dos diplomas de arquitetura. Antes, porém, em meados do século XVIII, as construções em grande escala eram realizadas por engenheiros militares. Ainda neste século, o termo engenharia civil ou de transportes começou a ser usado para referenciar-se a trabalhos de engenharia executados com fins não militares. 
Com a evolução da técnica, o desenvolvimento industrial, a entrada e generalização da eletricidade, a engenharia diferenciou-se em diversos ramos: mecânica, eletrotécnica, química, etc.

Descrita como canção da engenharia, assim abordam os autores:

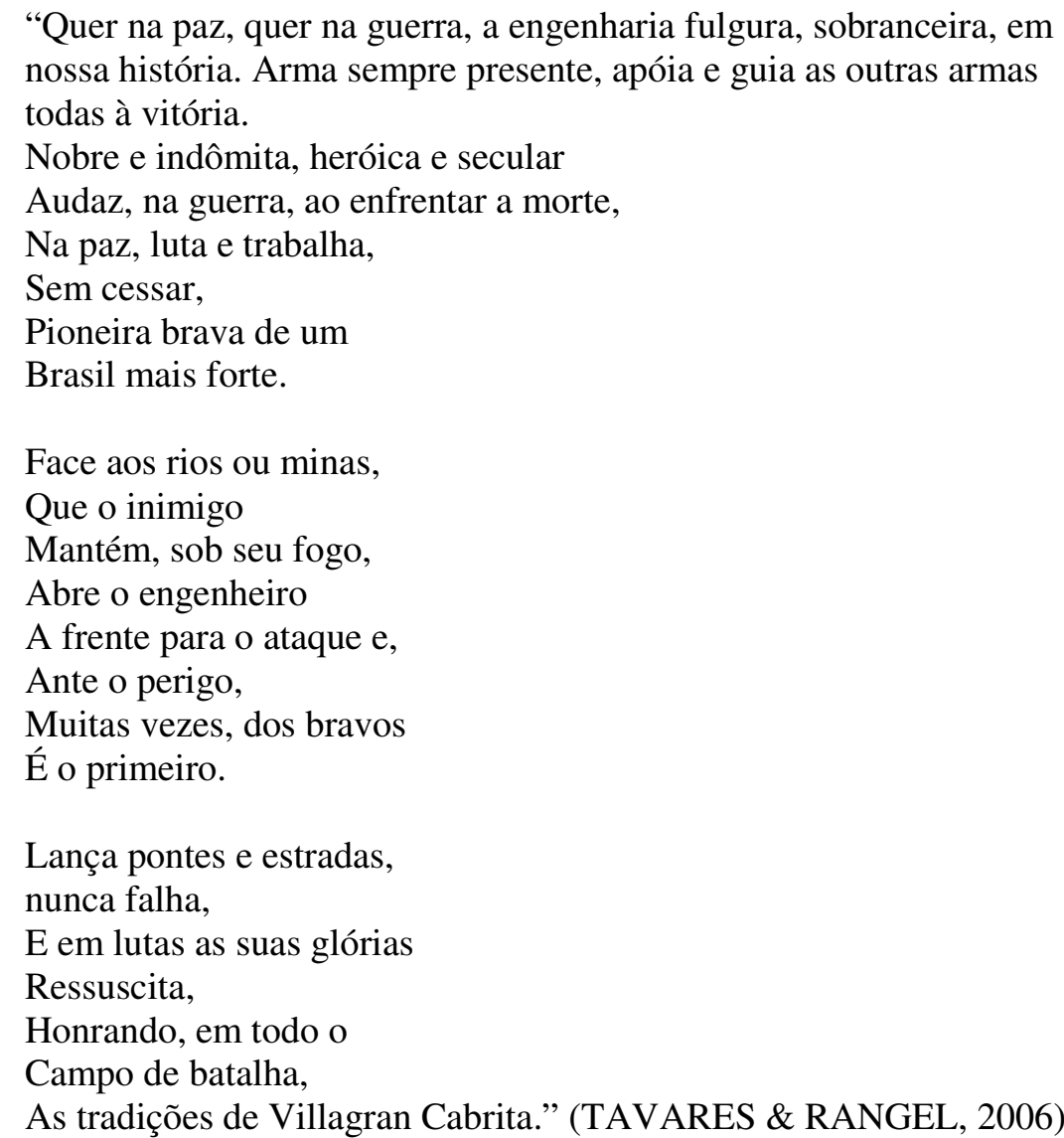

No Nordeste brasileiro, a participação dos Batalhões de Engenharia de Construção nos programas de obras públicas, por ocasião das secas cíclicas, trouxe importantes benefícios às populações flageladas.

No Brasil, ao longo do período colonial, se destacaram duas categorias de profissionais da engenharia: os oficiais engenheiros e os mestres pedreiros. Os mestres pedreiros eram conhecidos como mestres de risco e eram os responsáveis por projetar e construir as edificações em geral (casas, igrejas,...). Apesar de não ter muita base científica, seu conhecimento era transmitido de geração para geração. Por sua vez, os oficiais engenheiros eram oficiais do exército português e tinham por missão principal realizar 
obras de engenharia. Não obstante nem todos possuírem curso regular de engenharia, eram as únicas pessoas com conhecimento sistemático da arte de construir.

$\mathrm{Na}$ Europa, a arte de construir, com base científica, nasceu dentro dos exércitos. Com a invenção da pólvora e das armas de fogo, basicamente a partir do século XVII, o planejamento e execução das obras passaram a exigir profissionais habilitados. A necessidade de se construir estradas, pontes e portos para fins militares, além de obras que garantissem boa defesa contra os projéteis dos canhões, forçou o surgimento dos oficiais engenheiros e a criação de corpos especializados de engenharia nos exércitos.

No século XIX data a origem da Escola de Engenharia no Brasil, quando José Bonifácio de Andrada e Silva, à época residindo na Europa, incentivara John Theron Mackenzie a promover no Brasil o ensino dos modernos conhecimentos tecnológicos, nos moldes pedagógicos das Universidades americanas. John Theron destinou em seu testamento um significativo legado com a finalidade específica de se instalar no país uma Escola de Engenharia, cabendo à Igreja presbiteriana dos Estados Unidos a missão de efetivar este empreendimento. A construção do prédio onde se instauraria a primeira Escola de Engenharia brasileira terminou em fevereiro de 1896 e teve como fundador o médico e educador, Prof. Dr. Horace Manley, e como seu primeiro diretor, o engenheiro Dr. Willian Alfred Waddell.

A construção civil e a engenharia, inicialmente fundamental para as questões militares, se tornaram peças indispensáveis para o desenvolvimento das civilizações, para o desenvolvimento do país. Modernizando e gerando novas tecnologias com o passar dos tempos, ramificou-se em diferentes especialidades, dentre as quais destacam-se a engenharia civil, a engenharia de transportes, a engenharia mecânica e a engenharia de trânsito ou tráfego, áreas de particular interesse para o estudo do objeto desta tese.

A expansão dos conhecimentos científicos e a aplicação a problemas práticos fazem surgir a figura do engenheiro, resultado da evolução ocorrida ao longo de milhares de anos. Esta engenharia, fundamentalmente fruto da matemática e da explicação dos fenômenos físicos, delimita o marco divisório entre a engenharia do passado e a engenharia moderna. A característica básica da engenharia do passado foi o empirismo, pois trabalhava com base na prática transmitida, na própria experiência e no espírito 
criador. Por outro lado, "a engenharia moderna caracteriza-se pela aplicação generalizada dos conhecimentos científicos à solução de problemas" (BAZZO \& PEREIRA, 2002, p.183).

A história da engenharia moderna não foi marcada apenas de sucesso, muitos foram os fracassos no início da aplicação dos conhecimentos científicos. Dentre estes, citam-se o fracasso de Huyghens no desenvolvimento de um motor de explosão a pólvora; a incapacidade de três renomados matemáticos, nomeados pelo Papa, em 1742, para encontrarem as causas dos indicativos de colapsos no domo da basílica de São Pedro; ou, o próprio resultado obtido por Galileu, publicado em 1638, cuja distribuição de tensões estava equivocada. Assim cresceu a engenharia moderna, e somente em 1814 é que o termo "engenharia" foi descrito em dicionário em língua portuguesa.

Suplantando obstáculos, grandes obras da engenharia civil foram erguidas e traçadas no Brasil, tornando viável o deslocamento de pessoas, o transporte de mercadorias e o escoamento de nossas riquezas. Abrindo estradas, construindo pontes, ferrovias, portos, aeroportos, vias para o tráfego urbano, canalizando e transportando água, energia elétrica, gás, minério, óleo, e fazendo circular tantos outros de interesse da nação.

Das antigas construções datadas de séculos antes da era cristã às modernas obras da engenharia civil e da arquitetura, o fato é que não concebe a possibilidade de desenvolvimento de um povo sem o apoio da tecnologia advinda desta área profissional. Contudo, tais obras determinaram atitudes e comportamento ao longo da história, geraram hábitos e, quando analisadas no contexto da circulação urbana, afetam significativamente o cotidiano e a individualidade do ser humano, assunto este que será melhor detalhado na abordagem sobre a especialidade engenharia de trânsito.

Uma das especialidades da engenharia civil é a engenharia de transportes. Para melhor compreendê-la, requer recordar na história a forma de transporte utilizada nos séculos XV e XVI, quando os europeus, principalmente portugueses e espanhóis, lançaram-se nos oceanos Pacífico, Índico e Atlântico com objetivos de descobrirem uma nova rota marítima para as Índias e encontrar novas terras. Foi a era das grandes navegações e descobertas marítimas. 
No século $\mathrm{XV}$, as principais especiarias (pimenta, açafrão, gengibre, canela e outros temperos) eram monopólio dos comerciantes de Veneza ou Gênova, que, por sua vez, tinham acesso aos mercados orientais, tendo a Índia como o principal deles. O canal de comunicação e o transporte das mercadorias se faziam através do mar mediterrâneo, dominado pelos italianos. Encontrar, portanto, um novo caminho para as Índias era uma tarefa difícil, porém importante para os anseios de Portugal e Espanha.

Como principal forma de transporte da época surge o interesse e preocupação com os estudos náuticos, chegando os portugueses a criar a Escola de Sagres, centro específico de estudos nesta área. Juntamente com o avanço da construção naval, evidencia-se a necessidade e presença dos instrumentos de navegação, a exemplo da bússola, o astrolábio e a balestilha, sendo os dois últimos utilizados para localizar os astros como pontos de referência. Quanto ao meio de transporte, considerado resistente e rápido à época, predominam as caravelas, que, apesar de sofrerem naufrágios, cumpriam com os objetivos previstos. Eram capazes de transportar grandes quantidades de mercadorias e homens.

Das navegações e descobertas portuguesas, espanholas e outros, sempre figurou a construção do meio de transporte, nos tempos modernos associados aos conhecimentos e tecnologias da engenharia.

Segundo Marconi \& Presotto (1986), na antiguidade, o primeiro vestígio de transporte aparece no Mesolítico Escandinavo, com um tipo de canoa. No início, o homem utilizou-se de troncos, cabaças e peles cozidas e infladas para flutuar ou sustentar-se sobre as águas. Ressalta, entretanto, Marconi que o meio de locomoção mais antigo e rudimentar é o próprio caminhar.

A especialidade engenharia de transporte pode ser pensada como aquela parte da engenharia civil que discute o sistema de transporte a ser implementado (modais marítimo / fluvial, ferroviário, aéreo, terrestre); analisa a possibilidade de integração dos sistemas; e define a logística operacional dos mesmos.

O bom funcionamento da cidade, do Estado e do país passa por uma boa definição e organização de seu sistema de transporte. Neste sentido, o planejamento de transporte é 
a atividade que define a infraestrutura necessária para que se tenha a circulação de pessoas e mercadorias de forma adequada, organizando os sistemas de transporte, que ficam sujeitos à regulamentação pública (ANTP, 1997).

Fazer o transporte de bens, pessoas e mercadorias de forma segura, com agilidade, conforto e economia é, portanto, também uma atividade inerente à engenharia de construção civil. A constituição da infraestrutura viária deve ser articulada com a definição e planejamento de seu sistema de transporte - responsabilidade específica do ramo engenharia de transportes - e ainda pensada com vistas à operação e fiscalização do conjunto, sendo, neste caso, uma nova ramificação da engenharia conhecida como engenharia de tráfego ou trânsito, que será também abordada neste item.

Não obstante a importância e volume de interferências da engenharia civil, com suas especialidades, no processo de evolução da humanidade e na viabilização de soluções e tecnologias para atender as demandas e necessidades de deslocamentos, merece também destaque o papel de outra área da engenharia que contribuiu, de forma significativa, com a efetivação destes deslocamentos, gerando máquinas, motores, e tecnologias que permitiram transpor médias e longas distâncias em curtos espaços de tempo. Referenciase à engenharia mecânica e à engenharia automotiva, objetos de análise seguinte.

Considerada mola propulsora da revolução das máquinas que passariam a fazer o transporte de pessoas e mercadorias, a engenharia mecânica e a engenharia automotiva respondem pela constante evolução dos motores, da capacidade, do designer e também dos equipamentos de segurança apresentados pelos veículos automotores.

É função da engenharia mecânica o projeto de motores, máquinas, instalações, veículos e outros produtos das indústrias mecânicas. Dividida em três classes, a mecânica pesada - que trata de elementos como turbinas hidráulicas, guindastes, pontes rolantes etc -; a produção em série - geralmente ocorre em linhas automatizadas, como carros, geladeiras, etc. -; e a mecânica fina - instrumentos de grande nível de precisão, a exemplo de instrumentos de medição, eletroeletrônicos em geral -.

Vale ressaltar que a constante automação das linhas de produção e o uso efetivo dos computadores na engenharia propiciaram o surgimento de uma nova área, denominada 
mecatrônica ou de controle e automação. É a fusão da mecânica com a eletrônica. Automatização muito comum no processo de fabricação de veículos.

Embora tenha nascido ainda no século XIX, foi no século XX que a indústria automobilística viveu o auge de seu desenvolvimento. Nos primeiros anos do novo século, os carros ainda contavam com motores pouco potentes e começavam a nascer as linhas de produção.

Em meio à explosão tecnológica vivida após a II Guerra Mundial, a indústria automobilística viveu um período de grande brilho. Era a época da "juventude transviada", apaixonada pelos grandes esportivos e, principalmente, pelos " rabos-depeixe". É a engenharia impondo seu domínio sobre tecnologias e construindo meios de transporte capazes de se identificar com os desejos e sonhos de consumo do homem.

Enfim, nos últimos anos do século XX, o mundo viveu a maior revolução tecnológica de sua história. Nunca se teria avançado tanto e em tão pouco tempo. Assim, surgem automóveis dotados de grande potência, com ousadas soluções mecânicas e aerodinâmicas. Revestidos de boas tecnologias, são também estes automóveis motivo de grandes preocupações para o funcionamento do trânsito, considerando que as máquinas exigem sistema viário e adaptações da engenharia de tráfego que ainda não se encontram satisfatórias para que os mesmos possam aplicar ou colocar em prática o desempenho para os quais estão sendo projetados.

Igualmente, estas máquinas nem sempre são utilizadas com o mínimo de racionalidade por parte do condutor, que, muitas vezes, transforma sua tecnologia em poderio armamentista de morte. Bem vindos às máquinas de deslocamento terrestre pós-década de 70, frutos, dentre outros, do avanço técnico e tecnológico da engenharia mecânica e da engenharia automotiva.

Com o uso cada vez mais significativo da máquina, sobressai a importância e a necessidade de se observar a especialidade da engenharia denominada engenharia de trânsito ou tráfego. 
Embora não existente como área de formação de graduação no ensino superior brasileiro, a engenharia de trânsito retrata uma especialidade que deve atuar de forma integrada, em especial, à engenharia de construção civil. Assim, tem-se como passo primordial de engenharia para a organização adequada de um sistema de trânsito que o sistema viário seja bem planejado pela engenharia civil. Por sua vez, este planejamento do sistema viário sofrerá forte influência da destinação e do uso do solo aplicados pela cidade.

Talvez se possa imaginar a engenharia de trânsito como sendo uma grande cobertura sob a qual se encontra uma área de formação acadêmica e duas grandes especialidades. Sob este teto tem a engenharia de construção civil, responsável pelas construções e obras de arte do sistema viário, e cujo Código de Trânsito Brasileiro - CTB, em seu artigo 320, chamou de "engenharia de campo". Igualmente, encontra a especialidade denominada engenharia de transportes, responsável pela definição e organização do sistema de transportes (os diferentes modais), pela análise e integração deste sistema e por sua logística operacional. A segunda especialidade seria a engenharia de tráfego, responsável pela operação do trânsito após liberado para uso do público, pela sua sinalização e também fiscalização do sistema de trânsito. Enfim, este conjunto de ações, que vão da engenharia civil até a aplicação das tecnologias e técnicas na operação do tráfego, forma o que se denominou de engenharia de trânsito.

De acordo com a Associação Brasileira de Normas Técnicas - ABNT, não há diferença teórica na denominação dos termos "tráfego" e "trânsito". Assim, define a Engenharia de Tráfego ou de Trânsito como sendo:

"Parte da Engenharia que trata do planejamento do tráfego e do projeto e operação das vias públicas e áreas adjacentes, assim como do seu uso para fins de transporte, sob o ponto de vista de segurança, conveniência e economia." (FERRAZ, FORTES \& SIMÕES, 1999, p.7)

É objetivo da engenharia de trânsito fazer com que a circulação de veículos e pessoas seja realizada com o máximo de eficiência, segurança, comodidade, fluidez e acessibilidade. 
Com vistas no campo de atuação da engenharia de trânsito, pode-se então pensar na seguinte divisão terminológica em relação ao Sistema Viário e ao Sistema de Trânsito: o sistema viário irá dispor do conjunto de vias e obras de arte (viadutos, pontes, túneis, trevos, rotatórias,...) destinados ao fluxo de veículos ou pedestres. Por sua vez, o sistema de trânsito abrangerá, além do previsto no sistema viário, o conjunto das normas de circulação, estacionamento e operação de embarque e desembarque de passageiros, carga e produtos. Ou seja, no sistema de trânsito, o comportamento das pessoas se mistura às técnicas e tecnologias da engenharia.

Algumas das intervenções realizadas pela engenharia de trânsito no sistema viário:

De um modo geral, as intervenções no sistema viário advindas da engenharia passam por três grandes áreas: O Planejamento Urbano; O Planejamento do Transporte; e o Planejamento da Circulação.

Quando se refere ao planejamento urbano, está se falando sobre o uso adequado do solo, sua ocupação construtiva e os equipamentos públicos. Estes fatores são fundamentais em uma cidade para que a mesma possa apresentar um sistema viário, o fluxo de veículos e a circulação das pessoas em condições de qualidade. Com o objetivo de reforçar a importância do uso correto do solo, a legislação de trânsito brasileira impôs regra específica em seu artigo 93, que diz o seguinte:

"Nenhum projeto de edificação que possa transformar-se em pólo atrativo de trânsito poderá ser aprovado sem prévia anuência do órgão ou entidade com circunscrição sobre a via e sem que do projeto conste área para estacionamento e indicação das vias de acesso adequadas." (BRASIL. CONGRESSO NACIONAL, 1997)

Interligado ao planejamento urbano está o planejamento do transporte, que, em si, implica organizar o sistema viário, o sistema de transporte público e aplicar as tecnologias e técnicas disponíveis para o bom funcionamento da engenharia de tráfego. 
Com os itens anteriormente ajustados, quais sejam, uso do solo e sistema de transporte, necessário se faz definir o planejamento da circulação. Pensar a divisão do espaço e a sua regulamentação de uso e cuidar do processo educativo e de fiscalização.

Do conjunto das intervenções realizadas pela engenharia de tráfego em uma cidade, em geral, as mais visíveis e conhecidas são: a sinalização vertical e horizontal; a definição e uso de faixas exclusivas para ônibus; a constituição e construção de caneletas exclusivas para ônibus; a inversão temporária de sentido de circulação; a implementação de semáforos; o uso de rotatórias; e a fiscalização eletrônica.

As intervenções apresentadas pela engenharia de tráfego são muito importantes para se dar vazão à demanda crescente que se tem de necessidades de deslocamentos das pessoas. Contudo, tais intervenções, como outras, geram, com o passar do tempo, hábitos e são interferência direta no processo educativo de trânsito da população. As pessoas acostumam-se e organizam sua forma e meio de deslocamento em função do que a engenharia oferta para sua locomoção, mobilidade e acessibilidade dentro das cidades. Esta capacidade de criar regras de circulação faz com que a engenharia seja cada vez mais uma área do conhecimento com forte presença no processo de ensino e aprendizado das pessoas quando o tema se refere a trânsito, fato este verificado durante pesquisa de campo do Projeto Rumo à Escola, parceria da UNESCO com o Denatran. 


\section{3 \\ EDUCAÇÃO PARA O TRÂNSITO}

\subsection{Fundamentos sobre educação e processo de aprendizagem}

O homem apresenta grande parte do seu comportamento determinado pela sua capacidade de aprendizagem. Através desta, adquire uma série de conhecimentos que não trazia por hereditariedade. Este aprendizado pode ocorrer através de sua experiência individual, ou seja, uma descoberta independente, e também pode advir da transferência de conhecimentos de indivíduo para indivíduo.

Aprender por meio de outros se tornou a grande arma do homem na luta pela preservação da vida. Assim, ele se utiliza das experiências de seus contemporâneos e antepassados. Herdar estas experiências de outros indivíduos foi, sem dúvida, um valioso benefício, o qual seria impossível de ser desfrutado sem o desenvolvimento da linguagem. Através da mesma, a herança cultural humana se transmitiu pelos indivíduos e sociedades.

O exercício desta capacidade do homem para aprender experiências, possibilitando-lhe agir segundo atitudes e comportamento adquirido, deu origem ao processo denominado educação.

Educação, portanto, pode ser entendida como o processo pelo qual o homem, mediante sua capacidade para aprender, adquire experiências que atuam sobre a sua mente e o seu físico. Algumas destas experiências terão a capacidade de influenciar o seu comportamento em termos de ideias ou de ações, enquanto outras poderão ser rejeitadas ou não-assimiladas. Trata-se de uma seleção qualitativa das experiências aprendidas ${ }^{1}$.

A educação pode ainda se classificar como sistemática ou assistemática. Será considerada sistemática quando permitir ao educando realizar uma aquisição de experiências de forma ordenada, dentro de algum método de ensino previamente

\footnotetext{
${ }^{1}$ NISKIER, Arnaldo. Tecnologia Educacional: uma visão política, 1993.
} 
estabelecido. É ministrada predominantemente na escola, mas pode, também, ocorrer no lar, na igreja, e em outras instituições onde se educa com a intenção prévia de se educar.

A educação não sistemática ocorre quando as experiências são adquiridas de uma forma não ordenada ou sem um método previamente preparado para tal fim. Os meios de comunicação, como o rádio, a televisão, o cinema, o teatro, constituem um bom exemplo de veículos que ministram este tipo de educação. $\mathrm{O}$ fator fundamental é que as instituições ministram a educação sem a intenção principal de educar.

A história tem nos mostrado que as finalidades da educação têm sido diversas e às vezes antagônicas ao longo dos anos. Para que aprendo? O que devo aprender? Estas são perguntas colocadas pelo homem desde a Antiguidade, mas a resposta tem variado muito conforme a época e o pensamento dos diversos educadores.

A educação nas cidades de Atenas e Esparta, da antiga Grécia, por exemplo, era ministrada visando atingir objetivos diferentes. Em Atenas, o objetivo estava voltado para o aprimoramento da razão, o cultivo das artes, ciências e filosofia. Em Esparta, o alvo era o bom preparo físico para o exercício da vida militar.

Em Roma, o ideal educacional se dirigia para a integração do indivíduo à vida social. Valorizavam-se as virtudes do cidadão, caindo em certo desprezo as manifestações da individualidade.

Na Idade Média, a preocupação primordial estava dominada pelo aspecto religioso do ensino. As coisas do espírito monopolizavam as atenções em detrimento da educação física.

$\mathrm{Na}$ Renascença, a educação começou a trilhar caminho oposto aos objetivos medievais. Agora se pretendia uma valorização do homem, cujo interesse deveria estar voltado para as coisas da terra e não do céu. O desenvolvimento das ciências começa a substituir a estrutura teológica que sustentava a Idade Média. Esta preocupação científica ainda se faz presente nos tempos modernos, mas também já está sendo superada por concepções mais abrangentes. 
Os educadores contemporâneos tratam a educação como um ajustamento do homem ao meio em que vive, para que ele saiba aceitar, compreender e reagir adequadamente às circunstâncias físicas, sociais e culturais do seu ambiente.

Fica evidente que os objetivos educacionais são bastante diversos no decorrer da história, pois refletem a situação econômica, social e política de cada época e as necessidades humanas desses períodos.

De acordo com a postura adotada pelos pedagogos contemporâneos, os fins da educação não podem se resumir numa preparação mecânica e conformista, através de um processo de aprendizagem passivo. Antes sim, esse processo deve ser dinâmico, ativo, progressivo, isto é, estar em constante ascensão, como a própria vida.

Assim se expressa Anísio Teixeira, um dos mais destacados pedagogos brasileiros: "Educação é vida, e viver é desenvolver-se, é crescer. Vida e crescimento não estão subordinados a nenhuma outra finalidade, salvo mais vida e mais crescimento. $O$ processo educativo, portanto, não tendo nenhum fim, além de si mesmo, é o processo de contínua reorganização, reconstrução e transformação da vida. O hábito de aprender diretamente da própria vida, e fazer que as condições da vida sejam tais que todos aprendam no processo de viver, é o produto mais rico que pode a escola alcançar. Graças a esse hábito, a educação, como reconstrução contínua da experiência, fica assegurada como atributo permanente da vida humana."

Enfim, a tentativa de se compreender e delimitar o termo "educação" vem desde o início do cristianismo, passando pela idade média, idade moderna e alcançando os tempos contemporâneos.

No Brasil, particularmente, a evolução do processo educacional iniciou-se em 1549, quando o primeiro Governador geral do Brasil, Tomé de Souza, desembarcou na Bahia. A partir do século XVIII, a educação brasileira, influenciada pelo movimento iluminista que inflamava a Europa, tomou novos rumos, chegando às proximidades do século XXI com sua mais recente proposta pautada no Plano Decenal de Educação para Todos 1993 a 2003 - e que busca dar continuidade nas ações educacionais, traçando metas a serem alcançadas a curto, médio e longo prazo. 
A história da educação no Brasil passa pelo modelo implantado pelos jesuítas e desmantelado pelo Marquês de Pombal; a criação de escolas durante o reinado de D. João VI, especialmente na Bahia e no Rio de Janeiro e destinadas a garantir a sobrevivência do sistema português; a liberdade de ensino prevista na Constituição outorgada de Pedro I; a utópica criação de escolas de primeiras letras em todas as cidades, vilas e lugarejos, previstas em 1827; a descentralização sem uma proposta de integração nacional; dentre outros fatos.

Segundo Niskier, o princípio federativo, que marcou a República, destruiu a tendência, levemente esboçada no regime que o antecedera, de um ensino visto como um todo organizado e harmônico. Depois de 30 (trinta) anos de implementado, a taxa de analfabetismo era de $75 \%$ entre a população total e de $65 \%$ entre a população adulta, taxa essa idêntica à de 1900. Nesse período, alguns Estados teriam aplicado apenas 3 a $5 \%$ de suas receitas com o ensino, mas, apesar disso, houve uma irradiação, embora difusa, da instrução.

A euforia de antes foi substituída pelo conservadorismo. A educação popular, desprezada pela classe dominante, encontrou seu lugar entre o proletariado urbano que começava a surgir. Nessa época surgem as primeiras escolas operárias, mantidas pelos sindicatos, e também as Escolas Modernas, inspiradas na pedagogia de Ferrer, educador espanhol. Pelo fato de as reivindicações populares ameaçarem o poder constituído, tais escolas não tiveram condições de sobreviver.

Com o fim da I Guerra Mundial, surge a influência norte-americana, não só na economia, com os princípios da Escola Nova disseminando-se entre os educadores mais progressistas e a educação começava a ser repensada. Cresce a ideia da educação como um todo organizado e harmônico, tendo sua expressão no Manifesto dos pioneiros da Educação Nova e em sua proposta de política educacional, sob a responsabilidade do Estado, com destaque para a organização da educação popular; a obrigatoriedade escolar; o acesso a todos os graus de ensino; a criação de Universidade e de Institutos; e a necessidade de definição dos meios para serem atingidos os fins. Todo este processo contou com a decisiva atuação da Associação Brasileira de Educação com suas Conferências Nacionais de Educação. 
Em 1934, são estabelecidos com a Constituição, pela primeira vez, princípios que as Cartas posteriores não puderam mais ignorar ou repudiar. Dentre os princípios, merecem ênfase a competência da União para privatizar e determinar as diretrizes da educação nacional; a fixação de um Plano Nacional de Educação; o direito de todos à educação; a gratuidade do ensino e sua obrigatoriedade; a criação de fundos especiais de educação, parte dos quais destinados aos mais necessitados.

A Constituição de 1937 abriu o ensino à iniciativa particular. Nessa época surge a forte tendência de conjugar o trabalho à educação, com a destinação clara do ensino profissional para as classes menos favorecidas, objetivando delinear as bases para a cooperação entre Estado, as indústrias e os sindicatos econômicos.

A Constituição de 1946 reafirmou os princípios das Constituições anteriores, em uma nova linguagem, definindo a competência do Estado para assumir o ensino, além de prever em percentuais o destino dos recursos para a Educação, sendo 10\% dos impostos recolhidos à União e reservados para esse fim e $20 \%$ dos recolhidos pelos Estados e municípios para seu desenvolvimento e manutenção.

Em 1961, a Lei 4.024 modificou o sistema educacional existente, contudo não criou um novo. Não obstante, a Lei incentivou a criação de currículos flexíveis, estabeleceu a competência do Conselho Federal de Educação, criado em 1962, e dos Conselhos Estaduais para estimularem métodos variáveis de instrução e formas diversas de atividades escolares.

Um forte anseio por melhor educação e as mudanças sociais provocadas pelo surto econômico trouxeram sucessivas alterações à Lei de Diretrizes e Bases da Educação Nacional (LDBEN). A Lei 5.540/68 (conhecida como a Reforma Universitária); o Decreto-Lei 464/69, complementando a Lei 5.540; a Lei 5.692/71 (relativa ao, então, $1^{\circ}$ e $2^{\circ}$ graus) e a Lei 7.044/82, que reformou o ensino profissionalizante, formam algumas das alterações que merecem destaque. Em 1970, é retomada, de forma gradativa, a Pedagogia Libertadora de Paulo Freire, sufocada em 1964.

Nas últimas décadas, as reformas educacionais têm buscado equalizar as oportunidades educacionais. Entretanto, cabe ressaltar, apesar das modernas técnicas didático- 
pedagógicas, ainda estamos distantes de atingir o processo ou modelo ideal de educação requerido e esperado pela sociedade brasileira.

Quando se fala de aprendizagem, é relevante salientar que, tanto a criança que se acha na fase de aquisição da linguagem, como o adolescente com dificuldade de ajustamento ou o adulto na distribuição de seu salário para as despesas domésticas, por exemplo, todos se encontram envolvidos com o processo de aprender os comportamentos adequados para a solução de seus problemas de vida. Assim, a aprendizagem vem ocupando, nos últimos tempos, o lugar que merece na preparação de professores, educadores, psicólogos e todos os profissionais cuja atuação se relaciona com modificações a serem operadas na personalidade humana.

Pode-se dizer que, na vida humana, a aprendizagem se inicia com o, ou até antes, do nascimento e se prolonga até a morte.

"Assim que nascemos, começamos a aprender e continuamos a fazê-lo durante toda a nossa vida. Com poucos dias, a criança já chama a mãe através do choro. Ao final do primeiro ano, familiariza-se com muitos dos objetos que formam seu novo mundo, adquire certo controle sobre suas mãos e pés e, ainda, torna-se perfeitamente iniciada no processo de aquisição da linguagem falada. Quando completa cinco ou seis anos, vai para a escola, onde, por meio de aprendizagem dirigida, adquire os hábitos, as habilidades, as informações, os conhecimentos e as atitudes que a sociedade considera essenciais ao bom cidadão".2

É através da aprendizagem que o homem melhora suas realizações nas tarefas manuais, a partir de seus erros, aprende a conhecer a natureza e a compreender seus companheiros. Ela capacita-o a ajustar-se adequadamente ao ambiente físico e social. Enfim, a aprendizagem leva o indivíduo a viver melhor ou pior, mas, indubitavelmente, a viver com o que aprende.

Com o passar dos tempos, através dos séculos e por meio da aprendizagem, as gerações foram capazes de aproveitarem das experiências e descobertas dos seus antecessores,

\footnotetext{
${ }^{2}$ Campos, Dinah M. Psicologia da Aprendizagem, $22^{\mathrm{a}}$ edicção, 1991 p.14.
} 
como também, por sua vez, oferecerem suas contribuições para o crescente patrimônio do conhecimento e das técnicas humanas. Como resultado da capacidade do homem de aprender, seus costumes, leis, religião, linguagem e instituições sociais têm se desenvolvido e perpetuado.

Os produtos dessa aprendizagem podem ser verificados nas obras de engenharia, dos cirurgiões, dos artistas etc. São ainda evidenciadas nas grandes descobertas e invenções da ciência moderna, na informática, no pensamento do filósofo e nas grandes decisões dos estadistas, apesar de algumas destas proporcionarem o sofrimento e a destruição da raça humana.

A aprendizagem é um processo tão importante para o sucesso da sobrevivência do homem que foram organizados meios educacionais e escolas para torná-la mais eficiente. Muitas das tarefas a que somos chamados a aprender, a exemplo de ler, usar uma escova de dente, somar, multiplicar, datilografar, demonstrar atitudes sociais, conduzir automóveis etc., não podem ser aprendidas naturalmente, como obra do acaso.

De acordo com a psicologia, o processo de aprendizagem e a maturação constituem as duas influências que mais afetam o comportamento humano.

\section{Concepções e Características ${ }^{3}$}

Segundo Sócrates, o conhecimento preexiste no espírito do homem e a aprendizagem consiste no despertar esses conhecimentos inatos e adormecidos.

Para Platão, autor da teoria dualista, que separava o corpo (ou coisa) da alma (ou ideias), a alma guarda a lembrança das ideias contempladas na encarnação anterior que, pela percepção, voltam à consciência.

Aristóteles apresenta um ponto de vista, definitivamente científico, ensina que todo conhecimento começa pelos sentidos, rejeitando a preexistência das ideias em nosso espírito. Foi o precursor do fundamento para o ensino intuitivo. Ao combater a

\footnotetext{
${ }^{3}$ Campos, Dinah M. Op cit., 1991.
} 
preexistência das ideias, formulou a célebre afirmação de que "nada está na inteligência que não tenha primeiro estado nos sentidos".

Santo Tomás de Aquino distinguiu as verdades científicas, baseadas na pesquisa e experimentação, e as verdades religiosas, baseadas na autoridade divina. Segundo ele, o principal agente da aprendizagem é a atividade de quem aprende.

Estas concepções foram evoluindo ao longo dos tempos e proporcionaram modificações nos métodos e processos de aquisição de conhecimentos.

Já no século XVII, Locke retoma o princípio aristotélico: "Nada está na inteligência que não tenha estado primeiro nos sentidos". Assim, combate a concepção das ideias inatas de Platão e insiste em que o espírito seria uma "tábua rasa". Combate também as ideias da "disciplina formal" ou a crença de que o espírito fosse formado por simples exercício de suas "faculdades". Nessa época, já admitiu a transferência e a generalização dos conhecimentos.

As ideias de Locke tiveram enorme influência direta e indireta sobre a compreensão psicológica da educação, na Inglaterra, na Alemanha e nos Estados Unidos da América do Norte.

Herbart (1776 - 1841) sistematizou muitas das ideias de Locke e estabeleceu a doutrina da "apercepção" e os "passos formais" do ensino (preparação, apresentação, associação, sistematização e aplicação). Herbart combatia a ideias das "faculdades" e desenvolvia as ideias da educação como fundamental na formação humana. Sua influência foi muito grande e ainda é patente nos trabalhos de Mac Murray, Morrison (autor do Plano de Unidades Didáticas).

Durante longo período do século XVIII, a pedagogia aceitou com entusiasmo o chamado "método intuitivo" de ensino com coisas ou das "lições de coisas". Já no final do século, Lloyd Morgan formulou a teoria de "ensaio - e - erro", aceita por Spencer, que havia introduzido o darwinismo na psicologia, acontecimento de grande importância nas teorias modernas de aprendizagem. 
Agora, ao invés do exercício intelectual, ou das ideias coloridas pela impressão das coisas (sensações, imagens, generalizações, ideias, juízo, raciocínio), começava-se a admitir a ação, os comportamentos como base de aprendizagem.

No Brasil, o movimento do "método intuitivo" refletiu-se com a tradução do livro de Calkins, "Lições de Coisas", feita por Rui Barbosa, e com as ideias de seus "pareceres" sobre o ensino, apresentados à Câmara dos Deputados, em 1882.

Por sua vez, a professora de psicologia Dinah Martins Souza diz que a aprendizagem pode ser entendida como uma classe de comportamento que consiste em uma modificação sistemática de conduta, advinda da repetição de uma mesma situação.

Analisando as definições de aprendizagem exibidas e outras, direciona-se para o entendimento de que a mais geral delas, e que abrange o pensamento da maioria dos autores, resume-se em: aprendizagem como uma modificação sistemática do comportamento ou da conduta, pelo exercício ou repetição, em função de condições ambientais e condições orgânicas. Verifica-se que a modificação do comportamento é uma variável dependente das condições ambientais e orgânicas, enquanto que estas se constituem em variáveis independentes, isto é, que ocorrem com o nosso controle ou não.

A aprendizagem envolve o uso e o desenvolvimento de todos os poderes, capacidades, potencialidades do homem, tanto físicas, quanto mentais e afetivas. Desta forma, não deve a mesma ser considerada somente como um processo de memorização ou que emprega apenas o conjunto das funções mentais ou unicamente os elementos físicos ou emocionais, pois todos estes aspectos são necessários.

\section{Características}

$\mathrm{Na}$ escola, o aluno aprende pela participação em atividades, a exemplo da leitura de textos, redações, resoluções de problemas, ouvindo explicações do professor, respondendo oralmente às questões, fazendo exames escritos, pesquisando, trabalhando nas oficinas, fazendo experiências em laboratório, atividades em grupo etc. Assim, a aprendizagem escolar depende não só do conteúdo dos livros, ou do que os professores 
ensinam, mas principalmente da reação dos alunos a determinados fatores, tais como os livros, ambiente social da escola, mestres etc. As utilizações destes métodos de ensino caracterizam a aprendizagem como sendo um processo dinâmico.

Este aspecto da dinamicidade do ensino deve ser cuidadosamente observado quando se pretende implementar a questão da educação de trânsito nas escolas, visto que a simples reprodução do material didático pelos órgãos de trânsito e seu envio para as escolas professores e alunos não garantem que a aprendizagem, geradora de mudança de atitudes e comportamento, ocorrerá.

Considerando a abordagem, já apresentada, de que desde o início da vida a aprendizagem se faz presente, da criança que suga o seio materno e enfrenta as dificuldades de coordenar os movimentos de sucção, deglutição e respiração ao indivíduo na idade escolar - adolescência, idade adulta ou em idade mais avançada - a aprendizagem está presente. Assim caracteriza-se a aprendizagem como sendo um processo contínuo.

A descontinuidade das ações de educação de trânsito tem sido, provavelmente, um de nossos maiores problemas para obter sucesso na aprendizagem tanto das crianças quanto dos adultos.

Pelo fato de incluir aspectos motores, emocionais e mentais, a aprendizagem que se propõe a gerar mudanças de atitudes e comportamento deve considerar a característica de ser global, com a finalidade de que os aspectos construtivos da personalidade do indivíduo entrem em atividade no ato de aprender.

Pode-se dizer que a aprendizagem caracteriza-se ainda por ser um processo pessoal e cumulativo. Ninguém pode aprender por outrem. As concepções antigas supunham que o professor, apresentando o conteúdo a ser aprendido, realizando os movimentos necessários, levava, obrigatoriamente, o aluno à aprendizagem. Hoje a compreensão do caráter pessoal da aprendizagem levou o ensino a concentrar-se na pessoa do aprendiz, tornando-se paidocêntrica (o aluno no centro) a orientação da escola moderna. Este aspecto, juntamente com os demais, leva-nos a crer que, quem aprende modifica atitudes e comportamento. 


\section{Produtos que resultam do processo ${ }^{4}$}

A aprendizagem, em geral, resulta em alguma mudança na atitude ou comportamento daquele que aprende. Deste modo, pode-se verificar alterações nas maneiras de agir, de fazer coisas, de pensar em relação às pessoas, de gostar ou não, de sentir-se atraído ou retraído pelos fatores emergentes do mundo em que vive.

Quando se observa uma criança, por exemplo, no início do aprendizado da escrita, vamos perceber que seu corpo fica todo tenso, dedos rígidos e que se firmam fortemente no lápis. À medida que vai praticando, capta os sinais que possibilitam movimentos mais flexíveis até se tornar capaz de manusear, mesmo uma caneta.

Por conseguinte, considera-se importante e necessário que o aprendiz seja apresentado às dificuldades de forma gradativa, para que possam ser percebidas e melhor automatizadas por ele. Em termos de educação para o trânsito, reforça-se a teoria de que o aprendizado deve iniciar já nas bases do ensino fundamental, quando a criança apresenta uma capacidade de assimilação e potencial de descobertas propícias para a introdução de novos conhecimentos.

É de conhecimento amplo, todavia, que, atualmente, a escola não tem por objetivos apenas a aprendizagem intelectual ou de automatismos. Ao contrário, pretende contribuir para a equilibrada formação da personalidade do aluno e sua integração ao ambiente sócio-cultural, através do ajustamento de seus sentimentos, atitudes e ideais aos do grupo a que o mesmo pertence. Diante deste novo conhecimento ou habilidade, a atitude do aprendiz pode variar, revelando-se positiva, negativa ou mesmo indiferente. Por isso, a aprendizagem apreciativa, emocional ou afetiva sempre acompanha as demais, ultrapassando o currículo escolar, seguindo pela vida afora. Quem aprende a dirigir um carro, aprendizagem tipicamente motora e automática, aprende, concomitantemente, a gostar ou não de dirigir carro, a respeitar as regras de trânsito, a tomar cuidado com a vida de outras pessoas, que formam um conjunto de aprendizagens apreciativas. Para a psicologia educacional, nunca se aprende uma só coisa de cada vez.

\footnotetext{
${ }^{4}$ Campos, Dinah M. Op cit., 1991.
} 
A aprendizagem apreciativa compreende atitudes e valores sociais, traduzidos por gostos, preferências, simpatias, costumes, crenças, hábitos e ideais de ação, que constituem os princípios mais gerais da conduta humana. Sem emoções, sentimentos, valores e ideais, a vida torna-se um tanto sem sentido. Sem essas reações, as palavras felicidade e desgraça, prazer e dor, amor e ódio seriam ininteligíveis; e, como tudo seria indiferente, os fatos mais catastróficos deixariam o homem completamente impassível. A este respeito, pode-se pensar sobre a impassividade do homem que assiste, todos os dias, a mortes e mutilações do seu semelhante no trânsito brasileiro e do mundo, assimilando tais ocorrências trágicas como meros acidentes, impossíveis de serem evitados.

É importante mencionar que a aprendizagem apreciativa resulta em respostas afetivas, podendo ser proveitosas ao indivíduo e à sociedade, se eliminadas as perniciosas, formando-se o hábito de experimentar sentimentos apropriados. Este tipo de aprendizagem possibilita a formação do caráter do aprendiz, o que se expressa na sua maneira constante de agir, diante das diferentes situações. Todo conteúdo da aprendizagem apreciativa, incluídos os de trânsito, que constitui os recursos fundamentais de integração à vida, ao meio social e à profissão, não surge espontaneamente, mas precisa ser ensinado e cultivado pela escola.

\section{Importantes questões a serem discutidas:}

- Como a aprendizagem apreciativa pode ser efetivada?

Enquanto a aprendizagem ideativa e motora pode submeter-se a regras e processos definidos, o mesmo não ocorre com a apreciativa, que ainda não dispõe de técnicas específicas.

Os valores, ideais, atitudes de apreciação etc., são, em parte, intelectuais. Daí poderem ser cultivados, em muitos casos, mediante aulas orientadas na base dos métodos de aprendizagem ideativa. Em outras situações, a aprendizagem apreciativa exige um ataque direto, através de exposições que provoquem resposta efetiva, atuando os processos de condicionamento. 
Os exercícios de apreciação, de formação de atitudes e preferências devem ser ocasionais, pois seria um tanto estranho, ou até mesmo complicado, assinalar no programa uma aula, por exemplo, sobre o gozo de uma obra de arte ou sobre o remorso produzido por uma ação má. Contudo, embora a aprendizagem de apreciação não deva ter lugar fixo nos horários, o cultivo dos valores, ideais e atitudes afetivas exige, frequentemente, estudos analíticos das ideias relacionadas com esses valores, ideais e atitudes.

Neste aspecto, um importante fator a ser considerado neste tipo de aprendizagem e que não deve ser deixado de ser cumprido é que o professor precisa vivenciar os ideais, atitudes e valores que deseja cultivar nos alunos; é difícil para um professor impulsivo inculcar nos alunos o valor do domínio de si mesmo, embora este preceito apresente menor aplicação quando os alunos forem mais velhos, já depois da adolescência.

O conjunto das disciplinas existentes hoje no ensino fundamental e, nos demais níveis de ensino, pode contribuir, significativamente, para uma mudança de atitude e comportamento dos usuários do sistema de trânsito no Brasil. Isto porque, todas as disciplinas oferecem campo ou espaço para se desenvolver a aprendizagem afetiva ou emocional.

\section{Qual a melhor idade para se aprender?}

$\mathrm{Na}$ opinião popular, tem-se a sensação de que o crescimento mental cessa aos $16 \mathrm{ou}$ 18 anos. Com base em resultados de investigações experimentais, os psicólogos não mantêm esta regra. A capacidade para aprender, de acordo com a psicóloga Dinah Martins Campos, continua a desenvolver-se, com bastante intensidade, até cerca de 23 anos de idade. Daí até os 40 anos parece haver um platô. Em seguida, nota-se um declínio na proporção de 0,5 a $1 \%$ anual da capacidade exibida na casa dos 20 anos, que chega, aproximadamente, a $15 \%$ no máximo.

\section{Motivar na aprendizagem é importante?}


O valor da motivação tem sido realçado em todos os campos da psicologia aplicada, isto porque a afirmação de Young, em 1936, de que "todo comportamento é motivado", vem sendo constatada pelos estudiosos do problema, embora seja ainda passível de discussão. Não se tem dúvida de que os motivos constituem o aspecto dinâmico do processo educacional e representam um dos pré-requisitos mais importantes da aprendizagem na escola.

Parcela significativa das dificuldades da escola tem sua origem nos problemas da motivação, ou seja, na tarefa de diagnosticar os interesses e necessidades dos alunos; na consideração das diferenças individuais; na organização das atividades extracurriculares; nos problemas de aprendizagem, propriamente ditos; nas questões básicas de reconhecimento do trabalho dos professores etc.

Entretanto, ainda não se sabe, com certeza, como os motivos operam. Sabe-se apenas que exercem uma poderosa influência sobre a aprendizagem, colocando em ação todas as forças necessárias para que a mesma se processe.

A palavra motivo vem do latim "movere, motum" e significa aquilo que faz mover. Em consequência, motivar é o mesmo que provocar movimento, atividade no indivíduo. Os motivos podem ser classificados de acordo com vários critérios, tais como:

a) Quanto à natureza - podem ser biológicos (fome, sono, sede, etc.); psicológicos (autoexpressão, afeição, medo, raiva, curiosidade, etc.); sociais (desejo de autoafirmação, de liderança, de aprovação social, de se associar aos outros, etc).

b) Quanto à duração - podem ser incidentais, transitórios e superficiais (condicionam a atitude e a conduta do indivíduo durante algumas horas, ou alguns dias, sem repercussões mais profundas na personalidade); podem ser permanentes, profundos e intensos (orientam a vida do indivíduo desde a infância até a morte).

c) Quanto à intensidade - podem ser intensos e violentos, com forte carga emocional, ou frios e calculados, sem grande pressão emocional, mas 
persistentes e sistemáticos. Neste aspecto, podemos refletir sobre a forma de se introduzir os conteúdos de trânsito nas escolas, se utilizando as dramáticas informações estatísticas - tratamento de choque - ou transmitindo um conceito ampliado de trânsito como deslocamentos.

É fundamental destacar que o professor, na qualidade de orientador das atividades do aluno, é o mediador entre os motivos individuais e os legítimos alvos a serem alcançados. Mais do que isto, compete ao mestre, como agente socializador, incutir os padrões da cultura, ou seja, novos motivos. Desta forma, o educando poderá desenvolver tipos de atitudes e comportamento que garantam um ajustamento social eficiente.

\section{Quais os efeitos advindos do processo de motivação utilizado?}

a) Positivo - quando a motivação resulta do emprego de recursos motivadores que não trarão perturbações na personalidade do aprendiz, como, por exemplo, o elogio, o envolvimento do ego etc.

b) Negativo - é a motivação que conduz à aprendizagem, sendo, porém, antipsicológica e deseducativa, porque traz perturbações à personalidade do aluno. Assim, por exemplo, o castigo e a ameaça constituem incentivos eficazes, mas levam o aluno a se tornar inseguro, tímido, covarde, violento etc.

Neste sentido, deve-se ter especial atenção na forma como os conteúdos de trânsito serão disseminados nas escolas, o que levará, posteriormente, a uma reflexão sobre a questão da transversalidade, definida nos parâmetros curriculares e que abrem espaço para que o professor possa trabalhar diferentes assuntos, como o trânsito, dentro de sala de aula.

\subsection{Aspectos Sociológicos: ser humano, sociedade, veículo e infraestrutura}

O estudo sociológico da educação iniciou-se no Brasil sob os mais felizes auspícios. Contando com a compreensão dos pioneiros da nossa renovação escolar, inaugurada 
como área de pesquisa autóctone pela monumental obra de Fernando de Azevedo, cedo introduzida nos currículos dos cursos de formação pedagógica, a Sociologia da Educação parecia destinada a trazer a contribuição que lhe cabe fazer ao progresso nacional: a de iluminar a realidade, para que a Pedagogia pise em terreno firme. Entretanto, quem observa o dia a dia do ensino não pode deixar de reconhecer que o cumprimento das promessas da Sociologia ficou aquém das esperanças inicialmente por ela despertadas. A sua repercussão na prática escolar, quer educativa, quer administrativa, é modesta.

A mudança cultural precipita-se, na época atual, com vertiginosa rapidez. Isto confronta as sociedades modernas com a necessidade de rever as doutrinas orientadoras da sua prática educacional, porque, nascidas em determinados períodos históricos, refletem os problemas e as soluções peculiares deles. Precisamente por desejarem manter a identidade da sua cultura, os povos não podem subtrair-se ao desafio do momento presente: a tradição abriga em seu seio os valores a cuja manutenção aspiram, mas concretiza-os sob formas condicionadas por situações sociais passadas; oferece meios para a sua consecução, possivelmente adequados às circunstâncias que os produziram, mas cuja eficácia precisa ser reavaliada quando os reclamos e recursos ambientais se modificam. Na educação presente, o passado encontra-se com o futuro e esta tríplice perspectiva é repleta de incertezas, as quais, ao ser humano moderno, repugnam disfarçar. Quer se saber o que quer, por que se quer, e como pode atingir os objetivos.

Pode-se admitir que a sociologia, ao estudar a sociedade, tem por objeto investigar as forças em interação, os processos sociais, os fatores de mudança, os seus mecanismos de organização ou de desorganização. A sociologia é, realmente, um estudo positivo dos fatos inter-humanos nas suas relações com a vida coletiva, dos seus comportamentos e tendências, e das formas de associação e mudança.

Assim sendo, a sociologia corresponde a um ponto de vista que se encontra em qualquer atividade do homem, e sempre engajado num quadro cultural. E, como a vida social penetra o homem na sua totalidade, não há nenhuma forma da atividade humana que escape à sociologia, incluindo a educação para o trânsito. 
Em toda cultura encontra-se o mecanismo de sua perpetuação sob a forma de certas normas de ação. Estas determinam algumas relações básicas entre pais e filhos, entre jovens e velhos, entre mestres e discípulos. Neste contexto, o caráter institucional da educação torna-se cada vez mais nítido, manifestando-se, finalmente, na sua forma mais concreta, que é a escola. Deve-se, portanto, considerar que a educação é parte integrante das culturas humanas e mecanismo das próprias culturas. Nenhum fenômeno cultural sobrevive sem que lhe corresponda um processo ininterrupto de aprendizagem.

A educação é cada vez mais necessária para preparar os indivíduos para um mundo em mudança permanente, e não para um mundo estático. É sob esse aspecto que se deve compreender a educação em face da ordem social: nas sociedades modernas, a educação formal age como uma maneira de comunicar, independentemente, ideias e valores que desempenham um papel de regulamentação do comportamento.

Através da educação, as novas gerações aprendem as normas sociais e as sanções pela sua não observância. Nas sociedades modernas, onde a educação formal se torna predominante, e onde um grupo ocupacional importante de professores passou a existir, ela se tornou um dos tipos principais de controle social.

Uma ordem social democrática depende da educação. No trânsito não é diferente. $O$ principal objetivo é o de desenvolver personalidades, e preparar seres humanos para funções úteis na sociedade. Neste caso, o mero conhecimento das regras não será suficiente. Torna-se inadequada a educação que não desenvolva e apreste o indivíduo para enfrentar eficientemente as contingências múltiplas da vida. A educação deve desenvolver as potencialidades do homem a fim de que possa pensar com clareza, compreender e apreciar os valores sociais, adquirir habilitações e lograr resultados.

Quando se pensa o indivíduo inserido em uma sociedade, é preciso também lembrar que existem ações externas que interferem diretamente na formação e na construção de valores das pessoas. Assim, o veículo, cuja indústria transformou em um objeto de desejo e necessidade extrema no dia a dia do ser humano, apresenta-se como um fator significativo a ser observado quando se estuda o sistema de trânsito. Através do marketing e da propaganda, o veículo subiu montanhas, atravessou rios, superou obstáculos intransponíveis e atingiu o ego e o subconsciente das pessoas para a 
aquisição e o uso, nem sempre adequado, da máquina. Neste momento, o deslocamento deixa de ser o foco principal do uso do veículo, passando a prioridade para o "status", o poder, a força, a potência, a sexualidade, a beleza, a modernidade e, muitas vezes, leva o indivíduo a romper com a lógica do viver em sociedade.

Por outro lado, a engenharia corre atrás de prover infraestrutura para possibilitar e facilitar o deslocamento dos veículos e pedestres, sabendo que a distribuição do espaço urbano para este fim requer políticas de priorização. Na prática, observa-se que o espaço urbano das cidades foi e está sendo constituído para uso intensificado do veículo individual, deixando a desejar os caminhos destinados ao uso da pessoa, do ser humano. Então, torna-se pouco evitável o conflito entre o homem e a máquina na utilização deste espaço público e todos, ser humano - veículo - infraestrutura, se tornam potenciais fatores que se relacionam como protagonistas dos aspectos negativos no trânsito.

Segundo FILHO (2004), “a preocupação primeira com a segurança no trânsito não pode estar restrita aos fatores mais imediatamente visíveis nos conflitos, mas considerar todo o contexto que gera o estado de coisas que se deseja transformar. Agindo na dimensão social da questão, reconhecendo os elementos que, de fato, estão "por trás" dos conflitos, tem-se uma oportunidade de se interferir de forma efetiva na realidade do trânsito."

\subsection{Educação para o trânsito}

\section{A questão da educação de trânsito no Brasil pode ser analisada sob diferentes aspetos que envolvem a legislação, o plano político-educacional e o cultural.}

Conforme BRAGA \& SANTOS (1995), “a área de segurança de tráfego ultrapassou, há muito, a fase na qual a prevenção dos acidentes de trânsito era tratada sob um aspecto exclusivo ligado à construção de vias e à engenharia de tráfego. Hoje, ela é compreendida como multidisciplinar, e prevenir acidentes e suas conseqüências envolve desde o projeto dos veículos até o atendimento às vítimas". 
Considerando o histórico das normas brasileiras que citam o aspecto da educação voltada para a segurança no trânsito, encontra-se, a partir da Constituição Federativa do Brasil, datada de 1988:

Art. 205. "A educação, direito de todos e dever do Estado e da família, será promovida e incentivada com a colaboração da sociedade, visando ao pleno desenvolvimento da pessoa, seu preparo para o exercício da cidadania e sua ampliação para o trabalho."

Art. 23, XII "Competência comum da União, dos Estados, do Distrito Federal e dos Municípios: estabelecer e implantar política de educação para a segurança do trânsito".

\section{7 - Lei n 9.503, CTB - Código de Trânsito Brasileiro}

\section{Capítulo I - Disposições preliminares}

Art. $1 \S 2^{\circ} \mathrm{O}$ trânsito, em condições seguras, é um direito de todos e dever dos órgãos e entidades componentes do Sistema Nacional de Trânsito, a estes cabendo, no âmbito das respectivas competências, adotar as medidas destinadas a assegurar esse direito.

$\S^{\circ}$ Os órgãos e entidades componentes do Sistema Nacional de Trânsito respondem, no âmbito das respectivas competências, objetivamente por danos causados aos cidadãos em virtude de ação, omissão ou erro na execução e manutenção de programas, projetos e serviços que garantam o exercício do direito do trânsito seguro.

\$5 $5^{\circ}$ Os órgãos e entidades pertencentes ao Sistema Nacional de Trânsito darão prioridade em suas ações à defesa da vida, nela incluída a preservação da saúde e do meio ambiente.

\section{Capítulo V-Do Cidadão}

Art. 72 . Todo cidadão ou entidade civil tem o direito de solicitar por escrito, aos órgãos ou entidades do Sistema Nacional de Trânsito, sinalização, fiscalização e implantação de equipamentos de segurança, bem como sugerir alterações em normas, legislação e outros assuntos pertinentes a este código. 
Art. 73. Os órgãos ou entidades pertencentes ao Sistema Nacional de Trânsito têm o dever de analisar as solicitações e responder, por escrito, dentro de prazos mínimos, sobre a possibilidade ou não de atendimento, esclarecendo ou justificando a análise efetuada, e, se pertinente, informando ao solicitante quando tal evento ocorrerá.

Parágrafo único: As campanhas de trânsito devem esclarecer quais as atribuições dos órgãos e entidades pertencentes ao Sistema Nacional de Trânsito e como proceder a tais solicitações.

\section{Capítulo VI - Da Educação para o Trânsito}

Art. 74 "A educação para o trânsito é direito de todos e constitui dever prioritário para os componentes do Sistema Nacional de Trânsito. É obrigatória a existência de coordenação educacional em cada órgão ou entidade componente do Sistema Nacional de Trânsito, que deverão promover, dentro de sua estrutura ou mediante convênio, o funcionamento de Escolas Públicas de Trânsito.”

Art. 75 Campanhas de âmbito nacional deverão ser promovidas por todos os órgãos e entidades do Sistema Nacional de Trânsito.

Art. 76 "A educação para o trânsito será promovida na pré-escola e nas escolas de ensino fundamental, básico e III graus, por meio de planejamento e ações coordenadas entre os órgãos e entidades do Sistema Nacional de Trânsito e de Educação, da União, dos Estados, do Distrito Federal e dos Municípios, nas respectivas áreas de atuação".

Parágrafo único: “...mediante proposta do CONTRAN e do Conselho de Reitores das Universidades Brasileiras, diretamente ou mediante convênio promoverá:

I - adoção, em todos os níveis de ensino, de um currículo interdisciplinar com conteúdo programático sobre segurança no trânsito; 
II - adoção relativos à educação para o trânsito nas escolas de formação do magistério e o treinamento de professores e multiplicadores;

III - criação de corpos técnicos interprofissionais para levantamento e análise de dados estatísticos relativos ao trânsito;

IV- elaboração de planos de redução de acidentes de trânsito junto aos núcleos interdisciplinares universitários, com vistas à integração universidades-sociedade na área de trânsito “.

Art.77. No âmbito da educação para o trânsito, caberá ao Ministério da Saúde, mediante proposta do CONTRAN, estabelecer campanha nacional esclarecendo condutas a serem seguidas nos primeiros socorros em caso de acidente de trânsito.

Parágrafo único. As campanhas terão caráter permanente por intermédio do Sistema Único de Saúde - SUS, sendo intensificadas nos períodos e nas formas estabelecidas no artigo 76.

Art. 78 "Os Ministérios as Saúde, da Educação, do Desporto, do Trabalho, dos Transportes e da Justiça, por intermédio do CONTRAN, desenvolverão e implementarão programas destinados à prevenção de acidentes”.

Parágrafo único "O percentual de $10 \%$ total dos valores arrecadados destinados à Previdência Social, do Prêmio do Seguro Obrigatório de Danos Pessoais causados por Veículos Automotores da Via Terrestre, será repassado mensalmente ao coordenador do Sistema Nacional de Trânsito para aplicação exclusiva em programas de que trata este artigo".

Art. 320 "A receita arrecadada com a cobrança das multas de trânsito será aplicada, exclusivamente, em sinalização, engenharia de tráfego, de campo, policiamento, fiscalização e educação de trânsito". 
Parágrafo único. O percentual de 5\% do valor das multas de trânsito arrecadadas será depositado, mensalmente, na conta do fundo de âmbito nacional destinado à segurança e educação de trânsito.

No plano político-educacional e também cultural, pode-se pensar nas possibilidades de trabalho e ações efetivas de educar para o trânsito partindo do conceito básico dos "temas transversais" definido pela legislação educacional brasileira através da criação dos Parâmetros Curriculares Nacionais (PCN).

Ao definir os temas a serem trabalhados na transversalidade, o Ministério da Educação levou em consideração os seguintes critérios:

- Urgência social Questões graves, que se apresentam como obstáculos para a concretização da plenitude da cidadania, afrontando a dignidade das pessoas e deteriorando sua qualidade de vida.

- Abrangência nacional

Questões que são pertinentes a todo o país.

- Possibilidade de ensino e aprendizagem no ensino fundamental

A experiência pedagógica brasileira, ainda de modo não uniforme, indica essa possibilidade, em especial no que se refere à Educação para a Saúde, Educação Ambiental e Orientação Sexual, já desenvolvidas em muitas escolas.

- Favorecer a compreensão da realidade e a participação social É a expressão da finalidade última dos Temas Transversais, onde os alunos possam desenvolver a capacidade de posicionar-se diante das questões que interferem na vida coletiva, superar a indiferença, intervir de forma responsável.

Assim, os temas eleitos, em conjunto, devem possibilitar uma visão ampla e consistente da realidade brasileira e sua inserção no mundo, além de 
desenvolver um trabalho educativo que possibilite uma participação social dos alunos.

Dentre os objetivos propostos nos Parâmetros Curriculares Nacionais, estão as intenções educativas em termos de capacidades que devem ser desenvolvidas pelos alunos ao longo da escolaridade. Esta decisão é considerada fundamental na proposta, pois as capacidades, uma vez desenvolvidas, podem expressar numa variedade de comportamentos. O professor, consciente de que condutas diversas podem estar vinculadas ao desenvolvimento de uma mesma capacidade, tem diante de si maiores possibilidades de atender à diversidade de seus alunos. Desta forma, os objetivos se definem em termos de capacidades de ordem cognitiva, física, afetiva, de relação interpessoal e inserção social, ética e estética, tendo em vista uma formação ampla.

Importante salientar que, dentro dos objetivos estabelecidos pelos Parâmetros, é perfeitamente possível e justificável a introdução da temática trânsito para os alunos.

Em relação aos conteúdos apresentados pelos Parâmetros, percebe-se uma mudança de enfoque comparativo aos conteúdos curriculares. Ao invés de um ensino em que o conteúdo seja visto como fim em si mesmo, o proposto é um ensino no qual o conteúdo seja considerado como meio para que os alunos desenvolvam as capacidades que lhes permitam produzir e usufruir dos bens culturais, sociais e econômicos.

Dentro do projeto educacional, verifica-se a demanda por uma reflexão em que a noção de conteúdo escolar se amplia para além de fatos e conceitos, passando a incluir procedimentos, valores, normas e atitudes. Ao tomar como objeto de aprendizagem escolar conteúdos de diferentes naturezas, reafirma-se a responsabilidade da escola com a formação ampla do aluno e a necessidade de intervenções conscientes e planejadas nessa direção.

O que se pretende com a introdução da educação para o trânsito na escola é, exatamente, garantir procedimentos e formação de valores de cidadania que levem o aluno de hoje (pedestre, passageiro) ou o indivíduo de amanhã (também motorista) a 
mostrarem atitudes compatíveis com a segurança e o respeito mútuo com os diversos usuários do sistema de trânsito, independentemente da forma como se locomovem.

Na visão de PEREIRA (2002), a educação para o trânsito é o processo de desenvolvimento da capacidade física, cognitiva, afetiva e moral da criança e do ser humano em geral, visando a sua melhor integração individual e social. Acredita que esta aprendizagem deve levar à formação de cidadãos autônomos, críticos e participativos, capazes de atuar com competência, dignidade e responsabilidade na sociedade em que vivem e na qual esperam ver atendidas suas necessidades individuais, sociais, políticas e econômicas.

\subsection{Outras áreas de interferência}

Quando se trata do tema trânsito, muitas outras áreas do conhecimento podem ser mencionadas, com efeitos e interferências diretas ou indiretas na segurança da circulação humana e de veículos. Frequentemente destacam-se: a educação, a engenharia de tráfego, a comunicação visual (referente à comunicação nas vias), a mecânica, a medicina preventiva e de atendimento a acidentados, dentre outras.

Assim, o sistema de trânsito requer o envolvimento de diferentes áreas do conhecimento em ações conjuntas. Não bastam as técnicas e tecnologias da engenharia ou os princípios norteadores da educação, ou ainda o braço forte da fiscalização. Se estas áreas, como outras, não estiverem em sintonia na ação do sistema viário, não se tem um bom funcionamento do sistema de trânsito.

Não se tem dúvidas do quanto a sociedade necessita da engenharia no seu cotidiano, o que demonstra ou evidencia o importante papel que esta tem desempenhado ao longo da história da humanidade. A engenharia e os engenheiros vêm contribuindo para que o homem desenvolva seu trabalho de forma menos árdua e conquiste uma vida mais confortável e com maior qualidade.

Quando se pauta pelo que ocorre no trânsito brasileiro, e, de certa forma no mundo com mais ou menos intensidade -, constata-se que o fenômeno do trânsito é, por 
natureza, multidisciplinar. Que a solução dos problemas advém da soma da ação das diferentes áreas do conhecimento, e a engenharia e a educação são de extrema importância. 


\section{4 \\ O PROJETO RUMO À ESCOLA}

\subsection{A parceria Denatran / Unesco para a educação de trânsito}

Com vistas a implementar um trabalho efetivo de educação para o trânsito no ensino fundamental, utilizando-se da transversalidade do tema, foi realizada a primeira grande experiência e pesquisa no Brasil com a parceria da Unesco e execução do Denatran do projeto denominado Rumo à Escola.

O Projeto Rumo à Escola considerou os seguintes critérios na escolha dos Estados participantes. Partindo do princípio que diversas variáveis influenciam na temática do trânsito e da educação, foram elencadas dezesseis destas, a saber:

1. população;

2. frota veicular;

3. mortos no trânsito;

4. feridos;

5. motorização;

6. mortos por 10.000 veículos;

7. mortos por 100.000 habitantes;

8. acidentes por 1.000 veículos;

9. percentual de participação dos municípios integrados ao Sistema Nacional de Trânsito - SNT;

10. número total de municípios integrados ao SNT;

11. número de alunos da rede municipal no Estado;

12. número de alunos da rede municipal nos municípios integrados ao SNT;

13. participação percentual do número de alunos matriculados nos municípios integrados ao SNT em relação ao total do Estado;

14. taxa de crescimento populacional (1995/1998);

15. taxa de crescimento do número de mortos por 10.000 veículos (1995/1998);

16. taxa de crescimento da frota veicular (1996/1998). 
Fazendo uma análise de componentes principais, notou-se que apenas cinco variáveis seriam suficientes para explicar as variações observadas entre os Estados, uma vez que algumas delas estavam autocorrelacionadas. Deste modo, foram selecionadas:

Var 1. Percentual de Municípios integrados ao SNT em relação ao total de municípios existentes no Estado em 2.000;

Var 2. Mortos por 10.000 veículos no Estado, ano de 1998;

Var 3. Mortos por 100.000 habitantes no Estado, ano de 1998;

Var 4. Acidentes por 10.000 veículos no Estado, ano de 1998;

Var 5. Participação percentual da matrícula municipal de alunos dos municípios integrados ao SNT em relação à matrícula total do Estado, ano de 1998.

Ficou definido como Estados preferenciais para seleção os que exibiram as taxas mais altas em todas as variáveis de análise. Então, a prioridade de escolha recaiu sobre os Estados em que o agregado de índices foi maximizado. Como as bases de comparação eram diferenciadas, todos os índices foram adequados em função da base 100, ficando estabelecida a primeira representação dos Estados em função dos índices obtidos, conforme demonstrado na tabela 4.1, apresentada abaixo. 
Tabela 4.1 Representação, por Estado, dos índices obtidos nas variáveis. Fonte: Projeto Rumo à Escola

\begin{tabular}{|c|c|c|c|c|c|}
\hline Estado & Var 1 & Var 2 & Var 3 & Var 4 & Var 5 \\
\hline Alagoas & 3,96 & 0,16 & 0,01 & 0,07 & 15,87 \\
\hline Amapá & 12,5 & 0,23 & 0,02 & 0,15 & 52,98 \\
\hline Amazonas & 1,61 & 0,15 & 0,01 & 0,06 & 42,49 \\
\hline Bahia & 0,72 & 0,21 & 0,01 & 0,13 & 7,37 \\
\hline Ceará & 3,80 & 0,15 & 0,01 & 0,08 & 22,44 \\
\hline * Distrito Federal & 6,47 & 0,06 & 0,02 & 0,07 & 100 \\
\hline Espírito Santo & 6,49 & 0,09 & 0,01 & 0,11 & 41,38 \\
\hline Goiás & 2,07 & 0,07 & 0,01 & 0,06 & 32,37 \\
\hline Maranhão & 1,84 & 0,20 & 0,01 & 0,08 & 10,48 \\
\hline Minas Gerais & 0,70 & 0,06 & 0,01 & 0,13 & 17,55 \\
\hline Mato Grosso & 4,76 & 0,05 & 0,01 & 0,07 & 33,46 \\
\hline Mato Grosso do Sul & 14,29 & 0,08 & 0,01 & 0,10 & 50,93 \\
\hline Pará & 3,50 & 0,35 & 0,02 & 0,16 & 13,70 \\
\hline Paraíba & 5,38 & 0,06 & 0,004 & 0,18 & 23,42 \\
\hline Pernambuco & 13 & 0,03 & 0,003 & 0,05 & 67 \\
\hline Piauí & 0,45 & 0,14 & 0,01 & 0,07 & 12,97 \\
\hline Paraná & 1,62 & 0,08 & 0,02 & 0,36 & 16,67 \\
\hline Rio de Janeiro & 37,36 & 0,01 & 0,003 & 0,02 & 83,74 \\
\hline Rio Grande do Sul & 8,14 & 0,04 & 0,01 & 0,07 & 33,18 \\
\hline Rio Grande do Norte & 7,23 & 0,19 & 0,02 & 0,13 & 27,15 \\
\hline Roraima & 6,66 & 0,20 & 0,03 & 0,09 & 1 \\
\hline Santa Catarina & 1,71 & 0,07 & 0,02 & 0,18 & 19,36 \\
\hline São Paulo & 15,19 & 0,04 & 0,01 & 0,07 & 76,96 \\
\hline Sergipe & 1,33 & 0,21 & 0,02 & 0,04 & 12,47 \\
\hline Tocantins & 0,71 & 0,15 & 0,01 & 0,16 & 4,86 \\
\hline
\end{tabular}

* A base utilizada para calcular o índice percentual do Distrito Federal - uma vez que possui apenas um município - fundamentou-se nos mesmos referenciais utilizados às demais Unidades da Federação, a fim de evitar possíveis distorções que pudessem desfavorecer a inclusão do DF no projeto.

Definidos os índices obtidos, por variável, em cada Estado, foi estabelecida a nova composição, considerando os índices agregados e priorizando os Estados que atingiram maiores valores, conforme demonstrado na tabela 4.2, abaixo. 
Tabela 4.2 - Composição, por Estado, de índices agregados. Fonte: Projeto Rumo à Escola

\begin{tabular}{|l|l|}
\hline \multicolumn{1}{|c|}{ Estado ${ }^{*}$ ) } & \multicolumn{1}{|c|}{ Ídice Agregado } \\
\hline 11. Alagoas & 0,0087 \\
\hline 1. Amapá & 0,4745 \\
\hline 12. Amazonas & 0,0079 \\
\hline Bahia & 0,0019 \\
\hline 9. Ceará & 0,0000 \\
\hline 4. Distrito Federal & 0,0540 \\
\hline 7. Espírito Santo & 0,0403 \\
\hline Goiás & 0,0037 \\
\hline Maranhão & 0,0025 \\
\hline Minas Gerais & 0,0011 \\
\hline Mato Grosso & 0,0047 \\
\hline 3. Mato Grosso do Sul & 0,0751 \\
\hline 6. Pará & 0,0443 \\
\hline 14. Paraíba & 0,0062 \\
\hline 15. Pernambuco & 0,0039 \\
\hline Piauí & 0,0005 \\
\hline 8. Paraná & 0,0155 \\
\hline Rio de Janeiro & 0,0017 \\
\hline 10. Rio Grande do Sul & 0,0103 \\
\hline 2. Rio Grande do Norte & 0,0908 \\
\hline Roraima & 0,0033 \\
\hline 13. Santa Catarina & 0,0077 \\
\hline 5. São Paulo & 0,0531 \\
\hline Sergipe & 0,0034 \\
\hline Tocantins & $\mathbf{0 , 0 0 0 6}$ \\
\hline & \\
\hline
\end{tabular}

(*) A numeração corresponde aos Estados selecionados, em ordem de maior índice agregado.

O Projeto foi implementado nas capitais dos Estados selecionados: São Paulo; Vitória; Recife; Fortaleza; João Pessoa; Maceió; Natal; Belém; Manaus; Macapá; Brasília; Campo Grande; Porto Alegre; Curitiba; Florianópolis.

Em cada capital foi efetivado trabalho com quinze escolas de ensino fundamental, sendo cinco da rede estadual, cinco da rede municipal e cinco da rede particular. A definição das Escolas se deu em função do número de alunos matriculados (maiores 
quantitativos), considerando dados fornecidos pelo Ministério da Educação e pelas Secretarias de Educação dos Estados, ano base 1998.

O projeto atendeu a 225 (duzentas e vinte cinco) escolas, cerca de 19.000 (dezenove mil) professores e de 280.000 (duzentos e oitenta mil) alunos do ensino fundamental, do primeiro ao último ano. A estrutura organizacional do Projeto encontra-se demonstrada na figura 4.1, apresentada abaixo.

\section{ESTRUTURA DO RUMO À ESCOLA}

Antes de qualquer assunto relacionado ao trabalho com o tema trânsito em sala de aula, é preciso que vocè saiba como funciona o Projeto RUMO À ESCOLA.

Observe:

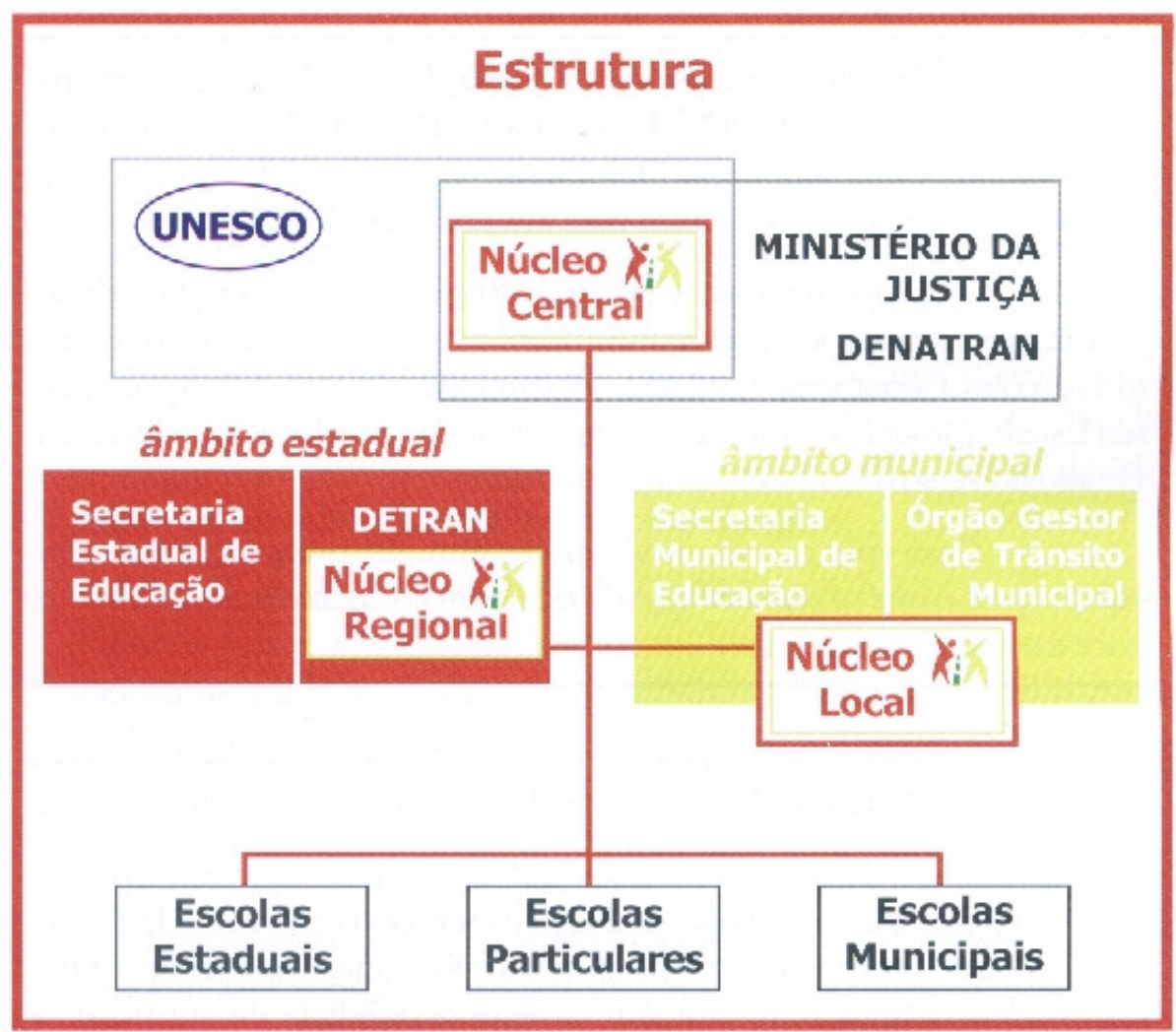

() Projeto conta com profissionais especializados, formando uma rede ágil ce integrada para atender às escolas.

Fique ligado ao trabalho de cada Núcleo!

Figura 4.1. Estrutura organizacional do Projeto Rumo à Escola 
O Projeto definiu o "slogan" e a capa, conforme apresentado na figura 4.2, abaixo.

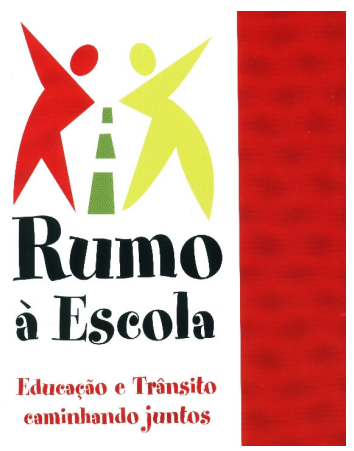

Figura 4.2. Capa e slogan do projeto

Os Estados selecionados e onde se implementou o Projeto Rumo à Escola encontram-se demonstrados no mapa da figura 4.3, apresentada a abaixo.

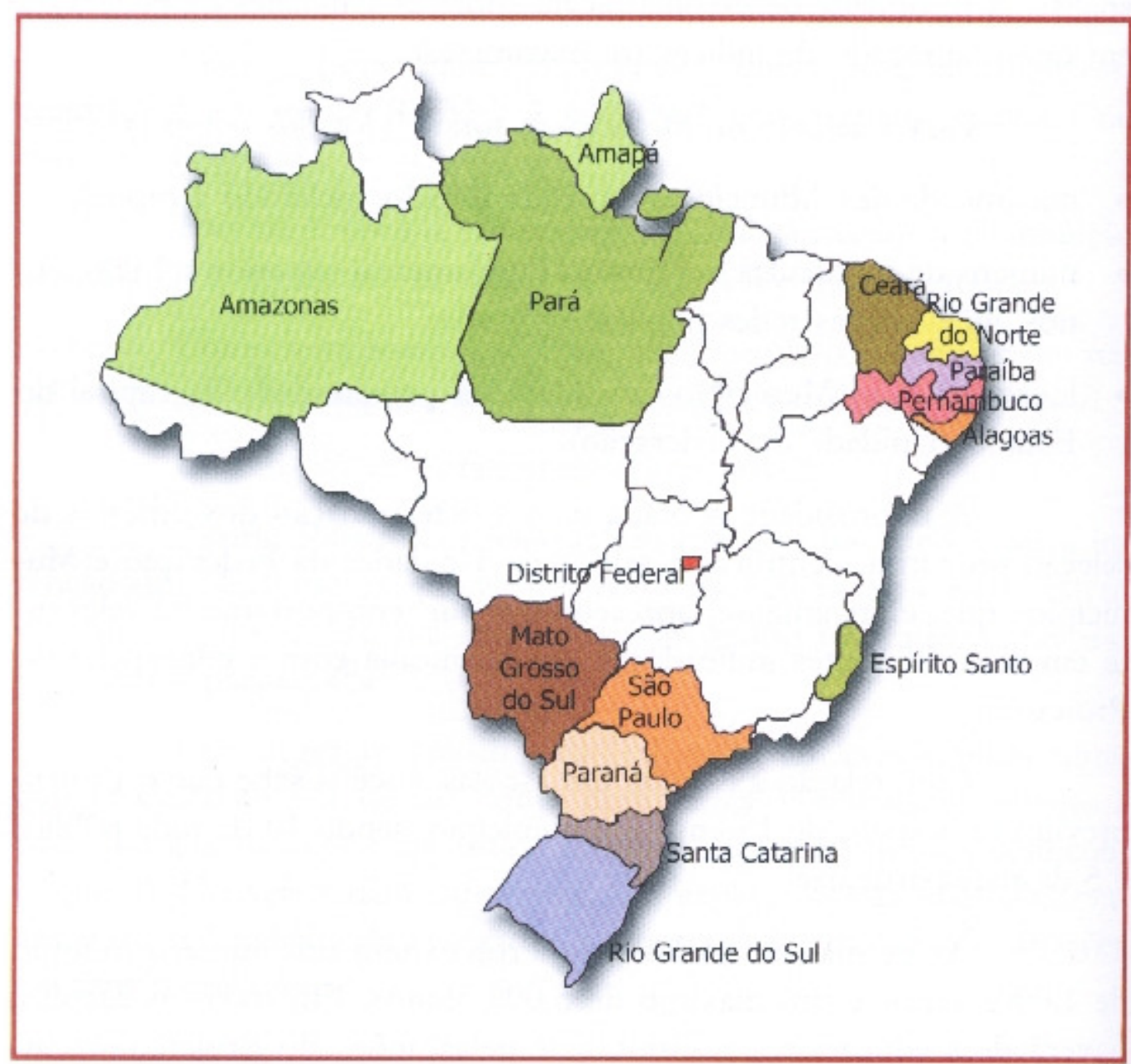

Figura 4.3. Mapa com a localização dos Estados participantes do Projeto 
Em relação à equipe de profissionais que atuou no Projeto e na pesquisa de campo o processo seletivo observou os seguintes critérios:

- graduação superior;

- disponibilidade para deslocamentos;

- experiência comprovada na área de educação e do trânsito;

- conhecimentos na área de informática;

- residência na capital de implementação do projeto

Ao todo, foram selecionados trinta e dois técnicos, sendo dois para cada capital, excetuando-se São Paulo e Brasília, que tiveram três profissionais cada.

\section{Livro do Professor}

Este recurso didático utilizado pelo Projeto objetivou apresentar ao professor a filosofia base do Rumo à Escola e, ao mesmo tempo, introduzir conceitos diferenciados sobre trânsito, transversalização da matéria e dar orientações de como os professores poderiam introduzir o tema dentro de suas disciplinas específicas.

Assim, considerando a configuração apresentada, pode-se dizer que o Projeto Rumo à Escola se tornou um marco para a questão da educação de trânsito no Ensino Fundamental, implementada pela União no Brasil.

Ao constituir equipe técnica nos Estados para fazer o acompanhamento e a orientação dos professores junto às escolas, o Projeto rompeu com o tradicional hábito dos organismos de trânsito de apenas distribuir materiais técnicos. Conseguiu avaliar, passo a passo, o processo de implementação e resultados do Projeto. Observa-se que, mesmo passados sete anos do encerramento do projeto, ocorrido em 2004, muitas das escolas que fizeram parte do Projeto continuam trabalhando o tema trânsito dentro da transversalidade.

O Rumo à Escola, que teve início em outubro de 2001, tinha em sua programação a produção de uma série de recursos pedagógicos de auxílio ao professor e ao aluno. 
Mantinha um Portal de trânsito para a intercomunicação e estudo entre os professores e equipes de trabalho - DENATRAN; realizou teleconferência sobre trânsito entre todos os quinze Estados; e programou a realização de vários cursos a distância para os professores.

Em relação à equipe de trabalho, realizava, a cada três meses, Encontros Técnicos de atualização, debate e avaliação do Projeto. Os Encontros ocorriam sempre em Brasília.

\subsection{Pesquisa sobre a visão do trânsito por parte dos alunos}

Para saber sobre a visão dos alunos a respeito do trânsito, foi solicitado a eles que respondessem à seguinte questão, podendo sua resposta ser uma imagem representativa:

Qual a primeira coisa que lhe vem à cabeça quando ouve a palavra trânsito?

Ao todo, responderam a esta pergunta 46.000 (quarenta e seis mil) alunos das 225 (duzentas e vinte e cinco) escolas integrantes do Projeto. A pesquisa envolveu alunos da $1^{\text {a }}$ a $8^{\text {a }}$ séries, correspondente hoje, ano de 2010 , do primeiro ao nono ano.

Para a apresentação dos resultados desse estudo, extraiu-se uma subamostra de 3.944 imagens representativas. A técnica estatística utilizada foi a da amostragem sistemática, sendo aproximadamente 260 respostas como representação de cada Estado.

Nesta subamostragem, levou-se em consideração um grau de confiabilidade de $95 \%$, com uma margem de erro de 1,5\% - para mais ou para menos - para os quinze Estados estudados. Para cada Estado individualmente, a margem de erro é de cerca de 5,8\%. Assim, ficou definida a distribuição da amostragem dos desenhos feitos pelos alunos, por Estado, a ser analisada, conforme descrita na tabela 4.3, abaixo. 
Tabela 4.3. Distribuição, por Estado selecionado, da amostra representativa da pesquisa junto aos alunos. Fonte: Projeto Rumo à Escola

\begin{tabular}{|c|c|c|c|}
\hline Estado (sigla) & Frequência & Percentual & Percentual Acumulado \\
\hline RN & 293 & 7,4 & 7,4 \\
\hline RS & 276 & 7,0 & 14,4 \\
\hline PB & 249 & 6,3 & 20,7 \\
\hline CE & 322 & 8,2 & 35,8 \\
\hline AL & 271 & 6,9 & 42,4 \\
\hline SP & 261 & 6,6 & 48,8 \\
\hline ES & 253 & 6,4 & 54,0 \\
\hline AP & 205 & 5,2 & 60,4 \\
\hline SC & 253 & 6,4 & 67,3 \\
\hline MS & 270 & 6,8 & 73,8 \\
\hline AM & 256 & 6,5 & 80,5 \\
\hline PR & 264 & 6,7 & 96,5 \\
\hline PA & 237 & 6,0 & 100,0 \\
\hline DF & 278 & 7,0 & \\
\hline PE & 256 & 6,5 & $\mathbf{1 0 0 , 0}$ \\
\hline TOTAL & $\mathbf{3 9 4 4}$ & & \\
\hline & &
\end{tabular}

No ato de aplicação da pesquisa, técnicos e professores foram orientados para não exercerem nenhum tipo de influência no processo de criação dos alunos, pois a ideia era exatamente a de que os alunos, por meio de uma imagem representativa, traduzissem a maneira que eles viam o trânsito.

Do conjunto dos alunos pesquisados, $63 \%$ pertenciam a escolas da rede pública e $37 \%$ a escolas da rede particular, mantendo-se a proporção real de participação das escolas públicas e particulares no Projeto Rumo à Escola. A amostra também restringiu a faixa etária dos alunos, considerando apenas as idades entre 6 e 15 anos.

Os gráficos apresentados abaixo mostram a visualização do perfil das escolas e dos alunos. 
Gráfico 4.1. Distribuição da amostra por tipo de escola

Distribuição por Tipo de Escola

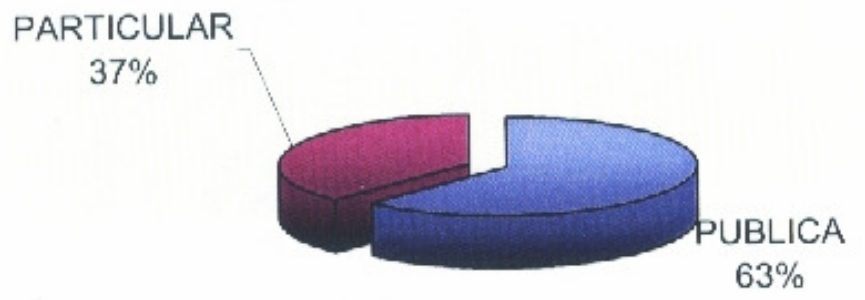

Gráfico 4.2. Distribuição da amostra por idade dos alunos

\section{Distribuição das Idades}

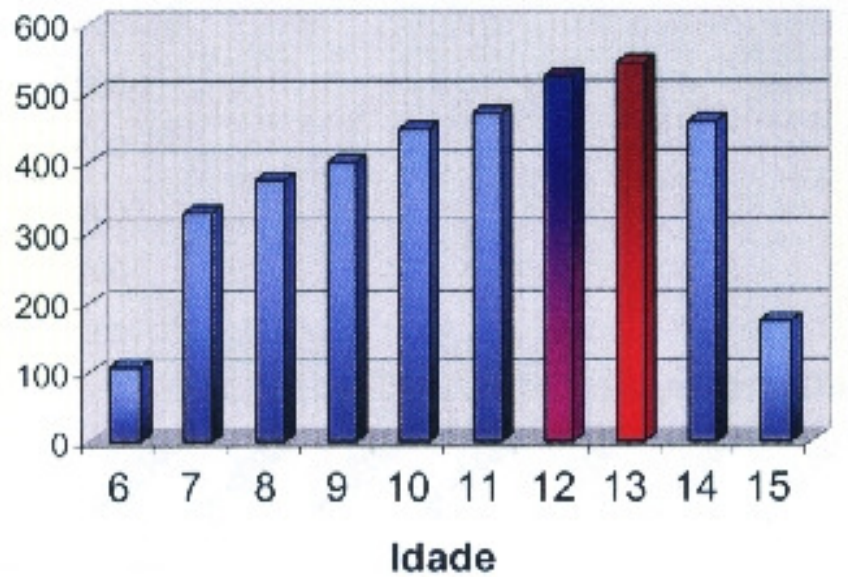

Gráfico 4.3. Distribuição da amostra por série dos alunos

\section{Distribuição por Série}

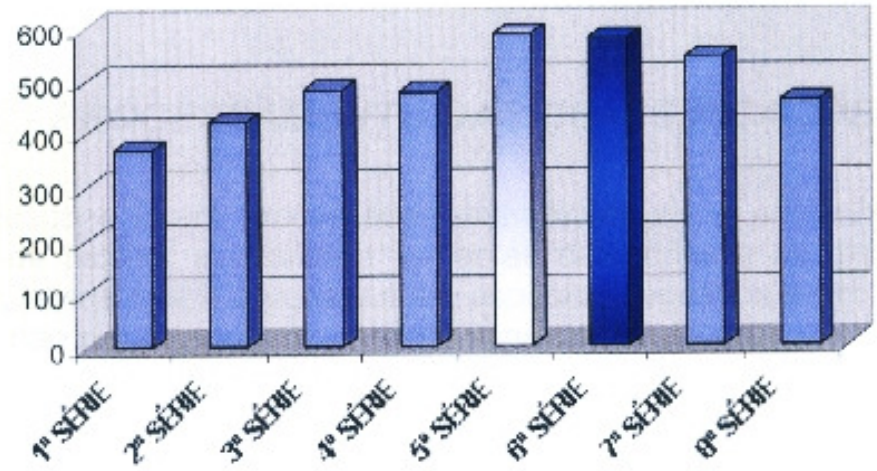


Foi estabelecida uma classificação para representar numericamente as imagens reproduzidas pelos alunos. Assim, os desenhos e as justificativas foram indicados conforme categorias a seguir:

1. Sinalização semafórica - para desenhos de semáforos

2. Infraestrutura viária mais veículo - para ruas, veículos, bicicletas, patins...

3. Faixa de segurança - desenho exclusivo da faixa

4. Sinalização - para vertical ou horizontal, excetuando as definidas acima

5. Trânsito não desejável - para aspectos negativos (acidente, poluição etc)

6. Pedestre - para desenho de pessoas

7. Congestionamento - para veículos enfileirados

8. Fiscalização - para a figura do guarda de trânsito

9. Trânsito desejável - aspectos positivos (respeito, cidadania, prazer, vida etc)

As justificativas (escritas) foram separadas da seguinte maneira:

1. Meios de locomoção

2. Legislação - quando se referiram a normas ou sinalização

3. Comportamentos - sobre desrespeito, paciência etc.

4. Acidentes - batidas, atropelamentos, velocidade etc.

5. Agentes externos - questões de estresse, barulho, poluição etc.

Os resultados obtidos com a pesquisa, considerando a classificação estabelecida pelo Projeto Rumo à Escola, descritas acima são apresentados nos gráficos 4.4, 4.5 e 4.6, abaixo.

Gráfico 4.4. Categoria dos desenhos

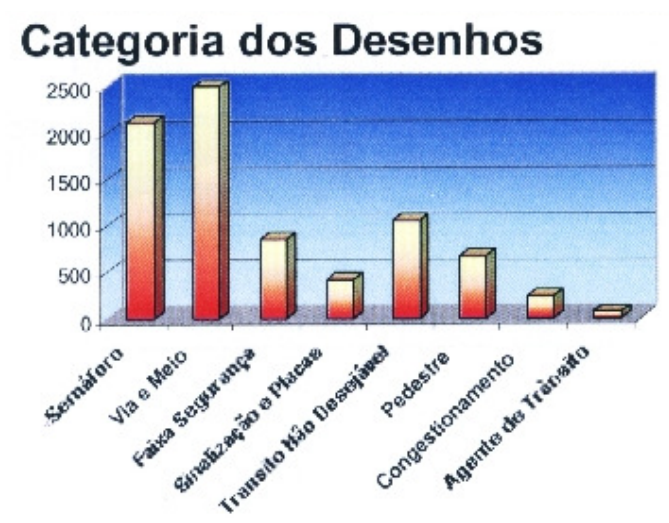


Gráfico 4.5. Categoria dos desenhos por tipo de escola

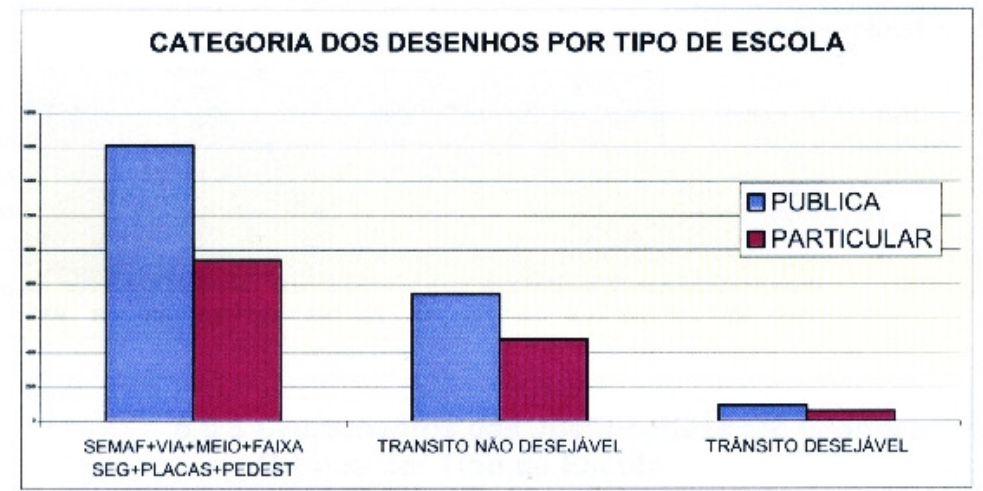

Gráfico 4.6. Agrupamento das categorias por Estado

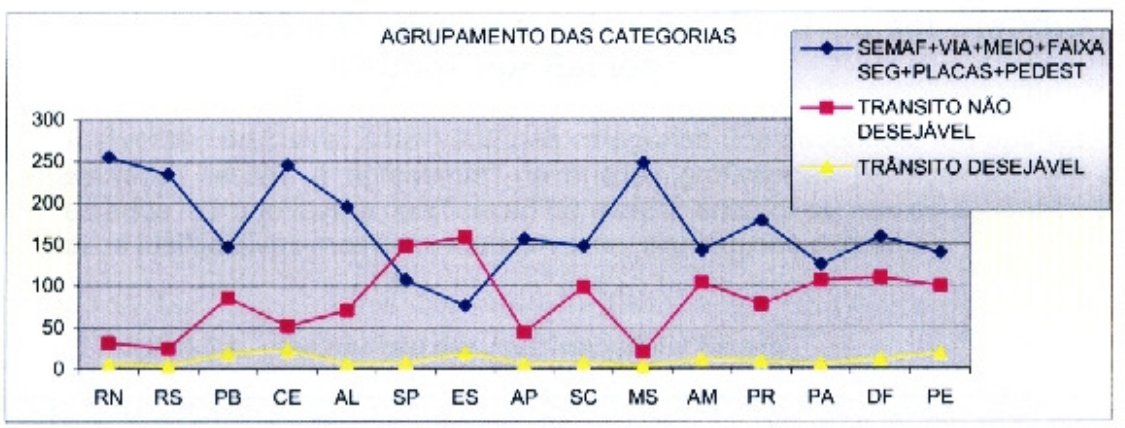




\subsection{A presença de elementos de Engenharia na percepção dos alunos}

$\mathrm{Na}$ verificação dos desenhos, vários apresentaram características que poderiam se enquadrar em mais de uma categoria pré-definida, entretanto, foi verificado aquela de maior intensidade ou que mais se destacava na representação do aluno. Outro importante fato a ser destacado é que alguns desenhos não permitiam uma boa interpretação do pensamento do aluno sobre o trânsito e só se tornaram compreensíveis a partir da leitura da justificativa transcrita abaixo do desenho.

Ao se fazer a verificação dos resultados individualizados por categoria, observa-se um elevado número de representações voltadas para o semáforo, a via e o meio de locomoção, a sinalização com placas e pedestres, que juntas somaram 82,9\% das imagens apresentadas nos desenhos. Este fato é um indicativo de que, quando se fala de trânsito, a visão dos alunos está próxima da visão imediata de sua realidade, traduzida nos elementos físicos colocados no sistema viário pela engenharia de tráfego. O trânsito fica restrito ao espaço do trinômio "homem", "veículo" e "via", vistos quase sempre de forma negativa ou como um mal necessário. Quando agrupados, a dimensão "acidente" também toma proporções de destaque, chegando a quase $60 \%$.

Outro relevante dado a ser discutido é o grau de alfabetização das crianças. Percebe-se na pesquisa uma grande dificuldade das crianças em expressarem suas justificativas por escrito, principalmente os alunos das escolas públicas. Talvez isto explique o fato de $16,9 \%$ dos desenhos da amostra não apresentarem a justificativa escrita.

Em raríssimos momentos, o trânsito foi representado com a imagem de convivência salutar, exercício da cidadania, ou mesmo, como meio de locomoção desvinculado de acidentes ou congestionamentos. Esta visão do aluno independe se a escola a que pertence é da rede pública ou particular.

Em resumo, a tendência de pensamento dos alunos ficou voltada para um trânsito violento e muitas vezes trágico, representado por acidentes e mortes, e diretamente vinculado aos elementos dispostos pela engenharia de tráfego. 
Uma das importantes contribuições que se pode traduzir desta pesquisa está nas informações de como os alunos veem o trânsito hoje e dos elementos que estes mais reconhecem, ditados como obras e marcações da engenharia. Com base em tais dados, pode-se melhor orientar propostas e projetos, da União, dos Estados, municípios ou da iniciativa privada em relação a como transversalizar o tema trânsito no ensino fundamental. Parte desta contribuição foi estabelecida e pode ser verificada nos dois documentos de referência publicados no Brasil: a Proposta Psicopedagógica, de autoria de Rozestraten (2004), e as Diretrizes Nacionais da Educação para o Trânsito, publicadas pelo Denatran (2009). 


\section{5 \\ A TRANSVERSALIDADE NA EDUCAÇÃO PARA O TRÂNSITO}

\subsection{Conceito de temas transversais ${ }^{5}$}

A transversalidade se fundamenta na crítica de uma concepção de conhecimento que toma a realidade como um conjunto de dados estáveis, sujeitos a um ato de conhecer isento e distanciado. Aponta a complexidade do real e a necessidade de se considerar a teia de relações entre os seus diferentes e contraditórios aspectos. A transversalidade diz respeito, principalmente, à dimensão da didática, à possibilidade de se estabelecer, na prática educativa, uma relação entre aprender na realidade e da realidade de conhecimentos teoricamente sistematizados (aprender sobre a realidade) e as questões da vida real (aprender na realidade e da realidade).

A transversalidade promove uma compreensão abrangente dos diferentes objetos de conhecimento, bem como a percepção da implicação do sujeito de conhecimento na sua produção, superando a dicotomia entre ambos. Por essa mesma via, a transversalidade abre espaço para a inclusão de saberes extraescolares, possibilitando a referência a sistemas de significado construídos na realidade dos alunos.

Para que um tema possa ser considerado transversal, deve atender aos requisitos básicos de: Ser de urgência social; De abrangência nacional; Apresentar possibilidade de ensino e aprendizagem no ensino fundamental; E deve favorecer a compreensão da realidade e a participação social.

Assim, os temas eleitos, em conjunto, devem possibilitar uma visão ampla e consistente da realidade brasileira e sua inserção no mundo, além de desenvolver um trabalho educativo que possibilite uma participação social dos alunos. O trânsito se enquadra perfeitamente nos critérios estabelecidos.

\footnotetext{
${ }^{5}$ Ministério da Educação. Parâmetros Curriculares Nacionais, vol. 8, 1997.
} 


\subsection{Realidade do ensino fundamental no Brasil}

O ensino fundamental, até o final de 1996, esteve estruturado nos termos previstos pela Lei Federal 5.692, de 11 de agosto de 1971. Essa lei, ao definir as diretrizes e bases da educação nacional, estabeleceu como objetivo geral, tanto para o ensino fundamental quanto para o ensino médio, proporcionar aos educandos a formação necessária ao desenvolvimento de suas potencialidades como elemento de autorrealização, preparação para o trabalho e para o exercício consciente da cidadania. Foi também estabelecido o núcleo comum obrigatório em âmbito nacional para o ensino fundamental e médio.

Em 1990, o Brasil participou da Conferência Mundial de Educação para Todos, em Jomtien, na Tailândia, convocada pela Unesco, Unicef, PNUD e Banco Mundial. Dessa conferência, assim como da Declaração de Nova Delhi - assinada pelos nove países em desenvolvimento de maior contingente populacional do mundo -, resultam posições consensuais na luta pela satisfação das necessidades básicas de aprendizagem para todos, capazes de tornar universal a educação fundamental e de ampliar as oportunidades de aprendizagem para crianças, jovens e adultos.

Assim sendo, e considerando o quadro da educação brasileira e os compromissos assumidos internacionalmente, o, então, Ministério da Educação e do Desporto atualmente, Ministério da Educação - coordenou a elaboração do Plano Decenal de Educação para Todos (1993-2003).

A Lei de Diretrizes e Bases da Educação Nacional - LDBEN reforça a necessidade de se propiciar a todos a formação básica comum, o que pressupõe a formulação de um conjunto de diretrizes capaz de nortear os currículos e seus conteúdos mínimos, incumbência que, nos termos do art. $9^{\circ}$, inciso IV, é remetida para a União. Para dar conta desse amplo objetivo, a LDBEN consolida a organização curricular de modo a conferir uma flexibilidade no trato dos componentes curriculares, reafirmando, desse modo, o princípio da base nacional comum (Parâmetros Curriculares Nacionais), a ser complementada por uma parte diversificada em cada sistema de ensino e escola na prática, repetindo o art. 210 da Constituição Federal. 
Em síntese, o currículo, tanto do ensino fundamental quanto do ensino médio, deve obrigatoriamente propiciar oportunidades para o estudo da língua portuguesa, da matemática, do mundo físico e natural e da realidade social e política, enfatizando-se o conhecimento do Brasil. Abrange ainda o ensino da Arte e da Educação Física e, quanto ao ensino religioso, a LDBEN estabelece como disciplina do horário normal das escolas públicas, porém com matrícula facultativa, respeitando as preferências manifestadas pelos alunos ou por seus responsáveis (art. 33). Fica também obrigatório o ensino de pelo menos uma língua estrangeira moderna, a partir da quinta série do ensino fundamental (art. 26, $\S 5^{\circ}$ ).

Atualmente, verifica-se que a organização curricular da educação escolar caminha no sentido de conferir ao aluno, dentro da estrutura federativa, efetivação dos objetivos da educação democrática.

O processo de elaboração dos Parâmetros Curriculares Nacionais começou com estudos, realizados pela Fundação Carlos Chagas, sobre as propostas curriculares de Estados e municípios brasileiros e de contato com informações relativas a experiências de outros países. Foram analisados subsídios oriundos do Plano Decenal de Educação, de pesquisas nacionais e internacionais, dados estatísticos sobre desempenho de sala de aula difundidos em encontros, seminários e publicações.

Assim, formulou-se uma proposta inicial que foi a discussão, em âmbito nacional, entre os anos de 1995 e 1996, contando com a participação de docentes de universidades públicas e particulares, técnicos de secretarias estaduais e municipais de educação, de instituições representativas de diferentes áreas de conhecimento, especialistas e educadores. Ao todo, foi efetivado cerca de setecentos pareceres que serviram de base para a reformulação da proposta. Outros encontros, regionalizados, foram realizados pelo MEC.

O Ensino Fundamental no Brasil compreende desde a $1^{\mathrm{a}}$ até a $8^{\mathrm{a}}$ ou $9^{\mathrm{a}}$ séries, ou seja, o tradicional primeiro grau completo.

Nos seus objetivos gerais, contidos nos Parâmetros Curriculares Nacionais, está contemplado o fato de os alunos apresentarem capacidade para: 
- Compreender a cidadania como participação social e política, bem como exercício de direitos e deveres políticos, civis e sociais, adotando, no dia a dia, atitudes de solidariedade, cooperação e repúdio às injustiças, respeitando o outro e exigindo para si o mesmo respeito;

- Posicionar-se de maneira crítica, responsável e construtiva nas diferentes situações sociais, utilizando o diálogo como forma de mediar conflitos e de tomar decisões coletivas;

- Conhecer características fundamentais do Brasil nas dimensões sociais, materiais e culturais como meio para construir progressivamente a noção de identidade nacional e pessoal e o sentimento de pertinência ao país;

- Conhecer e valorizar a pluralidade do patrimônio sociocultural brasileiro, como também aspectos socioculturais de outros povos e nações, posicionando-se contra qualquer discriminação baseada em diferenças culturais, de classe social, de crenças, de sexo, de etnia ou outras características individuais e sociais;

- Perceber-se integrante, dependente e agente transformador do ambiente, identificando seus elementos e as interações com eles, contribuindo ativamente para a melhoria do meio ambiente;

- Desenvolver o conhecimento ajustado de si mesmo e o sentimento de confiança em suas capacidades afetiva, física, cognitiva, ética, estética, de inter-relação pessoal e de inserção social, para agir com perseverança na busca de conhecimento e no exercício da cidadania;

- Conhecer e cuidar do próprio corpo, valorizando e adotando hábitos saudáveis como um dos aspectos básicos da qualidade de vida e agindo com responsabilidade em relação à sua saúde e à saúde coletiva;

- Utilizar as diferentes linguagens - verbal, matemática, gráfica, plástica e corporal - como meio para produzir, expressar e comunicar suas ideias, 
interpretar e usufruir das produções culturais, em contextos públicos e privados, atendendo a diferentes intenções e situações de comunicação;

- Saber utilizar diferentes fontes de informação e recursos tecnológicos para adquirir e construir conhecimentos;

- Questionar a realidade formulando-se problemas e tratando de resolvê-los, utilizando para isso o pensamento lógico, a criatividade, a intuição, a capacidade de análise crítica, selecionando procedimentos e verificando sua adequação.

Durante as décadas de 70 e 80 , a tônica da política educacional brasileira recaiu sobre a expansão das oportunidades de escolarização, havendo um aumento expressivo no acesso à escola básica. Entretanto, era grande o índice de repetência e de evasão.

Nas estatísticas do Ministério da Educação, a oferta de vagas está praticamente universalizada no país, sendo que o maior contingente de crianças fora da escola encontra-se na região Nordeste e as regiões Sul e Sudeste apresentam desequilíbrios na localização das escolas. No caso das grandes cidades, insuficiência de vagas, provoca a existência de um número excessivo de turnos e a criação de escolas unidocentes ou multisseriadas.

Na década de 90, mais precisamente, 1994, os 31,2 milhões de alunos do ensino fundamental concentravam-se predominantemente nas regiões Sudeste (39\%) e Nordeste (31\%), seguidas das regiões Sul (14\%), Norte (9\%) e Centro-Oeste (7\%).

A pesquisa do Ministério da Educação demonstrou ainda que a maioria absoluta dos alunos frequentava escolas públicas $(88,4 \%)$ localizadas em áreas urbanas $(82,5 \%)$, como resultado do processo de urbanização do país nas últimas décadas, e da crescente participação do setor público na oferta de matrículas. O setor privado respondia, então, por apenas $11,6 \%$ da oferta, em consequência de sua participação declinante desde o início dos anos 70.

Quanto ao número de estabelecimentos de ensino, ao todo eram, na época da pesquisa, 194.487, sendo mais de $70 \%$ das escolas rurais, apesar de responderem por apenas 
17,5\% da demanda de ensino fundamental. Estas escolas rurais concentravam-se, principalmente, na região Nordeste $(50 \%)$.

A situação mostrou-se grave ao se observar a evolução da distribuição da população por nível de escolaridade. Apesar de ter ocorrido considerável avanço na escolaridade de primeira a quarta séries (primeira fase do ensino fundamental), em relação aos demais níveis de ensino, a escolaridade era muito insuficiente. Em 1990, apenas 19\% da população do país tinham o primeiro grau completo; $13 \%$ o nível médio; e $8 \%$ o nível superior.

Considerando a importância do ensino fundamental e médio para assegurar a formação de cidadãos aptos a participar democraticamente da vida social, a situação apresentada indica a urgência de um esforço que o Estado e a Sociedade Civil deverão assumir para superar o quadro existente.

Durante a década de 90, verificou-se melhoria das taxas de repetência e evasão do ensino fundamental, que atingiam, respectivamente, 33\% e 5\% em 1992. Essa tendência positiva deve ser considerada, uma vez que os estudos também revelam que a repetência constitui um dos problemas do quadro educacional do país, sendo que os alunos passavam, em média, 5 anos na escola antes de se evadirem ou levavam cerca de 11,2 anos para concluir as oito séries de escolaridade obrigatória. Entretanto, infelizmente, a pesquisa também apontava que parte significativa da população estudantil acabava desistindo da escola, desestimulada em razão das altas taxas de repetência e pressionada por fatores socioeconômicos que obrigam boa parte dos alunos ao trabalho precoce.

Face a essa situação, alguns Estados e municípios começaram a implementar programas de aceleração do fluxo escolar, com o objetivo de promover, a médio prazo, a melhoria dos indicadores de rendimento escolar. São iniciativas consideradas extremamente importantes pelo Ministério da Educação, já que pesquisa realizada em 1995, por meio do Sistema Nacional de Avaliação da Educação Básica (SAEB), mostrou que quanto maior a distorção idade/série, pior o rendimento dos alunos em língua portuguesa e matemática, tanto no ensino fundamental como no médio. 
As dificuldades e problemas com o desempenho dos alunos remetem-nos, também, diretamente à necessidade de se considerarem aspectos relativos à formação do professor. De acordo com o Censo Educacional, realizado na década de 90, cerca de 1,3 milhão, ou seja, $86,3 \%$ dos professores encontram-se na rede pública, sendo que mais de $79 \%$ relacionam-se às escolas da área urbana e apenas 20,4\% à zona rural.

No ano de 2003, durante execução do Projeto Rumo à Escola - parceria UNESCO e Denatran - ao visitar escolas de Ensino Fundamental, foi possível observar os problemas e as diferenças existentes nas diversas realidades entre a rede pública e a rede privada.

No que concerne à estrutura física (local da escola, número e condições das salas de aula, sala para professores, biblioteca, pátio de recreação, secretaria de atendimento aos alunos e ao público, espaço para coordenação pedagógica, sala de vídeo etc), sem sombra de dúvidas, as escolas particulares estão muito mais bem servidas em relação às escolas públicas, salvo raras exceções. Estas observações não querem dizer que a escola pública seja ruim em espaço, mas sim que, numa parcela significativa, estão inadequadas para o número de alunos que atendem e para o desempenho de seu papel institucional.

A situação física, contudo, não foi motivo para as escolas deixarem de trabalhar com as diferentes temáticas na transversalidade. O grande problema, efetivamente, passa pelas condições de recursos pedagógicos disponíveis nas escolas, principalmente nas escolas públicas. Normalmente, as escolas públicas contam com uma sala - pequena ou média para a apresentação de audiovisual e um aparelho de TV pequeno acoplado a um vídeo; um pequeno espaço destinado a laboratório de informática com pouco mais de 10 computadores, quase sempre com baixo índice de manutenção e atualização de software; três ou quatro retroprojetores de uso comum aos professores; uma ou duas unidades de aparelho de som etc. Os recursos disponíveis são insuficientes para se trabalhar o número de alunos normalmente matriculados e os poucos que existem deixam a desejar em termos de tecnologia.

As escolas particulares, em sua maioria, sofrem menos deste problema relacionado aos recursos pedagógicos. Geralmente têm quantitativos maiores e melhores, permitindo que os professores possam trabalhar os alunos em número menor e em diferentes 
momentos do processo de aprendizagem. Destaca-se também que, no caso destas escolas, os recursos pedagógicos disponíveis para os alunos utilizarem são muito maiores que os das escolas públicas. Soma-se a esta situação generalizada de infraestrutura das escolas o problema do desestímulo de parte dos professores, seja por questões salariais, falta de tempo ou outro.

Este breve levantamento de algumas realidades do nosso ensino fundamental é importante para se refletir sobre a capacidade da atual estrutura - física e recursos humanos - absorver, introduzir e difundir com êxito os temas transversais, dentre eles o trânsito, para os milhões de alunos espalhados pelo país, considerando as proposituras estabelecidas nos Parâmetros Curriculares Nacionais do ensino fundamental, a amplitude de seus objetivos e o papel que desempenha na formação de valores e atitudes voltados para o comportamento do indivíduo na sociedade.

É neste cenário, aparentemente complexo, que se propõe inserir conteúdos programáticos transversais abordando o tema trânsito dentro do ensino fundamental. Destaca-se, contudo, que, em nenhum momento, as pesquisas apresentaram dificuldades com a quantidade de conteúdos ou temáticas solicitadas aos estabelecimentos de ensino.

\subsection{O porquê do ensino de trânsito como tema transversal e não disciplina}

Sempre que se fala em educar para o trânsito, surge a dúvida e o questionamento sobre a forma de se implementar este ensino. A questão, normalmente, é focada entre ter disciplina específica na matriz curricular ou trabalhar o assunto como tema transversal.

O fato é que, considerando o retrospecto da prática pedagógica do Ensino Fundamental no Brasil e, especialmente, a legislação educacional brasileira, percebe-se que a viabilidade de se efetivar a educação de trânsito passa necessariamente pela escolha deste como um tema transversal. Alguns aspectos a serem levados em conta:

A Lei de Diretrizes e Bases da Educação Nacional (LDBEN), datada de 1996, define a matriz curricular básica do ensino fundamental, não sendo incluído as diferentes 
temáticas sociais, como violência, drogas, sexualidade, meio ambiente, trânsito, etc., como disciplinas específicas, podendo tais temas serem tratados diretamente pelas escolas como conteúdos programáticos transversais, dentro dos critérios estabelecidos pelos Parâmetros Curriculares Nacionais (PCN).

O Conselho Nacional de Educação emitiu o Parecer N. 22/2004, encaminhado ao Ministério das Cidades, em que afirma categoricamente que não cabe se falar em disciplina de trânsito para se trabalhar na rede escolar brasileira. “(...) fica absolutamente definido que não convém a inclusão compulsória de disciplinas, a partir de decisão normativa federal, nos currículos das escolas de Educação Básica. Dessa forma, não há por que se falar de inclusão de disciplina Educação para o Trânsito".

A Lei 9.503/97, que instituiu o Código de Trânsito Brasileiro, cita, em seu artigo 76, a obrigatoriedade de se trabalhar a educação para o trânsito em toda a rede escolar mediante proposta de conteúdo programático sobre segurança no trânsito. Portanto, também não suscita a presença de disciplina específica.

Dentro da prática pedagógica, há que se observar o caráter multidisciplinar do tema trânsito - envolvendo diferentes áreas do conhecimento, como direito, engenharia, psicologia, educação, sociologia,... -, o que também inviabilizaria o trabalho se o mesmo for feito sob a forma de uma disciplina.

Também há que se considerar a experiência da escola brasileira em trabalhar temáticas de importância social, como a violência e a droga, sob a abordagem de temas transversais. Este fato facilita a inclusão do trabalho com o tema trânsito, tendo em vista que não se altera a prática pedagógica.

FILHO (2004) afirma que: “... a oportunidade de interferir nos rumos da educação de trânsito não prescinde de eixos norteadores. No âmbito escolar, considerando o que preconiza o artigo 76 do Código de Trânsito Brasileiro, os preceitos existentes na proposta dos temas transversais fornecem valiosas pistas quanto à orientação, possibilidades e métodos de trabalho. ... Estes demonstram afiada sintonia com uma idéia de uma educação de trânsito transformadora." 
Ainda, segundo FILHO (2004), no Canadá, os representantes da instituição equivalente ao Ministério da Educação aqui no Brasil argumentam que, além dos grupos que advogam a importância da temática trânsito, setores ligados à questão ambiental, à educação sexual, entre outros, também reivindicam seu lugar ao sol. E, perante a contraargumentação de que o tempo dos alunos é um "bem escasso", o lobby da educação de trânsito não se deu por vencido. A saída proposta naquela discussão segue também a tendência adotada no caso brasileiro: o recurso à transversalidade.

\subsection{Posicionamento de professores sobre a transversalização do tema trânsito}

De modo geral, parcela significativa dos professores está habituada à prática da transversalização de temáticas sociais em sala de aula. É o caso de atividades desenvolvidas em relação ao lixo, ao uso de drogas, violência etc.

Entretanto, há uma dificuldade de entendimento dos professores quando se trata do tema trânsito. Trata-se da dificuldade de visualizar o trânsito fora do tradicional conceito (homem - veículo - via) e verificar que o princípio do verbo transitar é locomover-se e, através desta locomoção, você ser capaz de estabelecer um convívio social com outros, utilizando-se da linguagem da comunicação - seja ela visual (através da sinalização), escrita, falada, por gestos etc.

Os professores se manifestam a favor da transversalização do tema trânsito na escola e reconhece sua importância e extrema necessidade. O que os preocupa e os deixa inquietos é pensar que a ideia de transversalizar possa estar desarticulada de uma estrutura do poder público para gerar orientação básica / capacitação dos professores, sem a produção e encaminhamento contínuo de materiais didáticos adequados à pedagogia das escolas, sem a base de apoio local que permita o contato direto dos professores com o sistema de trânsito ou, pior ainda, sem que a escola - como instituição que tem por princípio fomentar a descoberta, a discussão e o desenvolvimento das habilidades dos alunos - participe efetivamente da construção deste processo de ensino e educação para o trânsito. Enfim, os professores demonstram 
o receio de que o tema trânsito seja ou se transforme apenas no repasse de informações técnicas e decorativas sobre as leis, as placas, o sistema viário etc.

É preciso relembrar a teoria da psicologia da aprendizagem, que nos apresenta a educação como um processo, e como tal, tem características globais e contínuas. Assim, não se pode esperar que os professores superem, da noite para o dia, conceitos e concepções a respeito do trânsito que ainda não foram superados pelos dirigentes do sistema após cinco décadas da cultura do automóvel. Há que se fazer um trabalho mais consistente e regado de acompanhamento e auxílio constante junto às escolas. É o que expressam e espera os professores entrevistados durante o trabalho com o Projeto Rumo à Escola.

\subsection{Posturas sinalizadas por instituições públicas e privadas no Brasil}

Em relação aos dirigentes de trânsito, discutindo o tema transversalização, o que se percebe é um grande desconhecimento das questões relacionadas ao processo ensinoaprendizagem e, em alguns casos, desconhecimento também das questões associadas ao próprio trânsito.

O maior exemplo nos é dado com a total descontinuidade apresentada nos projetos de educação dos organismos públicos de trânsito. Esta quebra na continuidade que também ocorre na própria gestão destes órgãos, que, por se tratarem de cargo de confiança, estão em constante alteração. Apesar disto, diferentes projetos e ações foram desenvolvidas pelo Governo Federal nos últimos dez anos, sendo algumas destas apresentadas no anexo desta tese.

O Departamento Nacional de Trânsito - DENATRAN exibe postura favorável ao processo de transversalização do tema trânsito nas escolas, conforme preconizado pelo Código de Trânsito Brasileiro, em seu artigo 76. A instituição também sofreu com alguns processos de descontinuidade, a exemplo do ocorrido com o Projeto Rumo à Escola, que, aos poucos, foi sendo desarticulado, interrompendo-se no ano de 2003. Seis anos depois, no ano de 2009, o Denatran publica na Portaria 147/2009 as Diretrizes 
Nacionais para o trabalho de educação para o trânsito na Educação Infantil e no Ensino Fundamental.

Nos Estados, são raros os Departamentos Estaduais de Trânsito - DETRAN que desenvolvem trabalhos contínuos de educação de trânsito junto às escolas, principalmente considerando a ideia da transversalidade. Muitos ficam limitados pela questão financeira, não pela falta do recurso, mas pelo fato de o mesmo estar alocado em outros órgãos do Estado, normalmente na Secretaria de Governo ou setor onde o DETRAN está vinculado.

De outro lado, a iniciativa privada tem dado um pouco de sua contribuição. Algumas se destacam pela criação e execução de Programas específicos voltados para a educação e a segurança no trânsito. Pode-se citar, como exemplo, a FIAT automóveis - que desenvolveu dois programas de educação de trânsito direcionados para escolas, o "Moto Perpétuo" (parceria entre a FIAT e o Ministério da Educação) e o "FIAT Apita" (encaminhado em parceria com o DENATRAN) - e a empresa Volvo do Brasil - que, há dezoito anos, desenvolve o "Programa Volvo de Segurança no Trânsito" e, em 2009, patrocinou o lançamento do livro "20 Anos de Lições de Trânsito: desafios e conquistas do trânsito brasileiro de 1987 a 2007”, de autoria de J. Pedro Correa (CORRÊA, 2009).

Os dirigentes destas instituições demonstram-se favoráveis ao ensino de trânsito nas escolas e sob a ótica da transversalidade. Diversas outras empresas e instituições de caráter privado têm dado sua contribuição ao processo de educar para o trânsito.

\subsection{Considerações finais}

Com base nos estudos teóricos e nos resultados da pesquisa de campo mostrados neste capítulo, chega-se a conclusão que a forma mais adequada de trabalhar o tema trânsito no Ensino Fundamental no Brasil é, indiscutivelmente, introduzir o assunto como tema transversal.

O conceito básico de transversalidade está definido no aspecto legal através da Lei de Diretrizes e Bases da Educação Nacional (LDBEN) e nos Parâmetros Curriculares Nacionais (PCN), reforçados na nossa legislação maior do trânsito, no artigo 76, por 
meio da Lei federal de N. 9.503/97 - que instituiu o Código de Trânsito Brasileiro (CTB).

É preciso também considerar que a transversalidade de temas de urgência social e abrangência nacional já é prática na realidade das escolas do Ensino Fundamental, e, quando se trata do tema trânsito, percebe-se a possibilidade de apoio técnico e parceria de órgãos públicos e instituições privadas. 


\section{6 \\ O CONTEÚDO PROGRAMÁTICO NA EDUCAÇÃO PARA O TRÂNSITO}

\subsection{A proposta psicopedagógica de Rozestraten}

Segundo ROZESTRATEN (2004), nas séries iniciais do Ensino Fundamental traduzidas da $1^{\mathrm{a}}$ a $8^{\mathrm{a}}$-, abordam-se conceitos sobre o corpo e suas partes, o espaço e medidas básicas, a direcionalidade, lateralidade e equilíbrio, tempo, movimento e velocidade, o trânsito relacionado a seus elementos essenciais e o conhecimento elementar da cidade, além da questão dos dados numéricos do trânsito, das ações e reações, dos meios de transportes (com destaque para a bicicleta), da comunicação, da educação e segurança, da própria história do automóvel, das normas e regras (mais especificamente o próprio Código de Trânsito), o Sistema Nacional de Trânsito, e a relação infrações e crimes.

Assim, na proposta de Rozestraten, a educação para o trânsito no ensino fundamental apresenta-se distribuída por séries e sob a forma da transversalidade, definindo assuntos a serem discutidos em cada disciplina, conforme segue.

\section{Primeira série}

\section{Português}

Conceitos corporais, palavras escritas; Conceitos espaciais e palavras escritas; Conceitos de trânsito e palavras escritas; e conheça a sua cidade.

$\underline{\text { Matemática }}$ 
Conceito de espaço e localização espacial; Conceito de tamanho e distância; Conceito de movimento, velocidade e parada; Conjuntos no trânsito; e comportamento do pedestre.

Estudos Sociais

Estudos sociais; Comportamento certo do pedestre; Instrumentos e pessoas que facilitam a travessia; e comportamento do passageiro.

\section{Ciências e Saúde}

Conceitos corporais, imagem corporal; Funções das partes do corpo; Direcionalidade e lateralidade; Corpo e equilíbrio; Orientação auditiva; Diferenciação de sons; e ciência e saúde.

\section{Educação Artística}

Conceito de forma; Conceito e uso de cores; Conceito de planta e mapa mental da sala; Conceito de planta e mapa mental da escola; Conceito de vizinhança (arredores), mapa do quarteirão com as ruas vizinhas; Conceito de cidade e de bairros; O que é necessário para ter trânsito?; Conceito de via: rua, avenida, estrada e direção; Conceito e diferenciação de veículos; e as diversas pessoas no trânsito.

\section{Educação Física}

Distância de parada; O jogo de luta pelas bandeiras; e o pedestre educado.

\section{Segunda série}

\section{Português}

Escola e trânsito; Espaço em volta da escola e trânsito; Travessia; As pessoas que participam do trânsito; e conhecer sua cidade. 


\section{$\underline{\text { Matemática }}$}

Os números no trânsito; Transporte urbano; Os semáforos; Pessoas no trânsito; Pagamentos no trânsito; e conheça sua cidade.

\section{$\underline{\text { Estudos Sociais }}$}

O trânsito como um bem social; Observação da função social do trânsito; A escola e os arredores; A imagem da escola; Os arredores e a comunidade; O trânsito e os arredores; e o endereço.

\section{Ciências e Saúde}

A ciência; e ciência e o trânsito.

\section{Educação Artística}

Mapa mental da classe, da escola e dos arredores; Faixa de segurança e faixa de pedestres; Placas de sinalização; Semáforos; Placas de regulamentação; e fazer os veículos.

\section{Educação Física}

Travessia de pedestre; A distância de parada; Aproveitamento de algumas placas de regulamentação; e exercício de observação e reação rápida.

\section{Terceira série}

\section{Português}

Meios de transporte; Tipos de transporte conforme as distâncias e modalidades; Os sinais de regulamentação; Atividades do guarda ou policial de trânsito; Conheça sua cidade. 


\section{$\underline{\text { Matemática }}$}

A importância dos números no trânsito; Horários no trânsito; Desenhar e medir; Estatística de trânsito; Mapa mental da cidade.

\section{$\underline{\text { Estudos Sociais }}$}

Importância do trânsito; o transporte coletivo; As regras do transporte particular; O pedestre.

\section{Ciências e Saúde}

Trânsito e saúde; Cuidado com os pés; Ciência e trânsito; Evitar os lugares perigosos e as ações perigosas; Conversa com os acidentados.

\section{Educação Artística}

Desenhos de meios de transportes; Travessias; Criança no transporte coletivo; Maquete com diversos tipos de travessias; Fazer semáforos para pedestres e para veículos; Construir carros, caminhões e ônibus; Cantos de trânsito.

\section{Educação Física}

Trânsito caótico; Travessia de pedestres na faixa de segurança; Travessia com semáforo de pedestres e para veículos; Travessia somente com semáforo para os veículos; Travessia com ajuda do guarda de trânsito; A distância de parada e seus perigos.

\section{Quarta série}

\section{Português}

A bicicleta e seu uso; As normas de trânsito para o ciclista; Preparação de cartazes sobre as normas do ciclista; Conheça sua cidade. 


\section{Matemática}

A distância, suas medidas e conversão de uma unidade de medida em outra; O tempo e suas medidas; A velocidade no trânsito; A distância de parada; Placas que indicam medidas de distância, velocidade, peso e dimensões.

\section{Estudos Sociais}

As vias e os meios de transporte; Os sinais: a linguagem do trânsito; Os sinais de trânsito nas placas; Atividades de agente, guarda ou policial de trânsito; Conhecer sua cidade.

\section{Ciências e Saúde}

A ciência e as ciências; As ciências e o trânsito; A bicicleta e a saúde;.

\section{Educação Artística}

Os meios de transporte; Os meios especiais de transporte e de serviços; A sinalização; As placas de regulamentação; As placas de advertência; As linhas demarcatórias.

\section{Educação Física}

Montar, descer e equilíbrio; Capacidade de andar em círculo; Andar em linha curvada e evitar obstáculos; Passeio e competição ciclística; Desmontar, montar e consertar a bicicleta; Os principais comportamentos seguros do ciclista; Uma bicicleta é um veículo e deve seguir as regras de circulação de sua área; Dirigir defensivamente na bicicleta.

\section{Quinta série}

\section{Português}

A comunicação; O Código de Trânsito Brasileiro; Educação para o trânsito e segurança; Segurança; O trânsito e seus elementos. 


\section{$\underline{\text { Matemática }}$}

O novo Código de Trânsito Brasileiro, trânsito e seus elementos; Os meios de segurança para os pedestres; As proibições para os pedestres; Os ciclistas, suas regras e infrações.

\section{$\underline{\text { História e Geografia }}$}

História do automóvel no Brasil: O automóvel chega no Brasil..., O uso do automóvel se espalha no Brasil..., Parada das importações e consequências..., Explosão e Guerra..., Indústrias automobilísticas brasileiras (FMN), A Nacionalização..., Os primeiros salões de automóvel.

\section{Ciências e Saúde}

Ciência, natureza e cultura; Como funciona a Ciência; A natureza, ciência e cultura no trânsito; O pedestre no trânsito; A saúde e o trânsito.

\section{Educação Religiosa}

Religião e trânsito; Vida e segurança; Inteligência do homem e o transporte; Religião e leis humanas; O que a religião nos pede para fazer no trânsito.

\section{Educação Física e Inglês}

Palavras e expressões de trânsito em inglês; A violência no trânsito para os pedestres; As causas da violência.

\section{Sexta série}

\section{Português}

O que é o Código de Trânsito Brasileiro; A organização do CTB e sua utilidade; Quais os capítulos do CTB que tratam da circulação do ciclista e de outros condutores de 
veículos e do pedestre; A ultrapassagem; Iluminação, comunicação e controle de velocidade.

Matemática

As normas para os comportamentos dos pedestres; As normas para os comportamentos dos ciclistas; A classificação dos veículos.

\section{$\underline{\text { História e Geografia }}$}

Os trilhos iniciais: Os caminhos dos bandeirantes...; O sonho do outro e das pedras preciosas..., O ciclo do café e seus caminhos...; a construção das "estradas normais"...; Automóvel Clube e DNER; as grandes rodovias...; as categorias de rodovias e seus indicadores....

\section{Ciências e Saúde}

O que é um acidente de trânsito, a variedade; As condições diversas e as possibilidades de um acidente de trânsito; $\mathrm{O}$ acidente e os ferimentos.

\section{Educação Religiosa}

Deus e suas leis; Os dez mandamentos e o trânsito; O comportamento no trânsito.

\section{Educação Física e Inglês}

Palavras e expressões de trânsito em inglês; A violência no trânsito; A violência do e para o motorista; Jogos.

\section{Sétima série}

\section{Português}


O CTB e sua organização: capítulos; Artigos, parágrafos e incisos. Como se faz uma lei; Resoluções do Contran e anexos do CTB; As disposições preliminares; O Sistema Nacional de Trânsito (SNT); Como se tornar um excelente motorista.

\section{Matemática}

O que é um acidente de trânsito; Por que acontecem os acidentes de trânsito; As fases psicológicas que produzem comportamento.

\section{$\underline{\text { História e Geografia }}$}

Breve histórico do trânsito no mundo: Os primeiros veículos do mundo..., A Era do Ferro e as Cidades..., A Era Cristã e os Romanos..., A Idade Média e a Renascença..., O Século XIX - O inventor do automóvel..., A Construção de Carros na Europa..., A História do automóvel nos E.U.A.

\section{$\underline{\text { Ciências }}$}

As partes do automóvel: motor e o combustível, a transmissão, as rodas e os freios, a parte de refrigeração, a parte elétrica, a parte de carroçaria, a parte de informação, a parte da direção, a parte da suspensão, a parte de comunicação, a parte de segurança, a parte de socorros.

\section{Educação Religiosa}

Deus e o Código de Trânsito Brasileiro; O Sistema Nacional de Trânsito; Os veículos; A habilitação; As virtudes morais no trânsito.

\section{Educação Física e Inglês}

Palavras e expressões de trânsito em inglês; A violência do acidente de trânsito; Os crimes de trânsito no CTB; Os crimes de trânsito que não estão no CTB; Dicas de segurança contra assalto de carro; Jogos de Educação Física. 


\section{Oitava série}

\section{Português}

O Sistema Nacional de Trânsito e suas atribuições; A composição do Sistema Nacional de Trânsito - SNT; A competência dos órgãos de trânsito; Dos veículos, seu registro e licenciamento; RENAVAM; A habilitação dos condutores.

\section{$\underline{\text { Matemática }}$}

A municipalização no trânsito.

\section{$\underline{\text { História e Geografia }}$}

De onde vêm estas palavras...; De onde vêm os caminhos...; As estradas na América do Sul.

\section{Ciências}

O meio ambiente; $\mathrm{O}$ ambiente natural e o ambiente construído; A Psicologia e o ambiente; $\mathrm{O}$ motorista e o ambiente material do trânsito; $\mathrm{O}$ ambiente sonoro e visual: poluição; A ecologia e a humanidade.

\section{Educação Religiosa}

O registro; O licenciamento; A habilitação; As infrações; As virtudes morais no trânsito.

\section{Educação Física e Inglês}

Palavras e expressões de trânsito em inglês; Os crimes de trânsito; Jogos de Educação Física.

\subsection{As Diretrizes Nacionais do Denatran}


No ano de 2009, com base nos estudos da Câmara Temática de Educação e Cidadania no Trânsito - Câmara de assessoramento ao Conselho Nacional de Trânsito (Contran) -, o Departamento Nacional de Trânsito (Denatran) publicou a Portaria de No. 147/09, estabelecendo as Diretrizes Nacionais e os Referenciais Curriculares para a educação de trânsito na pré-escola e no ensino fundamental.

Segue o teor do documento:

Compreendendo que as bases legais para se trabalhar a educação para o trânsito encontram-se amparadas no inciso XII do artigo 23 da Constituição da República Federativa do Brasil; no inciso XVI do artigo 19, o caput do artigo 74 e os incisos I e II do Parágrafo Único do artigo 76 do Código de Trânsito Brasileiro; no artigo 26 da Lei n. 9.394, de 20 de dezembro de 1996, Lei de Diretrizes e Bases da Educação Nacional (LDBEN); no capítulo sobre temas locais contido nos Parâmetros Curriculares Nacionais: apresentação dos temas transversais, ética (v. 8); no Parecer n. 22/2004 do Conselho Nacional de Educação, homologado em 03 de fevereiro de 2005 e publicado no Diário Oficial da União em 04 de fevereiro de 2005, acreditamos que a Educação para o Trânsito no Ensino Fundamental deve fundamentar-se:

I - nas bases legais que orientam os Sistemas de Ensino da Educação Brasileira; e no Sistema Nacional de Trânsito;

II - na dimensão conceitual de trânsito como direito e que compreende aspectos voltados à segurança, à mobilidade humana, à qualidade de vida e ao universo das relações sociais no espaço público;

III - no reconhecimento do Trânsito como tema de urgência social, de abrangência nacional, que apresenta possibilidade de ensino e aprendizagem e que favorece a compreensão da realidade e a participação social; 
IV - no conjunto de valores que regulam nosso sistema de convivência e que envolvem o pensar e o agir de cada pessoa, respeitando sua liberdade;

V - nas fases de desenvolvimento do(a) aluno(a) e nas características específicas de cada etapa de ensino.

VI - nas diversidades culturais, nos diferentes espaços geográficos e nas relações que neles ocorrem, nas características regionais e locais da sociedade, da economia e da clientela.

Incluir o trânsito como tema transversal no currículo escolar deve ter como objetivos:

I - priorizar a educação a partir de exemplos positivos que reflitam o exercício da ética e da cidadania no espaço público;

II - desenvolver posturas e atitudes para a construção de um espaço público democrático e equitativo, por meio do trabalho sistemático e contínuo, durante toda a escolaridade, favorecendo o aprofundamento de questões relacionadas ao tema Trânsito;

III - superar o enfoque reducionista de que ações educativas voltadas ao tema Trânsito sejam apenas para preparar o futuro condutor;

IV - envolver a família e a comunidade nas ações educativas de trânsito desenvolvidas;

VI - contribuir para mudança do quadro de violência no trânsito brasileiro que hoje se apresenta; 
VII - criar condições que favoreçam a observação e a exploração da cidade, a fim de que os(as) alunos(as) percebam-se como agentes transformadores do espaço onde vivem.

A inclusão do tema Trânsito no currículo das instituições de Ensino Fundamental deve ser organizada de forma a possibilitar ao (à) aluno (a):

I - conhecer a cidade onde vive, tendo oportunidade de observá-la e de vivenciá-la;

II - conhecer seus direitos e cumprir seus deveres ao ocupar diferentes posições no trânsito: pedestre, passageiro, ciclista;

III - pensar e agir em favor do bem comum no espaço público;

IV - manifestar opiniões, ideias, sentimentos e emoções a partir de experiências pessoais no trânsito;

V - analisar fatos relacionados ao trânsito, considerando preceitos da legislação vigente e segundo seu próprio juízo de valor;

VI - identificar as diferentes formas de deslocamento humano, desconstruindo a cultura da supervalorização do automóvel;

VII - compreender o trânsito como variável que intervém em questões ambientais e na qualidade de vida de todas as pessoas, em todos os lugares;

VIII - reconhecer a importância da prevenção e do autocuidado no trânsito para a preservação da vida; 
IX - adotar, no dia a dia, atitudes de respeito às normas de trânsito e às pessoas, buscando sua plena integração ao espaço público;

X - conhecer diferentes linguagens (textual, visual, matemática, artística, etc.) relacionadas ao trânsito;

XI - criar soluções de compromisso para intervir na realidade.

Devem ser considerados procedimentos para a inclusão do Trânsito como tema transversal nas instituições de Ensino Fundamental:

I - o planejamento de atividades que promovam a análise, o debate e a reflexão sobre diferentes situações relacionadas ao transitar humano;

II - o uso do ambiente real de circulação (a cidade) como principal recurso educativo para o exercício da cidadania no trânsito;

III - a produção e a socialização de conhecimentos relacionados ao tema a partir do incentivo à pesquisa, à leitura e à escrita, à criatividade, à troca de ideias e de experiências;

IV - a promoção do envolvimento da família e da comunidade em atividades voltadas ao tema;

V - a execução de ações e a utilização de recursos educativos que expressem as concepções citadas. 


\section{A Lei n.o 11.274 de 2006}

A Lei n.o 11.274, aprovada em fevereiro de 2006, instituiu o ensino fundamental com nove anos de duração mediante a inclusão das crianças de seis anos de idade. Com isso, a nova organização do Ensino Fundamental passou a incluir dois novos elementos: os nove anos de trabalho escolar e a nova idade que integra esse ensino.

Para garantir uma nomenclatura comum às múltiplas possibilidades de organização desse nível de ensino (séries, ciclos, outros - conforme artigo 23 da LDBEN n. 9.394/96), o MEC sugere que o Ensino Fundamental seja mencionado conforme mostrado na Tabela.

\begin{tabular}{|c|c|c|c|c|c|c|c|c|}
\hline \multicolumn{9}{|c|}{ ENSINO FUNDAMENTAL } \\
\hline \multicolumn{5}{|c|}{ ANOS INICIAIS } & \multicolumn{4}{|c|}{ ANOS FINAIS } \\
\hline $1^{\circ}$ ano & $2^{\circ}$ ano & $3^{\circ}$ ano & $4^{\circ}$ ano & $5^{\circ}$ ano & $6^{\circ}$ ano & $7^{\circ}$ ano & $8^{\circ}$ ano & $9^{\circ}$ ano \\
\hline
\end{tabular}

Com relação à Educação para o Trânsito, foram estabelecidos os conteúdos apresentados a seguir, que respeitam a orientação do MEC no que diz respeito à organização do Ensino Fundamental, sendo referenciados no princípio da prevalência dos direitos humanos, estabelecidos na Constituição Brasileira e no Código de Trânsito Brasileiro.

\section{Conteúdos para os anos iniciais ( $\left(1^{\circ}\right.$ ao $5^{\circ}$ ano $)$}

\section{Os lugares}

Este bloco tem a função de promover situações que levem à observação, à exploração, à análise, ao debate e à produção de conhecimentos sobre os lugares onde os(as) alunos(as) vivem e que fazem parte de seu cotidiano: a casa, a escola, a rua de casa, a rua da escola, o bairro, o entorno. 


\section{A cidade}

Este bloco parte da cidade compreendida como lugar onde se pode praticar a vida, sendo o ponto de partida e o principal recurso educativo para trabalhar com questões relacionadas ao tema Trânsito.

\section{$\underline{O \text { direito de ir e vir }}$}

Este bloco pretende oferecer elementos que suscitem o debate sobre a necessidade e o direito que todas as pessoas têm de locomover-se com segurança no espaço público, bem como sobre a importância de conhecer e de respeitar as regras e as normas sociais e legais que regem tal direito.

\section{Conteúdos para os anos finais $\left(6^{\circ}\right.$ ao $9^{\circ}$ ano $)$}

\section{$\underline{\text { As linguagens do trânsito }}$}

A intenção deste bloco é explorar as diferentes linguagens utilizadas no trânsito, percebendo-as como forma objetiva de traduzir mensagens fundamentais à locomoção segura das pessoas no espaço público.

No trânsito, é possível encontrar, basicamente, três tipos de linguagem: a visual, baseada em ícones (figuras e imagens); a sonora, em sons emitidos pelo agente de trânsito, pelas buzinas dos veículos; e a gestual, em gestos dos agentes de trânsito, de condutores, pedestres, ciclistas, motociclistas e demais usuários das vias públicas. São estas linguagens que possibilitam a comunicação com o espaço público e no espaço público. Se as pessoas não decodificarem as mensagens transmitidas por meio das linguagens utilizadas no trânsito, causarão situações de conflito e acidentes. 
Os conteúdos deste bloco, especialmente aqueles relacionados à sinalização, devem ter como objetivo promover a análise e a compreensão das mensagens transmitidas. Compreender, neste caso, não significa repetir, memorizar ou, simplesmente, obedecer aos sinais de trânsito, mas descobrir suas razões pelo entendimento progressivo, a partir de vivências e de recursos educativos atraentes que incentivem a pesquisa, a observação e o estudo sobre o assunto.

Assim, os conteúdos partirão do universo cultural do(a) aluno(a) que, confrontado com o conhecimento formal, promoverá uma nova leitura da realidade, refletindo em mudança de atitude frente ao trânsito.

\section{Segurança no trânsito}

Todos os conteúdos enumerados até o momento envolvem, direta ou indiretamente, a palavra-chave do trânsito: segurança.

$\mathrm{Na}$ acepção da palavra, segurança é a qualidade ou condição do que é seguro, livre de risco. Sendo assim, os veículos devem ser seguros, as vias devem ser seguras, as calçadas devem ser seguras, enfim, o espaço público deve ser seguro, ou seja, livre de risco para todas as pessoas. Garantir a segurança neste espaço é tarefa dos órgãos públicos.

De acordo com o $\S 2^{\circ}$ do artigo $1^{\circ}$ do CTB:

O trânsito, em condições seguras, é um direito de todos e dever dos órgãos e entidades componentes do Sistema Nacional de Trânsito, a estes cabendo, no âmbito das respectivas competências, adotar medidas a assegurar este direito.

Neste bloco, é fundamental que os(as) alunos(as) compreendam que nenhuma atitude no trânsito pode ser considerada sob o ponto vista individual, uma vez que a adoção de comportamentos de risco expõe, também, a vida de outras pessoas. 
Portanto, a prática de ações livres de risco (ações seguras) é o princípio básico para impedir a ocorrência de acidentes no trânsito. No caso do trânsito, o significado da palavra acidente, como acontecimento casual, fortuito e imprevisto, perde o sentido, pois os acidentes de trânsito são, em regra, previsíveis, ou seja, podem ser evitados a partir da adoção de comportamentos seguros.

\section{Convivência social no trânsito}

Como já mencionado, nenhuma atitude no trânsito pode ser concebida sob o ponto de vista individual, pois todas as pessoas se locomovem num espaço público, isto é, num espaço que pertence a toda a coletividade. Neste espaço de relacionamento interpessoal, podem ser criadas situações harmoniosas ou de conflito.

Segundo o autor Eduardo Vasconcellos, existem dois tipos de conflito no trânsito: físico e político.

O conflito físico, mais aparente no trânsito, é caracterizado pela disputa do espaço: quando um pedestre quer atravessar a via no meio dos veículos ou quando dois veículos se aproximam ao mesmo tempo de um cruzamento. $\mathrm{O}$ conflito político reflete o interesse pessoal no trânsito, de acordo com as posições ocupadas em um determinado momento: quando a pessoa é pedestre, exige que os veículos parem para lhe dar passagem, mas quando dirige um veículo, reclama dos pedestres e não dá passagem.

É importante ressaltar que a posição das pessoas no trânsito muda constantemente. Isso possibilita o entendimento que não existem pedestres, condutores ou passageiros como seres imutáveis. Vem daí a importância de desenvolver atividades nas quais os(as) alunos(as) assumam diferentes posições e compreendam que os conflitos no trânsito só podem ser minimizados quando suas atitudes, independentemente da posição ocupada, estiverem voltadas ao bem comum. 
Assim sendo, este bloco deve enfatizar conteúdos que suscitem análises, reflexões e debates sobre o comportamento das pessoas no trânsito, não para sentenciar culpas, mas para favorecer aprendizagens que possam ser refletidas por meio de atitudes éticas e de cidadania.

\subsection{Proposta complementar}

Com base nas Diretrizes Nacionais para a Educação de Trânsito no Ensino Fundamental e considerando o resultado da pesquisa de campo do Projeto Rumo à Escola que observou a visão dos alunos sobre o tema, sugere-se o acréscimo complementar de conteúdos programáticos relacionados à engenharia e seus elementos no programa de ensino de trânsito dos alunos, de acordo com as séries de aprendizado, como segue.

\section{Anos iniciais - representados pelo $1^{\circ}$ ao $5^{\circ}$ ano escolar}

Dentro das temáticas lugares, cidade, e direito de ir e vir, introduzir conteúdos sobre:

1. O ambiente construído - retrata a interferência do homem no ambiente natural, através das edificações e postura de objetos nos espaços por onde circulamos, começando dentro da área da escola, passando pela rua local, pelo bairro e chegando ao espaço integral da cidade. Nesta fase, cabe discutir com os alunos o significado e a importância desta ação do homem, levantando os aspectos positivos, os negativos e as formas que temos para contribuir com a preservação das obras e melhor utilização dos espaços;

2. Distribuição equitativa do espaço - retrata o momento em que temos de organizar estas obras e objetos para definir as diferentes áreas de circulação em relação aos diversos meios de se transportar. Discutir sobre as dificuldades de se ter o mesmo quantitativo de espaço para todos os meios de transporte. Verificar com os alunos como eles definiriam prioridades dentro da escola, por exemplo, em relação ao deslocamento a pé, com uma bicicleta, entre o funcionário ou professor com mais idade e os demais, os que transportam panelas ou objetos pesados e os que estão com as mãos livres, etc. 


\section{Anos finais - representados pelo $6^{\circ}$ ao $9^{\circ}$ ano escolar}

Dentro das temáticas linguagens do trânsito, segurança e convívio social, introduzir conteúdos sobre:

3. Sistema viário - retrata a construção das vias (pavimentadas ou não) e a introdução de elementos físicos indicativos de espaço próprio para a circulação. Nesta fase, cabe discutir com os alunos a necessidade de se definir espaços específicos de circulação dos veículos e dos pedestres e a importância para se ter uma mobilidade e acessibilidade mais adequadas nas cidades;

4. Elementos de comunicação na via - retrata aspectos da sinalização vertical, horizontal e semafórica. Não se trata de ensinar para os alunos o significado das placas de trânsito, mas sim de saberem identifica-las como elementos de comunicação entre o poder público e a população. Abordar a necessidade e a importância de se respeitar os sinais, mencionando as cores e as formas básicas. Observar se os alunos identificam e sabem utilizar, por exemplo, o sinal semafórico destinado ao pedestre (botoeira). Estabelecer comparações com a sinalização interna da escola, indicando salas, auditório, banheiros - por meio de escrita e simbologia - para mostrar que nas vias o uso do espaço requer também orientação aos usuários;

5. Passagens de pedestre e ciclista - retrata uma atenção especial para a sinalização da faixa de pedestre, passarelas, das ciclofaixas e ciclovias. Discutir a questão do posicionamento destes elementos no sistema viário em relação às expectativas e necessidades de uso da população. Verificar meios de participação da comunidade quando da elaboração de projetos e implementação destes elementos de sinalização e das obras de arte da engenharia, visando garantir a proximidade com as reais necessidades e expectativas;

6. Sinalização e elementos da engenharia para o transporte coletivo - retrata as possibilidades da cidade, mediante o uso da engenharia, dar prioridades ao transporte coletivo e organizar o transporte escolar. Discutir sobre os pontos positivos de uma faixa exclusiva ou preferencial para ônibus em determinadas 
áreas da cidade. Verificar como anda a informação (comunicação) do poder público, através da engenharia, quanto às linhas de ônibus, aos locais de parada, aos tempos de circulação;

7. Elementos de engenharia, segurança e convivência em sociedade - retrata a relação direta da interferência da engenharia no sistema viário com os aspectos da segurança do cidadão em seu deslocamento diário e com a divisão de espaço e convívio entre as pessoas. Discutir a questão da ética (bem comum) quando se estabelece restrições a alguns com os elementos de engenharia postados na via, a exemplo das proibições por placa, limitações ou condições de uso (estacionamento rotativo), dentre outros. Trabalhar o trânsito com a ótica de vida e a engenharia e seus elementos como intermediária técnica de organização do espaço público. 


\section{7 \\ CONCLUSÕES}

O Brasil cresceu em termos de população e, em curto espaço de tempo, transformou pequenos vilarejos em grandes cidades e metrópoles. Este desenvolvimento se fez acompanhar das mudanças nas formas e meios de deslocamentos das pessoas, com direcionamento, significativo, para o uso do automóvel e equipamentos individuais de locomoção. Assim, em cinco décadas, a frota brasileira de veículos atingiu a casa dos 58.000 .000 (cinqüenta e oito milhões) - conforme dados oficiais do Departamento Nacional de Trânsito (Denatran) -, seguida do avanço tecnológico da engenharia mecânica e automobilística e da engenharia de tráfego. As tentativas de regular e organizar esta nova forma de circular das pessoas, com o uso do automóvel, foram seguidas de diferentes normas e leis, sendo, no momento atual - ano de 2010 -, a principal delas definida na Lei 9.503/97, que instituiu o Código de Trânsito Brasileiro.

Os argumentos e conceitos teóricos defendidos nesta tese, aliados ao trabalho de pesquisa de campo realizado pelo Projeto Rumo à Escola, mostram, com clareza, que a educação para o trânsito é o caminho imprescindível a ser seguido para se reduzir o volume de dificuldades e problemas existentes no uso do espaço público urbano e rural de nossos municípios, refletidos, principalmente, nos elevados índices de acidentes e no conflito social. É, também, notório que, no caso brasileiro, a educação para o trânsito não tem merecido a importância que deveria ter, sendo necessário implementar as propostas existentes, representadas nas Diretrizes Nacionais da Educação para o Trânsito no Ensino Fundamental, e aperfeiçoar os conteúdos programáticos a serem disseminados nesta fase do ensino.

Ao defender, nesta tese, o argumento da educação para o trânsito por meio da utilização do processo pedagógico da transversalidade, fez-se necessário discutir o conceito ampliado do tema trânsito, as bases legais que regem a educação no Brasil e os argumentos da Psicologia que descrevem o processo de ensino-aprendizagem em suas diferentes etapas. O argumento da transversalidade, defendido nesta tese, se torna mais sólido quando, no capítulo 4, apresenta e discute os resultados práticos da pesquisa de 
campo realizada pelo Projeto Rumo à Escola, trabalho desenvolvido em parceria com a Unesco e o Denatran, e que implementou, em caráter experimental, a proposta de educação para o trânsito, no modo da transversalidade, em quinze capitais brasileiras, atingindo um universo de 19.000 (dezenove mil) professores e 300.000 (trezentos mil) alunos da rede do Ensino Fundamental.

Em visita às capitais, em 2008 e 2009, que integraram o Projeto Rumo à Escola, pôdese verificar que algumas das escolas que haviam adotado o ensino de trânsito na transversalidade ainda permaneciam trabalhando o tema trânsito, dentro dos moldes orientados pelo Projeto. Ou seja, a escola e professores internalizaram a filosofia e os métodos de trabalho iniciados na experiência implementada pela parceria Denatran e Unesco. Estados, como Santa Catarina, verificou-se que das quinze escolas iniciais do Projeto, em sete delas os professores mantinham o tratamento de conteúdos programáticos transversais em suas disciplinas, envolvendo a questão do trânsito. Este fato é um possível indicador do marco diferencial quando se trabalha a educação para o trânsito usando a transversalidade.

Considerando o aspecto das leis em defesa do argumento da transversalidade destaca-se o previsto no artigo 76 do Código de Trânsito Brasileiro (CTB), onde cita a obrigatoriedade de se adotar na rede escolar - em todos os seus níveis de ensino conteúdos programáticos relacionados com a segurança de trânsito. Por sua vez, os Parâmetros Curriculares Nacionais (PCN) apontam o caminho para as escolas trabalharem temas considerados de urgência social e de abrangência nacional, através da transversalidade. No caso específico do tema trânsito, esta orientação se torna clara e indiscutível quando o Conselho Nacional de Educação emite o Parecer de N. 22/2004, onde define a impossibilidade de se trabalhar o trânsito nas escolas sob a forma de disciplina, determinando ao órgão máximo executivo de trânsito da União que produza materiais e orientações para que se possa atuar com esta temática nos moldes já consolidados na prática pedagógica das escolas.

Não há dúvidas de que é possível melhorar o convívio social no uso do espaço urbano, transformando o conflito em respeito, através da educação. Neste sentido, os conceitos e argumentos, discutidos no capítulo 3, defendidos pela Psicologia no processo de ensinoaprendizagem dão conta de que o "Ser Humano começa a aprender quando nasce e só 
para de aprender quando deixa de existir" ( CAMPOS, 1991), o que reforça a ideia de se trabalhar a educação para o trânsito desde o início da fase escolar. Ainda, durante a execução do Projeto Rumo à Escola, em conversas informais com os professores, percebia-se a unanimidade em afirmar que os alunos da escola que tinham a oportunidade de discutir o tema trânsito dentro das disciplinas apresentavam atitudes e comportamento mais seguros nos deslocamentos dentro do espaço físico da escola e na via, nas proximidades de entrada e saída do estabelecimento de ensino.

Contudo, a solidez dos argumentos em defesa da transversalidade se completa quando, no capítulo 4, discute-se os resultados do trabalho de campo obtidos pelo Projeto Rumo à Escola na implementação experimental da educação para o trânsito na rede escolar do Ensino Fundamental. Antes das escolas participantes do Projeto iniciarem o ensino de trânsito nos moldes da transversalidade, pôde-se verificar que os alunos concentravam uma imagem do trânsito muito negativa, de conflito no uso do espaço urbano e percebido, basicamente, nos elementos de engenharia de tráfego colocados sobre o sistema viário. A pesquisa aponta que o semáforo, a via, o meio de locomoção, a sinalização com placas e os pedestres, juntos, somam 82,9\% das imagens representadas em desenhos pelos alunos. Percebe-se, daí, que o imaginário destes alunos está voltado para um trânsito violento e, muitas das vezes, trágico, com acidentes e mortes, e estes fatos vinculados aos elementos viários dispostos pela engenharia. A partir da discussão do tema trânsito na transversalidade, esta visão dos alunos vai sendo alterada para entender a possibilidade de se ter um deslocamento mais seguro, com base no respeito e na construção e prática de valores sociais que contribuem para o exercício pleno da cidadania.

Não obstante às dificuldades da União em atuar, de modo permanente, na implementação da educação para o trânsito nas escolas, a crescente necessidade do país se mobilizar e definir estratégias mais concretas em relação à mudança de atitude das pessoas no ato de seus deslocamentos fez com que, no ano de 2009, o Departamento Nacional de Trânsito (Denatran), cumprindo as orientações definidas no Parecer de N.22/2004 do Conselho Nacional de Educação (CNE), publicasse a Portaria de N.147/2009, que aponta as Diretrizes Nacionais da Educação para o Trânsito na PréEscola e no Ensino Fundamental. Assim, com base neste documento da União, na Proposta psicopedagógica de Rozestraten (apresentados no capítulo 6) e considerado a 
presença marcante da engenharia de tráfego e seus elementos na visão de trânsito dos alunos, mostrada por meio da pesquisa de campo do Projeto Rumo à Escola, foi possível definir proposta de conteúdo complementar de educação para o trânsito a ser inserido no processo de ensino-aprendizagem dos alunos do Ensino Fundamental.

Cabe ressaltar, contudo, que o trabalho desenvolvido nesta tese apresenta limitações e que poderão ser aperfeiçoadas em projetos acadêmicos posteriores. Dentre as limitações cita-se o fato do estudo ser específico para o Ensino Fundamental, não abrangendo a Pré-Escola, o Ensino Médio e o Ensino Superior. Ainda, a proposta complementar de inclusão de conteúdos programáticos de trânsito, segundo a visão dos alunos, e apresentada nesta tese pode ser confirmada através de pesquisa específica de implementação em escolas da rede do Ensino Fundamental. A proposta em si encontrase validada pela metodologia de acompanhamento do ensino transversal de trânsito nas escolas, exercida durante a execução do Projeto Rumo à Escola e que detectou a percepção dos alunos envolvendo os elementos de engenharia e sua associação negativa e desarticulada das questões de segurança.

Por fim, tem-se que os argumentos e conceitos teóricos discutidos nesta tese e a análise dos resultados da prática pedagógica dos professores, nas escolas de Ensino Fundamental, obtidas com a pesquisa de campo realizada pelo Projeto Rumo à Escola, permitem afirmar:

- Que educar para o trânsito é fator fundamental para a vida da população, de uma sociedade, retratando sua possibilidade de se deslocar para o exercício das mais diversas atividades, como trabalho, estudo, saúde, lazer. Integrado a um adequado sistema de transporte e respeitado o seu caráter multidisciplinar, a educação para o trânsito contribui para o exercício pleno da cidadania;

- Que a forma mais adequada de encaminhar o processo educativo e de aprendizado de trânsito dentro da escola, na rede de Ensino Fundamental, passa pela adoção da transversalidade do tema, sendo esta viável, prática e respaldada na legislação brasileira; 
- Que a transversalidade de temas de urgência social e abrangência nacional já é prática na realidade das escolas, principalmente a rede do Ensino Fundamental;

- Que a estrutura física e a logística existente na rede escolar, aliadas à orientação pedagógica dos professores, possibilitam a introdução do assunto trânsito, com base nos conceitos definidos pela Lei de Diretrizes e Bases da Educação Nacional (LDBEN) e nos Parâmetros Curriculares Nacionais (PCN), atendendo, também, aos propósitos definidos no artigo 76, da Lei Federal de N. 9.503/97 que instituiu o Código de Trânsito Brasileiro (CTB);

- Que existe a necessidade de se introduzir, no processo de ensino, conteúdos complementares relacionados à engenharia de tráfego e demais elementos dispostos na via, partindo da visão dos alunos sobre trânsito.

- E, por fim, que é possível transformar o espaço de deslocamento num espaço de respeito entre as pessoas, preservando valores sociais, tendo como base o princípio da Psicologia em que "o Ser Humano começa a aprender quando nasce e só para de aprender quando deixa de existir" (CAMPOS, 1991); 


\section{REFERÊNCIAS BIBLIOGRÁFICAS}

ALMEIDA, Cláudio A . Cultura e sociedade no Brasil: 1940 -1968, Atual, 1996.

ALVAREZ, Maria Niéves (et al.). Valores e temas transversais no currículo, Artmed, 2002

ARNHEIM, R. Arte e Percepção Visual: uma psicologia da visão criadora. São Paulo: Pioneira, Edusp, 1980.

ARAGÃO, Samuel Correia. Trânsito na Europa: conheça o trânsito na Europa, editora Unigraf, 1997.

ASSOCIAÇÃO BRASILEIRA DE NORMAS TÉCNICAS - ABNT. Norma NBR-ISO9001 e 9002 - Modelos para garantia da qualidade, 1994.

ASSOCIAÇÃO NACIONAL DE TRANSPORTES PÚBLICOS - ANTP. Anais do VI Encontro Nacional/NE de Transportes Públicos. ANTP, junho, 1996 $18 \mathrm{p}$.

Transporte Humano: Cidades com Qualidade de Vida. ANTP, 1997.

AUMONT, Jaques. A imagem. São Paulo, Editora Papirus, 1995.

BARTHES, Roland. A Câmara Clara. Rio de Janeiro, Editora Nova Fronteira, $5^{a}$ impressão, 1980.

BENDAVID-VAL, Leah. Um século de fotografia. Trad. Suzana Schindler. São Paulo: Klick Editora, 1995. 
BRASLAVSKY, Cecília. Aprender a viver juntos: educação para a integração na diversidade, UNESCO, IBES, SESI, UnB, 2002.

CAMPOS, Dinah Martins de Souza. Psicologia da Aprendizagem. Petrópolis, Vozes, 22a edição, 1991.

CAUDURO, Martino Arquitetos Associados Ltda. Pré-manual do sistema de comunicação visual dos transportes públicos. São Paulo: S. n. , S. d.

CHIAPPINI, Ligia. Aprender e ensinar com textos de alunos, Cortez, 2001

CIA. DE ENGENHARIA DE TRÁFEGO - CET. Curso de aperfeiçoamento para técnicos de treinamento e educação de trânsito. CET, São Paulo, 1995.

CIA DE ENGENHARIA DE TRÁFEGO - CET. Educação de trânsito via comunicação social. Boletim Técnico, nº 23. CET, São Paulo, 1979. 84 p.

COMISSÃO ANTP DE PESQUISA DE OPINIÃO. A opinião do usuário como indicador de qualidade. Revista dos Transportes Públicos, ano 17, $2^{\circ}$ trimestre de 1995. ANTP, São Paulo, 1995.

CONGRESSO NACIONAL. Código de Trânsito Brasileiro: Lei 9.503 / 97. Brasília, 1997.

CORRÊA, J. PEDRO. 20 Anos de Lições de Trânsito: Desafios e Conquistas do Trânsito Brasileiro de 1987 a 2007. Curitiba: Volvo, 2009.

CRESPO, Antônio Arnot. Estatística fácil. São Paulo, edit. Saraiva, 16ª ed., 1998. 
DEPARTAMENTO NACIONAL DE TRÂNSITO - DENATRAN. Manuais de Sinalização e Engenharia de Tráfego.

DePARTAMENTO NACIONAL DE TRÂNSITO - DENATRAN. Portaria $147 / 2009$.

DIAS BORDENAVE, Juan E. O que é comunicação. São Paulo: Brasiliense, 1985.

DIMENSTEIN, Gilberto. Aprendiz do futuro: cidadania hoje e amanhã, Ática, 2002.

DOCZI, G. O poder dos limites - harmonias e proporções na natureza. Arte e Arquitetura, São Paulo: Mercuryo, 1990.

DONDIS, Gisele. Sintaxe da linguagem visual. São Paulo: Martins Fontes, 1991.

FAZENDA, Ivani. Didática e interdisciplinaridade, Papirus, 1998. Interdisciplinaridade - um projeto em parceria, Loyola, 2002.

FERRAZ, A. C. P.; RAIA JUNIOR, A. A.; BEZERRA, Bárbara Stolte. Segurança no trânsito. São Carlos: NEST, 2008.

FERRAZ, A. C. P.; TORRES, I. G. E. Transporte Público Urbano. 2. ed. São Carlos: Rima, 2004. 410p.

FILHO, V. P. Aspectos da educação de trânsito decorrentes das proposições das teorias de segurança. Revista Transportes, junho 2004, Vol.XII, N.1, págs. 59-68. 
FREIRE, Paulo. A educação na cidade, Cortez, 2002.

FORGUS, R. H. Percepção, o processo básico de desenvolvimento cognitivo. São Paulo, Herdes, 1981.

FURTER, Pierre. Educação e Vida. Petrópolis, Vozes, 11ª edição, 1987.

GIL, Antônio Carlos. Métodos e técnicas de pesquisa social. $2^{\mathrm{a}}$ edição, Atlas Ed., São Paulo, 1987.

GREENPEACE BRASIL. Cidades livres de carros. 1993. 43 p.

Máquina mortífera - carros, transporte urbano, poluição. 1996. $16 \mathrm{p}$.

HANNAS \& PEREIRA, Maria Lúcia \& Ieda Lúcia. Nova prática pedagógica vol II - propostas para uma nova abordagem curricular, editora Gente, 2002.

HERR, Nicole. 100 Fichas práticas para explorar o jornal na sala de aula, editora Dimensão, 1997

HONIGSZTEN, Henrique. A psicologia da criação. Rio de Janeiro: Imago Editora, 1990.

INSTITUTO BRASILEIRO DE ADMINISTRAÇÃO PÚBLICA - IBAP. Institucionalização da participação popular nos municípios brasileiros. Cadernos, no 1. IBAP, Forja, 1996.

INSTITUTO DE PESQUISAS ECONÔMICAS APLICADAS - IPEA. Impactos Sociais e Econômicos dos Acidentes de Trânsito, Brasília, 2006. 
ITO, Mauro Yoshio; BEREZOVSKY, Ilana; PENNA, Susana Nunes. Conselho Estudantil de Acidentes de Trânsito - Cepat. Notas Técnicas, no 31. CET, São Paulo, 1995.

IVENS, F. Decomposição da Forma. Curitiba: Col. Forma e Cor, Ed. Itaipu, s/d.

JOHANSSON, G. \& RUMAR, K. Drivers and road signs: a preliminary investigation of the capacity of car drivers to get information from road signs. Ergonômics, 9: 57- 62, 1966.

$\mathrm{KÖCHE}$, José Carlos. Fundamentos de metodologia científica. Teoria da ciência e prática da pesquisa. Petrópolis/RJ: Editora Vozes, $15^{\mathrm{a}}$ ed.,1997.

LEGGE, D. \& BARBER, P. J. Informação e Habilidade, CBP-A5. Tradução Álvaro Cabral, Rio de Janeiro: Zahar ed, 1977.

LEGGE, D. \& BARBER, P. J. Percepção e Informação, Rio de Janeiro: Zahar, 1976.

LOO, R. Individual differences and the perception of traffic signs, human factors. 20 (1), 65 - 74, 1979.

LÜCK, Heloísa. Pedagogia interdisciplinar: fundamentos teóricometodológicos, Vozes, 1994.

METZ, Cristhian et alii. A análise das imagens. Rio de Janeiro, Vozes, 1973.

MINAYO, Maria Cecília de Souza. Fala galera: juventude, violência e cidadania, editora Garamond, 1999. 
MINISTÉRIO DA EDUCAÇÃO. Legislação sobre a educação no Brasil MOLES, Abraham. Teoria da informação e percepção estética. Brasília, Editora UnB, 1978. . Teoria dos objetos. Edições Tempo Brasileiro, 1981.

MUNARI, Bruno. Design e Comunicação Visual. São Paulo: Martins Fontes, 1997.

NISKIER, Arnaldo. Tecnologia Educacional: uma visão política. Petrópolis, Vozes, 1993.

NÖTH, Winfried \& SANTAELLA, Lúcia. Imagem - cognição, semiótica, mídia. Editora Iluminuras Ltda, 1998.

PINTO, Eduardo. Fotojornalismo: informação e arte a serviço da história, 1999.

PINSKY, Jaime. Cidadania e educação, Contexto, 2002.

POTTIER, A \& LAYA, O . Perception visuell et ergonomic transports. Cutes INRETS n 27, 1993.

RABAÇA, Carlos Alberto \& BARBOSA, Gustavo. Dicionário de Comunicação. São Paulo: Ática, 1987.

REDIG, Joaquim. Forma e conteúdo. LBDI, Agosto, 1991.

RICHARD, J. F. Attention. Paris: P.U.F, 1980 
RODRIGUES, Rosicler Martins. Cidades brasileiras: o passado e o presente, editora Moderna, 1998

RODRIGUES, Juciara. $\mathbf{5 0 0}$ anos de trânsito no Brasil. DENATRAN/UNESCO, 2000. . Educação de Trânsito no Ensino Fundamental: caminho aberto à cidadania, editora ABDETRAN, 1999. - Motorista e pedestre: passo a passo conquistando seu espaço, editora Formato, 1999.

ROZESTRATEN, R. S. A. Os sinais de trânsito e o comportamento seguro. Porto Alegre: Sagra, 1996.

ROZESTRATEN, R. S. A . Psicologia do Trânsito: conceitos e processos básicos. São Paulo: EPU-EDUSP, 1988.

ROZESTRATEN, R. S. A . Psicopedagogia do trânsito: princípios psicopedagógicos da educação transversal para o trânsito para professores do Ensino Fundamental. Campo Grande: UCDB, 2004.

SAUSMAREZ, Maurice. Desenho básico. As dinâmicas da forma visual. Lisboa, Presença, 1979.

SANTAELLA, Maria Lúcia. Por uma classificação da linguagem visual. In: face. Revista de Semiótica e Comunicação, EDUC, 2 (1), 1989.

SILVA, Jair Militão. Os educadores e o cotidiano escolar, Papirus, 2002.

SOUZA, José Leles de. Cidadania e Educação para o Trânsito. Dissertação de Mestrado. Universidade de Brasília, Transportes Urbanos, 1995. 
Unitede Kingdom - Department of the Environment. Bus priority. Proceedings of a Symposium held at Transport and Road Research Laboratory - TRRL, 1992

VASCONCELLOS, Eduardo Alcântara. Transporte urbano, espaço e equidade. Unidas, São Paulo, 1996.

VASCONCELLOS, Eduardo Alcântara. O que é trânsito. Brasiliense, São Paulo, 1998.

WERTHEIN \& CUNHA, Jorge e Célio. Fundamentos da nova educação, UNESCO, 2000.

YUS, Rafael. Temas transversais: em busca de uma nova escola, Artmede, 1998. 
ANEXO. Ações e Projetos de educação para o trânsito implementados por instituições públicas federais no Brasil

A maior parte das ações de governo em relação a educação para o trânsito tem sido através de campanhas educativas, veiculadas na mídia eletrônica, sazonais. Refere-se a propagandas abordando temáticas como álcool e volante; velocidade e respeito às leis de trânsito. Estas campanhas são intensificadas nos períodos de festas típicas, como o carnaval e semana santa e, em alguns momentos, foram acompanhadas da distribuição de folhetos educativos abordando temas similares.

Em relação a projetos de maior duração destacam-se as seguintes ações da União:

Em 02 de julho de 1993, através da Portaria Ministerial 621, o Ministério dos Transportes criou o Programa de Redução de Acidentes nas Estradas - PARE, cujo nome hoje é Programa de Redução de Acidentes no Trânsito. Seu objetivo é o de combater os altos índices de acidentes de trânsito, tendo por base o resgate da postura de cidadania e utilizando-se de alternativas que resultem em uma convivência harmônica, preventiva e defensiva no cotidiano das ruas e estradas brasileiras.

Estruturado com uma Coordenação Geral, em Brasília, e Coordenadorias Regionais (Sul, Sudeste, Nordeste, Norte e Centro-Oeste), o programa instituiu também os Núcleos de amigos, familiares e vítimas em trânsito. Ressalta-se que, as ações dos Coordenadores Regionais e dos Núcleos não eram remuneradas, mas sim voluntárias.

As metas do PARE estavam pautadas em:

- Conscientização dos motoristas profissionais e amadores;

- Conscientização dos pedestres;

- Mobilização da opinião pública;

- Sensibilização das Autoridades Públicas;

- Desenvolvimento de processos técnicos e científicos na avaliação de resultados;

- Instituição de um arquivo de dados e informações nacionais.

Destacam-se as seguintes ações desenvolvidas: 
- PARE SUL 93/94

Esta ação foi desenvolvida com o objetivo de transmitir aos turistas platinos o significado da sinalização de trânsito brasileira e o comportamento adequado em nossas estradas. De acordo com a Polícia Rodoviária Federal, esta ação significou uma redução de $70 \%$ no número de morte dos turistas, causadas por acidentes de trânsito, em relação ao ano anterior.

- 25 DE JULHO DE 94/95 - DIA NACIONAL PELA PAZ NAS ESTRADAS

Ação desenvolvida em âmbito nacional, veiculada pelos principais meios de comunicação de massa e cujo público direto atingido foi estimado em 1.000 .000 de pessoas. Nesta data foram entregues diversos panfletos e promovidos cultos ecumênicos em diversas capitais do país.

- SEMANA DA CRIANÇA

Trabalho realizado de orientação às crianças para uma postura preventiva no trânsito. Foram confeccionadas, à época, 1.000.000 de revistas em quadrinhos com título "Ararajuba", cumprindo um papel fundamental na formação de opinião dos jovens e conseqüentes interferências destes com relação à maneira de condução do veículo pelos pais. A revista era distribuída em encartes de jornais de grande circulação e teve o patrocínio da PETROBRÁS.

- CARAVANA PELA PAZ NAS ESTRADAS

Considerado o maior evento produzido pelo PARE, esta caravana percorreu as principais capitais do país, mobilizando cerca de 10.000 .000 de pessoas, tendo ampla cobertura dos meios de comunicação de massa do país. Teve início na cidade de Passo Fundo/RS, no dia 12 de julho de 1995, passando pelos Estados de Santa Catarina, Paraná, São Paulo, Rio de Janeiro, Minas Gerais, Goiás e chegando ao Distrito Federal, no dia 25 de julho, após ter percorrido 75 cidades. 
A caravana portava uma "chama", espécie de pira olímpica, que foi recebida, no Palácio do Planalto, pelo então Presidente da República Fernando Henrique Cardoso. Neste dia foram feitos os lançamentos de dois selos comemorativos do Programa PARE, com 2.000.000 de tiragens feitas pelos Correios, e também um cartão telefônico com alusão ao tema trânsito, que teve 1.500 .000 exemplares produzidos pela Telebrás.

Juntamente com a "chama", foi entregue ao Exmo. Sr. Presidente um livro contendo mais de 1.000.000 de assinaturas, coletadas ao longo da caravana, pedindo a aprovação imediata do Código de Trânsito Brasileiro - CTB, que se encontrava no Congresso Nacional a quase oito anos. Este ato resultou em um pedido, do Presidente ao Congresso, de urgência urgentíssima para a aprovação do CTB.

- Em 2002 e 2003, o PARE lançou e implementou o projeto "Amigo da Vez", amigo que dirige não bebe. A ação contempla material educativo impresso, bonés, camisetas e apresentação em bares da cidade de uma peça alertando sobre os riscos do beber e dirigir, estimulando a cultura do amigo da vez.

Mapa de percurso da Ação "Caravana pela Paz no Trânsito"

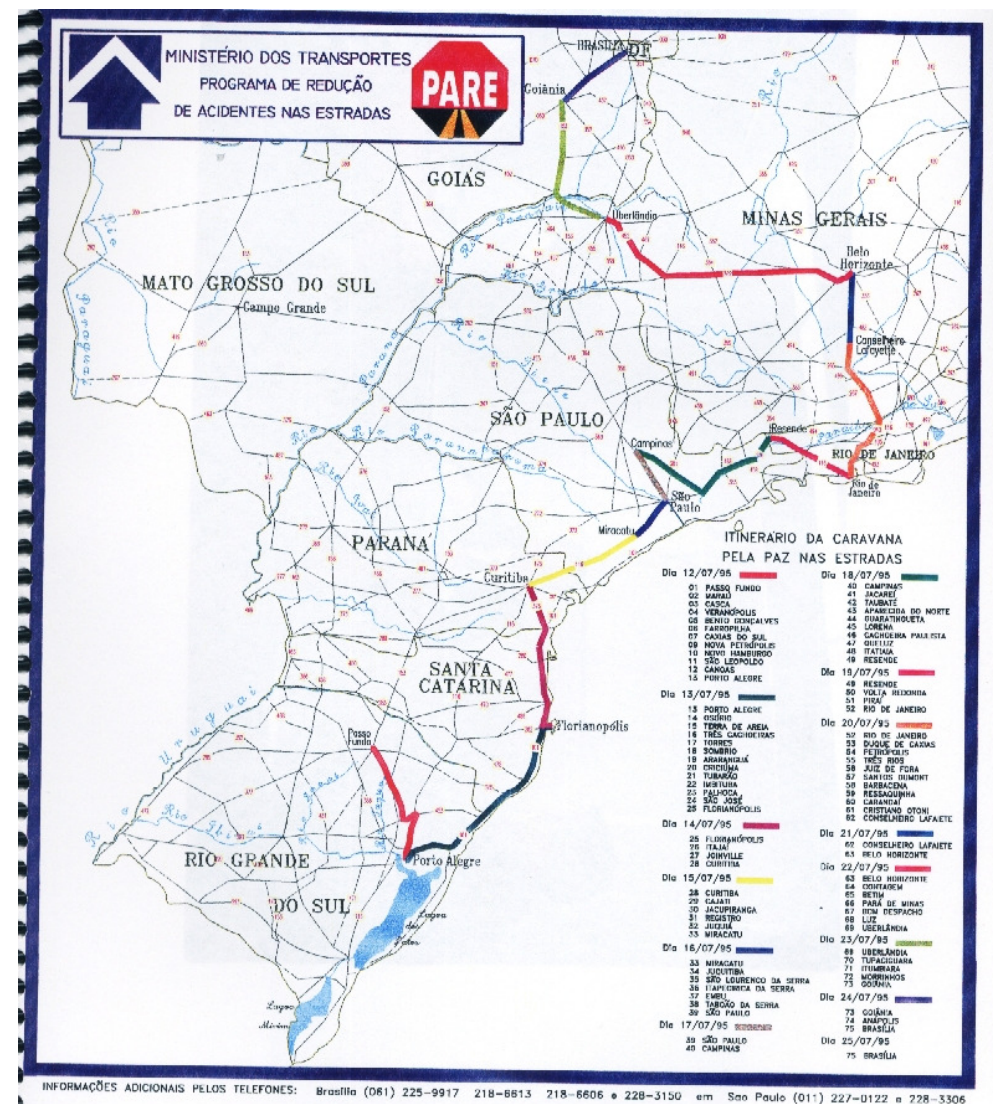


- CENTRO DE REFERÊNCIA NACIONAL DE ATENDIMENTO AO TRABALHADOR EM TRANSPORTES

Em parceria com o Instituto de Ortopedia e Traumatologia da Faculdade de Medicina do Hospital das Clínicas da Universidade de São Paulo, com a Confederação Nacional dos Transportes - CNT, com o SEST/SENAT e a Organização Internacional do Trabalho - OIT, o PARE viabilizou este Centro para o desenvolvimento de três atividades básicas: Assistência médica especializada em procedimentos de alta complexidade; Pesquisa na área clínica, biomecânica e ergonomia, voltadas ao trabalhador em transporte; e Treinamento de profissionais da área de saúde.

Dentre as atividades desenvolvidas neste Centro ressalta-se o Laboratório do Movimento Humano, com uso do recurso Cybex 6.000, que faz uma avaliação funcional dos condutores; $\mathrm{O}$ estabelecimento do perfil social, biológico e psicológico do trabalhador em transportes; A avaliação da pressão arterial dos motoristas profissionais, com o uso de holters de 24 horas, durante seu período de trabalho e o perfil do consumo de álcool e drogas por condutores acidentados.

Em 11 de dezembro de 1996, através do Decreto 2.093 da Presidência da República, o governo federal cria o GERAT - Grupo Executivo de Redução de Acidentes de Trânsito. De acordo com o Decreto, competia ao GERAT analisar, implantar e coordenar medidas que viessem a contribuir para a redução do número e da gravidade dos acidentes no trânsito; Adotar medidas visando a ação integrada dos órgãos de fiscalização do trânsito, de educação, saúde e trabalho; Integrar suas ações com as do Programa PARE.

Dentre as diversas ações implementadas pelo GERAT destacam-se os Encontros Técnicos, os Mutirões de Férias pela Paz nas Estradas, e a campanha de educação da criança e do adolescente "Siga o Seninha, S. O. S para o Trânsito". Este último, articulado pelo GERAT, teve o apoio técnico e institucional do Departamento Nacional de Trânsito - DENATRAN, o patrocínio do Banco do Brasil, através da Brasil Veículos, e as parcerias do Instituto Ayrton Senna e o Jornal O Globo. 
Siga o Seninha foi um encarte mensal, contendo informações de procedimentos para as crianças e cujo personagem central era o "Seninha". As orientações técnicas eram formatadas pelo DENATRAN, a história e os desenhos feitos pelo Instituto Ayrton Senna e a produção e distribuição do material feita pelo jornal O Globo. Este trabalho educativo foi desenvolvido ao longo do ano de 1998.

Fotos representativas das ações: Caravana pela Paz e Amigo da Vez

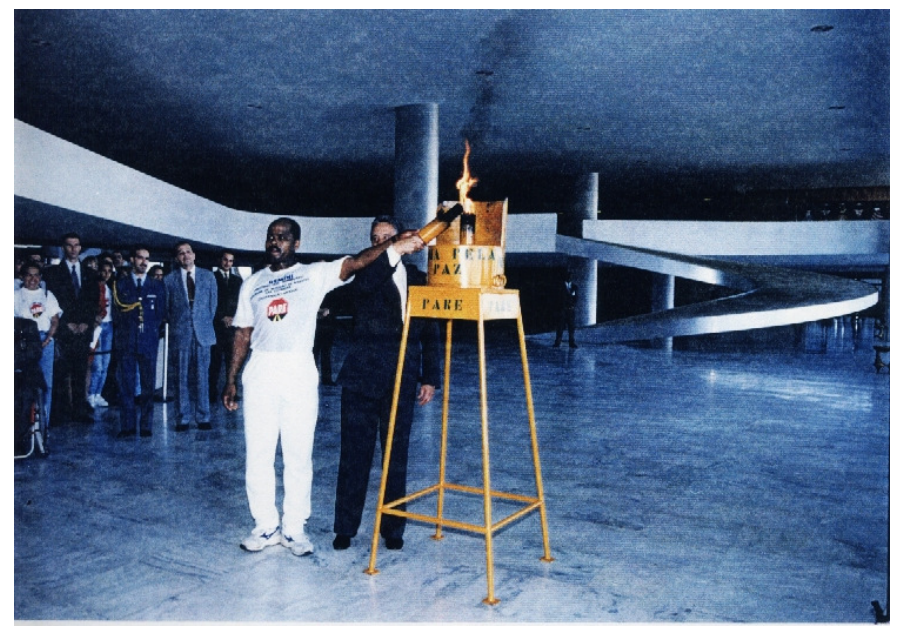

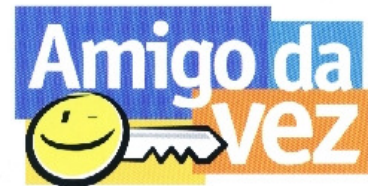

AMIGO QUE DIRIGE NÃO BEBE.

MINISTÉRIO DOS TRANSPORTES

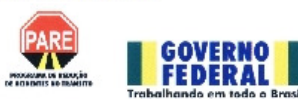

Outro significativo projeto de educação efetivado pela União foi o "Rumo à Escola". Nascido da parceria de Cooperação Técnica entre o Departamento Nacional de Trânsito - DENATRAN, à época pertencente ao Ministério da Justiça, e a União das nações Unidas para a Educação, Ciência e Cultura - UNESCO, o projeto começou a ser implementado nas Escolas em outubro de 2001.

Com duração prevista para 26 meses e tendo sido orçado em $\mathrm{R} \$$ 8.595.457,00 (oito milhões, quinhentos e noventa e cinco mil, quatrocentos e cinqüenta e sete reais), a serem pagos pelo Fundo Nacional de Segurança e Educação de Trânsito - FUNSET, o Projeto objetiva implementar o tema trânsito como prática educativa cotidiana em escolas do Ensino Fundamental, subsidiando-as por meio de consultoria educacional como suporte à fundamentação teórica e à orientação do desenvolvimento de atividades em sala de aula. 
Em sua proposta, busca inverter a concepção de trânsito - até então assimilada pela sociedade brasileira, especialmente no decorrer das últimas décadas - na qual está apresentada de forma restrita e enfocando aspectos extremamente negativos. A idéia é que as escolas possam discutir o trânsito sob o enfoque do direito de ir e vir, de ocupar o espaço público, de conviver socialmente neste espaço. Assim, o Projeto substitui o tradicional conceito de trânsito envolvendo "Homem, Veículo e Via" para o conceito mais abrangente enfocando a "Locomoção, a Comunicação e o Convívio Social”.

Com o Rumo à Escola o DENATRAN esperava contribuir na preparação da geração atual para uma sociedade mais justa e solidária, ampliando conhecimentos e valorizando comportamentos éticos. Ao abordar o tema trânsito nas escolas, deixaria como legado aos municípios participantes uma nova concepção, mais ampla e comprometida com o princípio básico da educação para a cidadania.

O pensamento era o de que adotando uma metodologia ancorada sob essa concepção, ao final do Projeto, as escolas envolvidas e os órgãos gestores de trânsito e de educação municipais contariam com um grupo de profissionais capacitados e material educativo adequado ao desenvolvimento de atividades sistemáticas relacionadas ao trânsito.

O Rumo à Escola foi estruturado com uma Coordenação Nacional, em Brasília, composta por 10 técnicos e equipes de técnicos nas regionais, média de dois em cada uma das 15 capitais onde o Projeto foi implementado inicialmente. Comumente denominados de "Núcleo Central" e "Núcleos Regionais".

Ressalta-se que diversas ações e projetos, buscando a educação no trânsito, foram desenvolvidas e implementadas por vários Estados e Municípios brasileiros ao longo da década de 90, bem como inúmeros projetos específicos advindos da iniciativa privada, a exemplo do Programa Volvo de Segurança no Trânsito, da FIAT - Moto Perpétuo, o recém criado FIAT - Apita, os Programas de Capacitação Profissional e Treinamento do ICETRAN/SC - Instituto de Certificação e Estudos de Trânsito e Transportes, dentre outras desenvolvidas também por Universidades e Escolas da rede pública e privada. 
Fotos representativas das Ações "Seninha", "Cartão Telefônico" e "Selos Comemorativos".
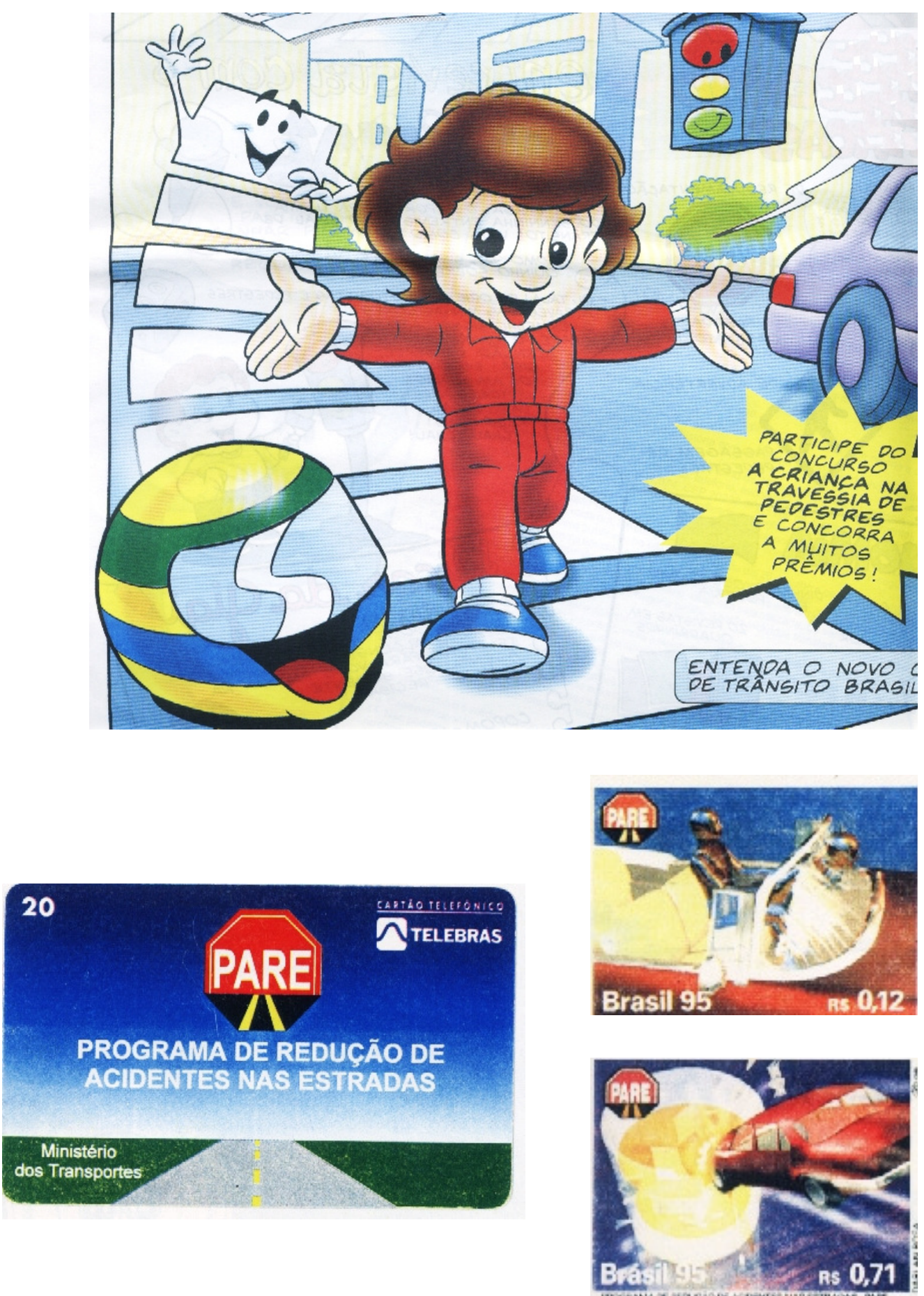

Materiais didáticos sobre trânsito produzidos pela União para as Escolas do Ensino Fundamental 
Ao longo dos anos o DENATRAN - Departamento Nacional de Trânsito produziu várias cartilhas orientando sobre direção defensiva, travessia de pedestres, etc. Este material era distribuído para os DETRANs - Departamentos Estaduais de Trânsito e outros organismos do Sistema Nacional de Trânsito que, por sua vez, repassavam ao usuário através de campanhas educativas. Foram poucas as vezes em que materiais específicos foram produzidos para serem utilizados nas Escolas, sob a orientação dos professores.

Uma destas raras vezes em que a União trabalhou diretamente com a Escola foi através do projeto "Rumo à Escola", cujos principais materiais didáticos produzidos apresentamos a seguir.

\section{Livro do Professor}

Este recurso didático utilizado pelo Projeto objetivou apresentar ao professor a filosofia base do Rumo à Escola e, ao mesmo tempo, introduzir conceitos diferenciados sobre trânsito, transversalização da matéria e dar orientações de como os professores poderiam introduzir o tema dentro de suas disciplinas específicas.

A proposta é a de que, fazendo a leitura deste livro o professor fosse capaz de:

1. Compreender a estrutura e os objetivos do Projeto Rumo à Escola;

2. Lançar um novo olhar ao trânsito;

3. Transversalizar o tema trânsito na disciplina que leciona;

4. Abordar o tema trânsito sob um novo enfoque;

5. Favorecer aprendizagens que conduzam seus alunos a uma visão ampla e abrangente sobre trânsito;

6. Utilizar diferentes recursos pedagógicos para desenvolver atividades relacionadas ao trânsito.

Em suma, a primeira parte do livro trata de informações sobre o Projeto Rumo à Escola, sua estrutura, como deve o professor proceder para estar sempre em sintonia, quais são os Órgãos Estaduais e Municipais parceiros e quais são os recursos materiais que serão disponibilizados para auxiliar o professor em seu trabalho. 
A segunda parte trabalha a concepção de trânsito contida no Projeto, sob o título “Trânsito e Educação Caminhando Juntos”. Discute informações sobre a atual Lei de Diretrizes e Bases da Educação Nacional e sobre os Parâmetros Curriculares Nacionais, além de apresentar exemplos da transversalização do tema trânsito na prática pedagógica do professor.

Por fim, na terceira parte, retrata textos de literatura, de jornais, de revistas, letras de músicas, referenciais bibliográficos e diversos outros recursos pedagógicos que proporcionem idéias para o trabalho em sala de aula. Busca mostrar ao professor que "Tudo é Trânsito".

A seguir, imagem representativa do "slogan" do Projeto Rumo à Escola e mapa com a localização dos Estados participantes.

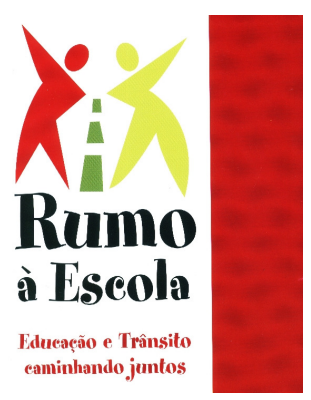

Estados abrangidos pelo projeto

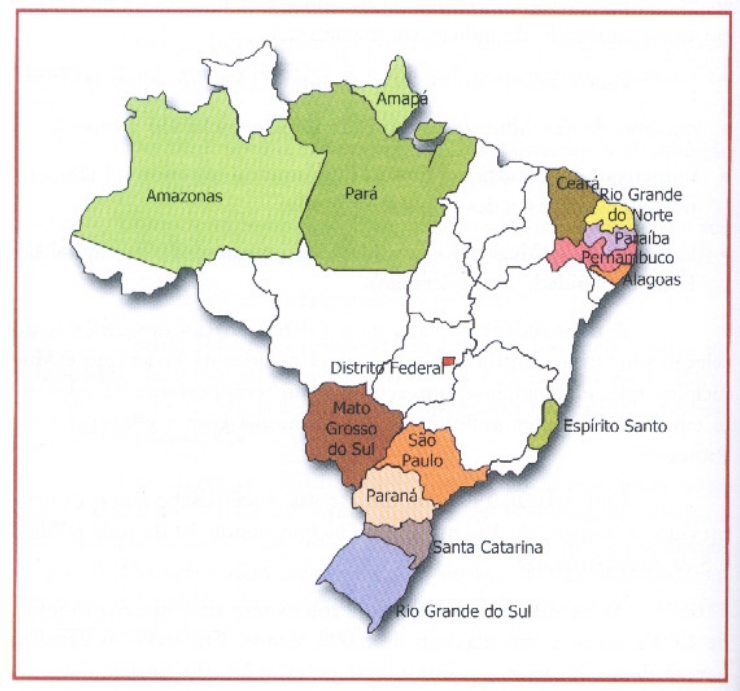




\section{Almanaque Rumo à Escola}

O Almanaque Rumo à Escola é uma revista bimensal que tem como principal finalidade proporcionar a trocar de experiências entre os professores das diversas escolas envolvidas com o Projeto. Através deste, trabalhos e atividades de professores e alunos são divulgados e chegam ao conhecimento dos demais leitores, estimulando a troca de idéias.

Além disso, o almanaque traz em seu contexto dicas e informações importantes sobre o trânsito.

Modelo da capa da edição 2 do Almanaque e algumas partes internas.






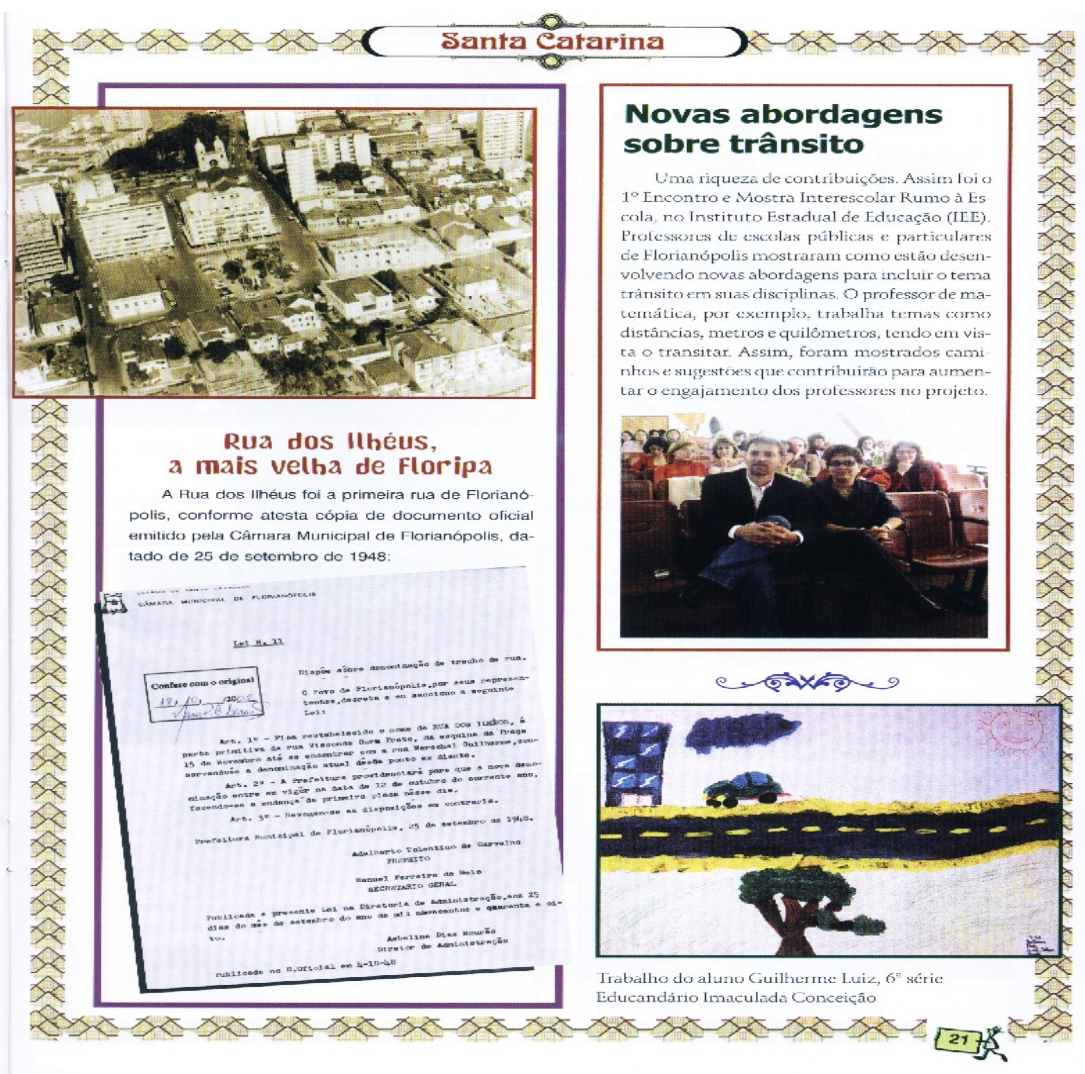









\section{Livros Paradidáticos}

Os livros paradidáticos são edições voltadas para os alunos, sendo um livro específico para cada série do ensino fundamental. Em geral, trazem dicas e orientações de trânsito para os alunos sempre se utilizando uma forma bastante lúdica e abordando o tema dentro da filosofia do Projeto, ou seja, o trânsito enquanto um espaço de locomoção e convívio social.

Segue imagem da capa de cada livro, por série.
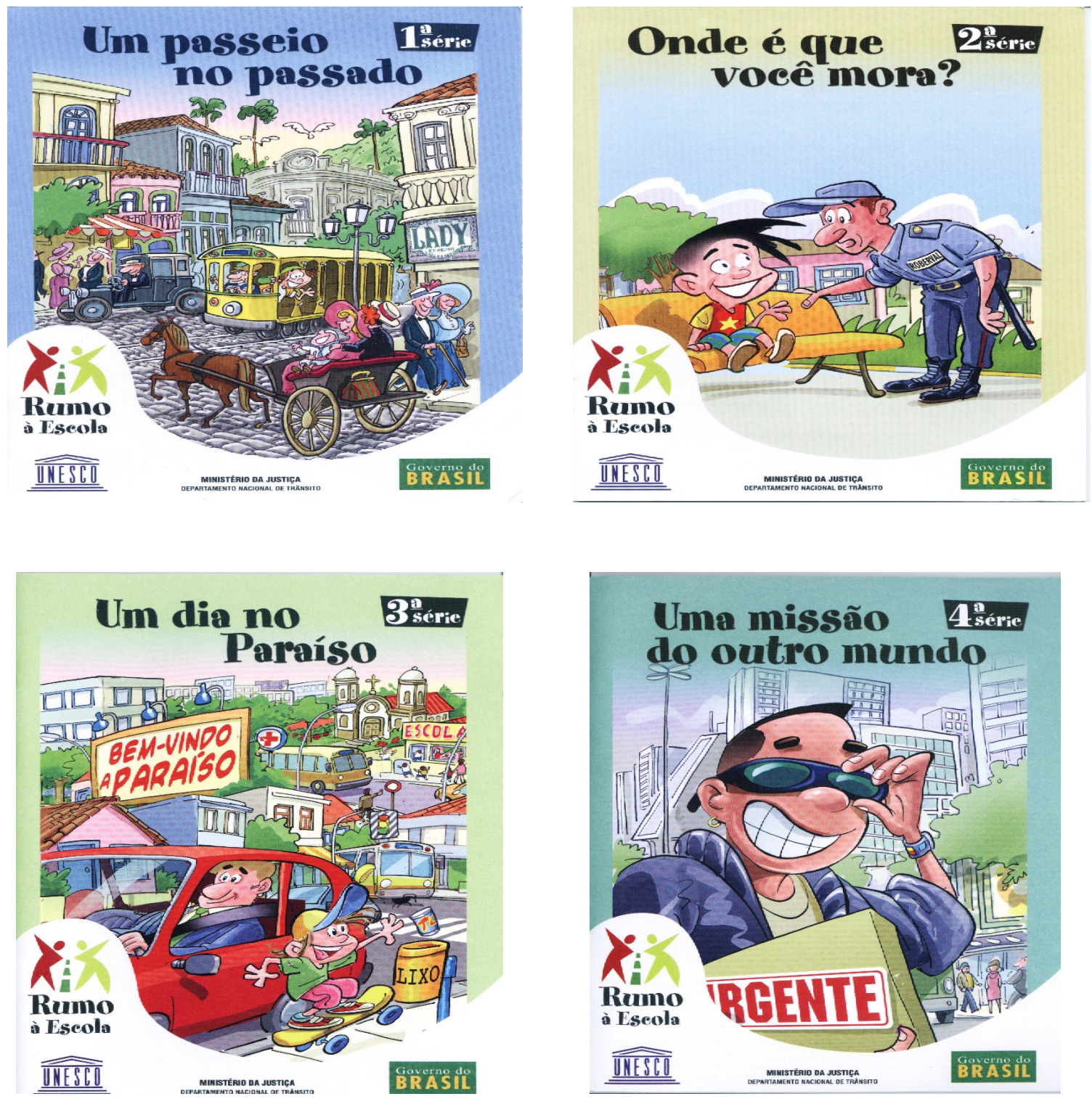

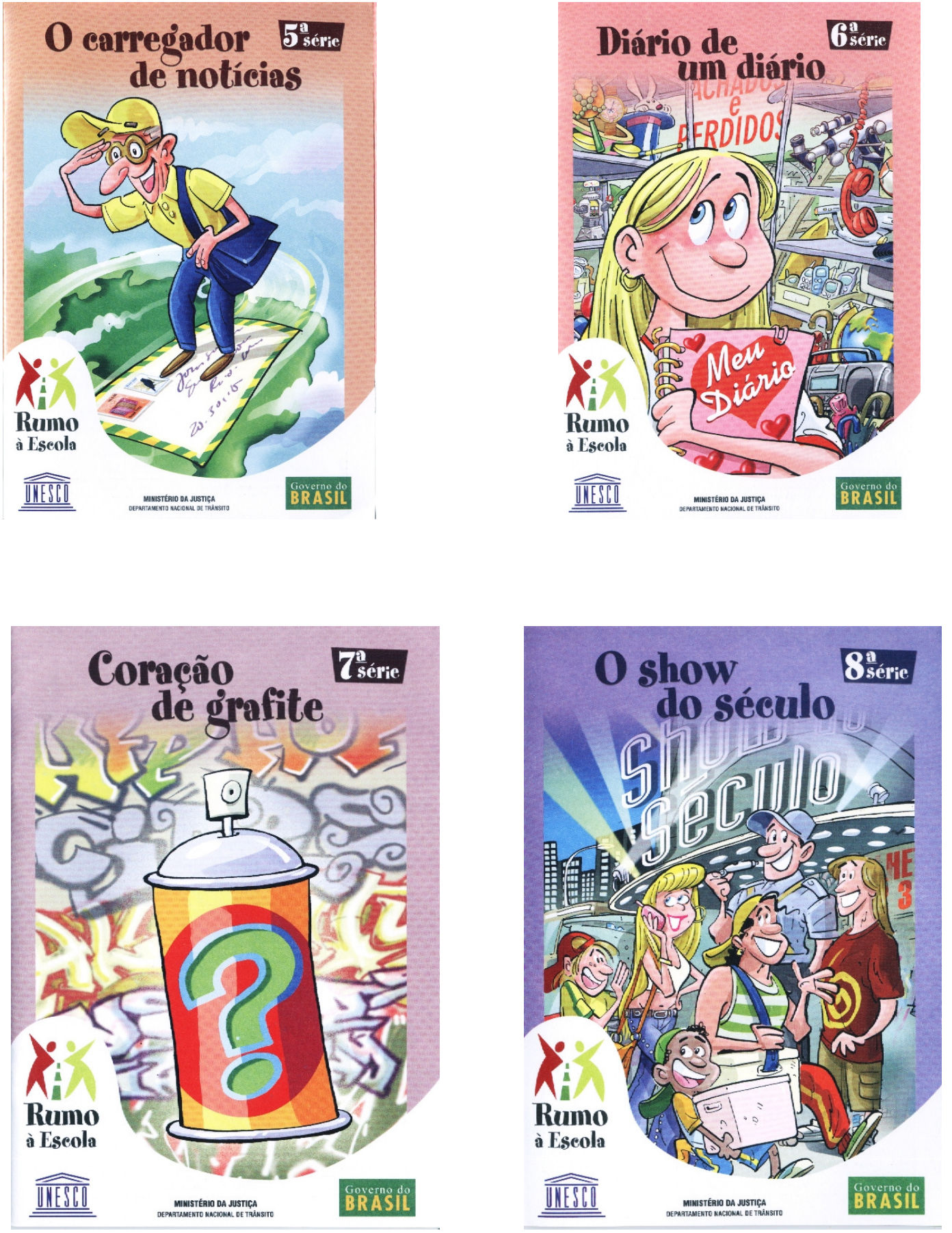


\section{Caixa Rumo à Escola: Transitando pelo Brasil}

Esta caixa traz um conjunto de diferentes recursos pedagógicos, abordando as mesmas temáticas.

Divididos em cinco temas, o material é composto por cinco fitas de videocassete; cinco apostilas com textos e sugestões de atividades dirigidas; 40 transparências com imagens relacionadas aos textos indicados nas apostilas; um folheto explicativo; e três cd-rooms contendo jogos educativos, sendo um para alunos de $1^{\mathrm{a}}$ a $4^{\mathrm{a}}$ séries - de pontinho em pontinho se faz um caminho, outro para alunos de $5^{\mathrm{a}}$ a $8^{\mathrm{a}}$ séries - transitando pelo Brasil e um de orientação aos professores.

O principal objetivo desses recursos pedagógicos é apresentar aos alunos do Ensino Fundamental as diferentes realidades do transitar em nosso país, utilizando cinco eixos temáticos:

1. Ir e Vir: Direito de Todos;

2. Meios de Locomoção;

3. O Jeito de Ser dos Lugares;

4. As Cidades;

5. Transitar é Conviver.

O pensamento é que, a partir das sugestões de atividades propostas, será possível transversalizar o trânsito na área disciplinar de cada professor de maneira mais criativa e prazerosa. Todos os eixos temáticos, acima descritos, apresentam enfoque na concepção adotada pelo Projeto Rumo à Escola, fundamentados nas palavras-chaves Locomoção, Comunicação e Convívio Social. 


\section{Caderno de Registro do Professor}

Partindo da consideração de que era difícil para o professor manter ordenado os registros das atividades, pertinentes ao Projeto, que o mesmo desenvolvia com os seus alunos, o Rumo à Escola elaborou e produziu um caderno de registro que foi encaminhado aos quase 20.000 professores participantes em todo o país.

Além de facilitar o registro dos professores, este caderno possibilita ao Projeto um acompanhamento mais próximo dos resultados obtidos pelos professores em sala de aula em relação às atividades desenvolvidas e a reação dos alunos. A proposta é de que, ao final de cada período letivo o caderno possa ser recolhido pelos técnicos dos Núcleos Regionais, substituído por outro, e encaminhado para análise ao Núcleo Central.

O caderno de registros contempla, em cada página, espaços para dicas de trânsito, trechos de texto ou músicas, sugestões de atividades e ainda traz, em diversas páginas, trabalhos desenvolvidos por alunos e professores das escolas participantes do Projeto.

Sem sombra de dúvidas, o Projeto Rumo à Escola se torna um marco para a questão da educação de trânsito no Ensino Fundamental implementada pela União.

Considerando as últimas três décadas, é a primeira vez que temos a oportunidade acompanhar um Projeto voltado para a educação nas escolas ser concebido com filosofia adequada às dimensões trabalhadas na rede escolar, apresentar um conjunto de materiais e recursos pedagógicos sempre na mesma linha filosófica e com excelente padrão de qualidade de produção e, acima de tudo, com todas as características de ser um Projeto contínuo.

Ao constituir equipe técnica nos Estados para fazer o acompanhamento e a orientação dos professores junto às escolas o Projeto rompeu com a tradicional mania dos organismos de trânsito de apenas distribuir materiais técnicos. Conseguiu avaliar, passo a passo, o processo de implementação e pôde sinalizar com as linhas de ampliação e ajustes do Projeto. 
O Rumo à Escola tinha em sua programação a produção de uma série de outros recursos pedagógicos de auxílio ao professor e ao aluno. Mantinha um Portal de trânsito para a intercomunicação e estudo entre os professores e equipes de trabalho - DENATRAN; realizou teleconferência sobre trânsito entre todos os quinze Estados; e programou a realização de vários cursos à distância para os professores.

Em relação à equipe de trabalho, realizava, a cada três meses, Encontros Técnicos de atualização, debate e avaliação do Projeto. Os Encontros ocorriam sempre em Brasília, tendo sido feitos cinco até novembro de 2002.

No ano de 2008 foi implementado pelo Denatran o Projeto "Trânsito Consciente", série com vídeos e recursos educativos voltados para o público adolescente.

No ano de 2009 o Projeto "Viva o Trânsito", com a produção de recursos didáticos distribuídos para as escolas do ensino fundamental dos municípios integrados ao Sistema Nacional de Trânsito.

Destaca-se ainda as ações desenvolvidas pelo Denatran, durante o ano de 2008 e 2009, relativas a cursos de treinamento básico para os profissionais da área de trânsito que atuam diretamente dentro dos órgãos oficiais ou prestam serviços credenciados por estes. Dentre os cursos cita-se: Curso Básico de Trânsito; Legislação de Trânsito; Educação para o Trânsito; Requalificação Didática dos Instrutores de Centros de Formação de Condutores; Análise de Recursos de Infração de Trânsito; e, Gestão de Trânsito. 